Portland State University

PDXScholar

Spring 6-2-2015

\title{
STEM Education in the Foreign Language Classroom with Special Attention to the L2 German Classroom
}

Sarah Danielle Schoettler

Portland State University

Follow this and additional works at: https://pdxscholar.library.pdx.edu/open_access_etds

Part of the Bilingual, Multilingual, and Multicultural Education Commons, German Language and Literature Commons, and the Science and Mathematics Education Commons Let us know how access to this document benefits you.

\section{Recommended Citation}

Schoettler, Sarah Danielle, "STEM Education in the Foreign Language Classroom with Special Attention to the L2 German Classroom" (2015). Dissertations and Theses. Paper 2313.

https://doi.org/10.15760/etd.2310

This Thesis is brought to you for free and open access. It has been accepted for inclusion in Dissertations and Theses by an authorized administrator of PDXScholar. Please contact us if we can make this document more accessible: pdxscholar@pdx.edu. 
STEM Education in the Foreign Language Classroom with Special Attention to the L2

\title{
German Classroom
}

by

Sarah Danielle Schoettler

A thesis submitted in Partial fulfillment of the requirements for the degree of

\author{
Master of Arts \\ in \\ German
}

\section{Thesis Committee:}

William B. Fischer, Chair

Kathleen A. Godfrey

Eva Thanheiser

Portland State University

2015 
() 2015 Sarah Danielle Schoettler 


\begin{abstract}
This thesis tackles the severed relocated and complex issues of foreign language education, with special attention to German as a foreign language, and of STEM education in the K-12, and in some cases K-16, educational system. After exploring the societal and national need for improved STEM and foreign language education programs, the thesis suggests methods of integrating STEM education elements and principles in the foreign language classroom. These methods are provided in chapters about integrating state and national education standards in the STEM fields; core academic subject fields and foreign language teaching; and finally in chapters about the most appropriate and effective pedagogies for successful STEM and foreign language integration. The thesis brings together research about such integration in learning modules and discusses assessment methods, and points toward areas of research. The learning modules and research seek to answer a need to shift education in the direction of an integrative, interdisciplinary approach that supports deeper learning, purpose for student learning, and student interest.
\end{abstract}




\section{Acknowledgments}

This a study was conducted and funded in part with the information compiled for the AATG STEM Articulation Grant and is meant to accompany the website created as a resource for German teachers wishing to integrate STEM education elements in their

classroom. I would like to express my deep gratitude to Professor William B. Fischer, receiver of and project supervisor for the grant, for his support, patience, and enthusiasm while I conducted this research. I would also like to thank Professor Eva Thanheiser and Professor Godfrey for their support, enthusiasm, and effort as part of this thesis committee. I am particularly grateful for the assistance given by Daniel, Lorrie, Zach, and Cody for their peer support and editing. I would like to offer my special thanks to the Portland State University Writing Center for being available for students in need of writing assistance, and the Podrabsky lab for providing PowerPoint slides and information for one of the learning module about the life of a Killifish. 
Table of Contents:

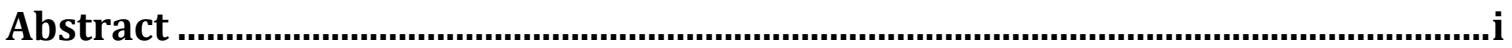

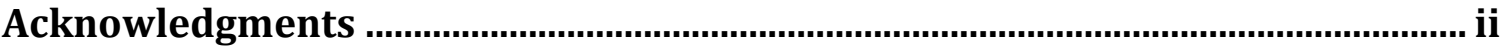

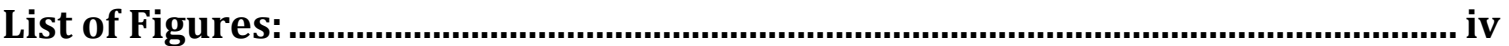

Part 1: A History and Introduction to STEM Education and Foreign Language

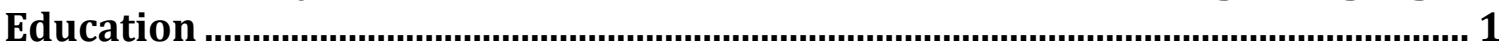

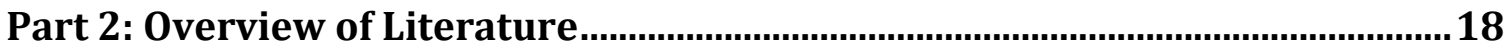

Part 3: Examples of Instruction, Curricula and Programs .......................................25

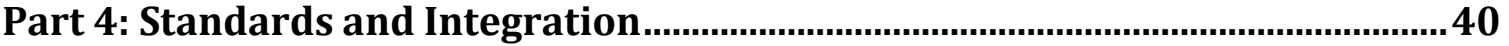

Part 5: Teaching Methods for Combining STEM Education and Foreign

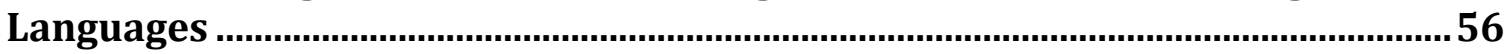

Part 7: Assessing Students' STEM + German performance ...................................86

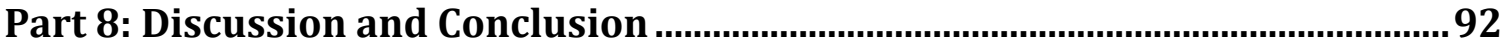

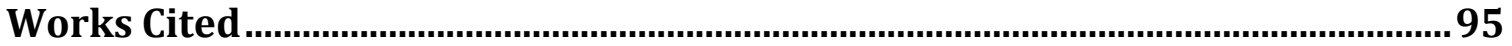

Appendix A: STEM + German Module, Das Leben eines Killifischs..................... 101

Appendix B: STEM + German Activity, Fahren! ................................................ 112

Appendix C: STEM + German Module, Energiequellen ....................................... 121 
List of Figures:

Figure 1: ACTFL Proficiency Guidlines Rating Scale 51 


\section{Part 1: A History and Introduction to STEM Education and Foreign Language Education}

This paper discusses an innovative contribution to STEM (Science, Technology, Engineering, and Mathematics) education and Foreign Language education and discusses the national need for such an interdisciplinary education. The research and discussion presented here aims to encourage integrated interdisciplinary studies between German and other foreign language fields with the STEM subjects by reviewing current STEM Education literature and programs; current foreign language programs; pedagogy relating to the integration of the subjects; and any effort to combine the two content areas. This integration will serve as an innovative suggestion to improve the STEM career and curriculum crisis as well as speak to the need to preserve and reinvigorate German Studies in the Unites States, as well as other language programs in the K-16 educational system.

Problems with low enrollment and lack of enthusiasm in STEM subjects and second language courses are nothing new to education in the United States. Since the Cold War era and the launch of the Soviet space satellite Sputnik, initiatives have been made to increase enrollment in language, science, and math education in order to keep or regain - US global leadership in the STEM fields. Within recent years a call has arisen for an interdisciplinary focus within the STEM subjects themselves and for the integration of other academic subjects. Because of the need for subject integration, stakeholder efforts have been exerted to improve enrollment, enthusiasm, and pursuit of careers that fall in the STEM categories. For their part, foreign language education 
departments are experiencing severe problems with enrollment, low enrollment especially in German programs and high enrollment in Spanish. This requires innovative solutions that address student interests, purpose, and academic or career relevancy.

Before teachers can apply innovative solutions to these issues mentioned, they must first understand the current state of STEM and foreign language education and curricula in the United States, as well as their importance to society. For example, this "buzzword" (Breiner, Harkness, Johnson, and Koehler 3) is not as clear to stakeholders, academia and the general public as STEM educators would like the acronym to be. STEM has multiple meanings and the inclusion of the "TE" (Technology and Engineering) fields is a relatively new addition to the educational initiative familiarity (White 5). The "TE" fields are not traditionally distinct fields of study and current examples of Technology and Engineering programs are not clearly defined; however, these disciplines are at the heart of STEM education because they bring together content knowledge with - to use some other current 'buzzwords' - problem-solving, real world, $21^{\text {st }}$ century skills. In "TE” classrooms students learn to create, use, and design tools using concepts from the science and mathematics disciplines.

Similar to the "TE" of STEM education, foreign language education is still somewhat of a mystery to the general public, and has actually undergone numerous revisions since it adopted the Grammar-Translation method applied to learning Latin and other languages worldwide in the $19^{\text {th }}$ century (Richards and Rodgers 3-5). Foreign language education, at least when conceived and practiced in a modern way, focuses more on learning the language for communicative real-world purposes, as opposed to 
focusing on literature or grammar in the target language. One can see the connection between these initiatives as they aim toward a more practical and applicable use of the skills and knowledge in these content areas. Both foreign language education and STEM education have mysteries, yet with proper clarification the general public can understand their value.

Both fields in academia need attention to their curricula and application in the learning environment and in the real world because they are both valuable to the nation's global status and students' learning experience. Beyond that- and a matter of even greater controversy and "mystery" to the general public - is the combination of STEM education and Language education. The integration of these subjects may seem difficult and offputting to academia, the general public, and stakeholders (parents, funders, etc.), because of the misunderstanding about how they would be integrated and how people learn. In order for the stakeholders to understand the nature of integration involved and how to apply STEM education in the foreign language classroom, educators and developers must undertake the following tasks: STEM and foreign language education must be clearly defined for academia and the public to understand; the teaching methods behind integrative learning and language learning must be made available to educators through professional development; and the necessary teaching materials and resources must be found, adapted, or created for classroom supplemental use. This paper addresses these three issues that support an educated public, who function in a global economy with the skills STEM education supports and the use of foreign languages as a tool to communicate in a variety of situations. 
The history or both foreign language education and STEM education plays a large role in their current status and understanding. After the Cold-War era, STEM, science, and mathematics received much of attention financially and academically. Producing students with STEM related careers was - and still is - suggested to be a potential solution to the US's threatened global standing (Wissehr, Concannon and Barrow 374). Events like Russia's success in landing on the moon before the US hurt its esteem, and the desire to increase in STEM careers, students, and accomplishments was a goal that would improve the US's global status. The history of the US government's motivation behind funding STEM education and teachers starts mainly with the "red moon" (Wissehr, Concannon and Barrow 369), or Sputnik, orbiting the Earth, and the US defending its pride as a leading, innovative, global power in the 1950s and 1960s. Actually the US was already leading in numerous areas of technology and invention, but Russia had beaten the US in launching the first satellite into space (Wissehr, Concannon and Barrow 369). As a result of the crisis in the US's national pride, something had to be done to enhance science education and improve the US's status in scientific innovation and global competition.

In 1958 congress passed the "National Defense Education Act" (NDEA) to improve education in the United States during the Cold War conflict. The NDEA's goals were to create scientists who would put the US back on top of global competition by improving the quality of science and math programs in K-12 education (Wissehr, Concannon \& Barrow 369). The state of science education was very poor when the NDEA was signed into law. For example, there was a shortage of qualified professors 
and teachers with degrees in sciences (Wissehr, Concannon \& Barrow 371-372). As a result, US schools and universities were deteriorating, creating a situation where the US was not fit to properly compete with other countries like Russia (Simkovic 549); therefore, the US needed this educational reform to compete with new, growing, global powers.

Science education in the US was lightweight compared to the Soviet Union where the school day and year were longer, and chemistry and physics were fundamental subjects in schools (Wissehr, Concannon and Barrow 372). Naturally something needed to be done to improve education in the US. As a result of the NDEA's initiatives and overall national interests in the sciences at the time of Sputnik, the "golden age of science education" began (Wissehr, Concannon and Barrow 374). This "golden age" describes the improvements and funding made in teacher choice, curriculum, and research, all in science and mathematics. The result of the positive effects of Sputnik on the US educational system was the creation of "National Science Education Standards and Benchmarks for Science Literacy" to help improve the quality of science education in addition to the overall state standards that connect all subject areas (Wissehr, Concannon and Barrow 374).

More than half a century later our nation is struggling again with the education of students looking to pursue STEM related careers. The US found new global competition in India and China (Sanders 20), which led to the production of the 2007 repost "Rising Above the Gathering Storm: Energizing and Employing America for a Brighter Economic Future" report. This new report, compiled by the National Academies 
(consisting of the National Academy of Sciences, National Academy of Engineering, Institute of Medicine and National Research council), called for another revision to the science education curricula in the US and deals with similar problems in education, including the training of educators, effectiveness of programs, and promotion of diversity in the STEM subject professions (Bybee 996). However, after this 2007 report, a response and second report was compiled in 2010 by the National Academies in "Rising above the Gathering Storm, Revisited." This document revealed little to no improvement in STEM career and education (National Research Council 4). It recommended providing more scholarships for teachers in order to produce more qualified teachers, increased funding for research, and improve learning conditions for students (National Research Council "rising above" 19-22). Whereas these reports state the need for improved curricula in all educational subjects, with emphasis on mathematics and the sciences, they do not directly tackle the subject of STEM education. For a definition of improvement to STEM subjects and STEM education, it is necessary to turn to the educators involved in the reform.

It is not clear to many what the STEM acronym means and it is even less clear what STEM education implies in the new millennium. The New York Times published an article explaining that the acronym "stands for Science, Technology, Engineering and Mathematics, supposedly the major food groups of comprehensive science education" (Angier, par. 3). The article also mentions the misunderstandings and misinterpretations of the acronym. For example, it refers to the acronym's "too-cute reference to botany" (Angier, par. 6) and that the general public mistakenly relates STEM to "stem cells, 
branches, leaves and broccoli stems" (par. 10). All of these assumptions are, however, much better than assumptions and misunderstandings created by the original SMET acronym for science, mathematics, engineering and technology that the National Science Foundation made in the 1990s. SMET ended up sounding too much like "smut" (Sanders 20). Another issue arises specifically with the " $T$ " or Technology in STEM education, which is often mistaken for computing and computer literacy (Sanders 20). Technology in STEM refers to "technological literacy for all" (Sanders 24), technological design, and the integration of the other science, engineering, and mathematical aspects of creating and understanding technology. According to the Technology for All Americans Project, and International Technology Education Association, technology is defined as humancreated "tools, machines, and systems" that help human activities through "devices, capabilities, and knowledge" (ix). Aside from the confusion associated with the acronym, it is this very integration of all the STEM subjects seen in Technology and Engineering education that creates good examples of STEM education today.

"Rising above the Gathering Storm, Revisited" raised awareness of the status of education in the US and its global standing. In addition to this report, the President's Council of Advisors on Science and Technology provided ideas for improvement (Angier, par. 5). Some educational institutions are acting on the suggestions, as they realize that the current educational system has not greatly improved since the "golden age of education." However, overall education in the US is still lacking in preparing students for the post-k-12 workforce and/or higher education. STEM education today is loosely defined as the integration of the STEM subjects as one "cohesive entity" (Breiner, 
Harkness, Johnson, \& Koehler 3). This educational movement seeks to remove the "educational silos," or the independent disciplines taught as content courses, that the STEM subjects have been divided (White 5). For example, a STEM educator would integrate two or more STEM subjects or STEM with other academic subjects (Sanders 21) in order to demonstrate real world application (Breiner, Harkness, Johnson, \& Koehler 3), stimulate authentic inquiry (Sanders 21) and promote critical thinking (White 2). STEM education curricula seek to simulate new learning experiences that improve upon an educational system and teaching methods that were created in the late $19^{\text {th }}$ century, which pays little attention the discoveries made about how people learn and new technologies, and combine the educational "silos," meaning disciplinary learning, for a deeper learning experience. This trend, as I will discuss in detail shortly, is similar to the adoption of communicative language teaching methods, which also departed from older, less effective teaching methods from the $19^{\text {th }}$ century and earlier.

The STEM education movement seeks not only to produce a new workforce of highly educated and trained individuals within the STEM fields, it also intends to produce individuals with $21^{\text {st }}$ century skills. A quotation from What is STEM education? (Bybee 996) outlines the necessity for this type of education and why it is so important for the production of a quality workforce:

"As stressed in the National Academies report 'Rising Above the Gathering Storm,' students must acquire such skills as adaptability, complex communication, social skills, nonroutine problem solving, self-management, and systems thinking to compete in the modern economy. To the degree that STEM 
curricula incorporate group activities, laboratory investigations, and projects, they afford the opportunity for students to develop these essential 21 st-century skills and prepare them to become citizens who are better able to make decisions about personal health, energy efficiency, environmental quality, resource use, and national security. Indeed, the competencies that citizens need to understand and address such issues, from the personal to global perspectives, are as clearly linked to knowledge in the STEM disciplines as they are to economics, politics, and cultural values.” (Bybee 996)

This quote outlines clearly the value of STEM education, its real world application, and the quality of learners it produces. STEM education is not simply to educate about the specific fields, but about functioning and problem solving in the real world.

As part of STEM education and educational reform in the US, the various National Academies and individual educators see the value of STEM and its relation to other fields. STEM education combines the content of the traditionally separate disciplines to encourage deeper learning. But other programs promote integration even further and generate still other acronyms. STEAM is created to involve the arts in STEM education, which further integrates other programs. The language arts programs integrate the STEM disciplines into their curriculum, lessons, and/or activities. An additional acronym is STREAM, which involves adding " $\mathrm{R}$ " for reading as another letter. One potential addition to this interdisciplinary focus, using STEAM and other inclusive educational programs and initiatives as examples, is the integration of STEM in the foreign language classroom, specifically with the L2 German classroom in k-16 
education, and especially secondary education in grades 9-12, with low level language proficiencies. The interdisciplinary shift in education shows that there are issues within the US's educational infrastructures; however, it does show a great effort to improve and integrate all subjects for better learning.

What additionally has become an acute issue in the US, with less of a solution, is foreign language education (Altschuler, par. 5). Foreign language education has a rich history, has great societal value, and has gone through many reforms like science, math and STEM education; however, there is less of a perceived need for foreign languages in the US due to the frequency and quality of English language programs abroad and the frequency of English spoken in non-US countries as a second and business language (Panetta 6). But foreign language in US schools has value in teaching students language not only to develop critical thinking skills, but also to expose students to different cultures and ways of living, which can later become a communication skill in various interactions in the professional world and out.

The history of foreign language education in the US is similar to that of STEM education, although Foreign Language education has never had the political and social support that STEM has. Again the World Wars, lack of funding, and perceived necessity create issues with the quality, value, and availability of foreign language programs in the US. In a paper presented at the Stanford Language Center, Leon Panetta, former US Secretary of Defense, questioned the United State's value of foreign languages and foreign language education and outlined issues with foreign language education in the US since the beginning of the $20^{\text {th }}$ century. In his paper "Foreign Language Education: If 
'Scandalous in the 20th Century, What Will it be in the 21st Century?" Panetta discusses the decline of foreign language education in the US at the turn of the century due to the xenophobia that arose from World War I and US imperialism (3).

The perceived value of foreign language education in the US has diminished; especially in German as a foreign language with French and Spanish also falling shortly behind as statistics show (Ecke 64). Language education is still a graduation requirement in some high schools to graduate and it is a requirement for attending most four-year college and universities; however, other than fulfilling a requirement, most students, administrators, parents, and other stakeholders other than the foreign language educator community, see little value in teaching foreign languages. One way to revive foreign language education and interest in foreign language study is to involve it in the STEM crisis by providing teachers with high quality materials for STEM in the foreign language classroom. This paper will focus on the German and other foreign language classrooms and offer information on how and why STEM should be involved in the classroom and how and why STEM education can help with German and other foreign language programs.

It was not until World War II and the US's communicative disadvantage abroad in foreign languages that the obvious need and value of language education was discussed (Panetta 3). During this time the Army Language Method was developed and adapted to assist troops abroad. This method was later adapted for use in schools and colleges after the creation of the NDEA, which also called for reforms in mathematics and STEM education as previously discussed. Similarly, after WWII and the Korean 
War, the shock of the Sputnik launch sparked national interest in foreign language study; specifically in Russian due to the origin of Sputnik, but the interest extended to other languages at schools and universities (Panetta 9). Educational reforms created by national need are the main encouragements in the survival and quality of both STEM educational programs and foreign language programs; however, foreign language programs are currently lagging behind STEM education in quality, perceived necessity, and funding. This is because the US views foreign language capabilities as a secondary skill, US corporations invest in English instruction abroad, and English is widely used to communicate in the business world (Panetta 10). If the US is expecting to remain a leading global power, the quality and national value of foreign language education must improve.

Just like the standard of science and mathematics education, the quality of language education has improved somewhat since 1958. This quality has improved through learner-centered teaching methods and progressive pedagogical practices. The first set of Proficiency Guidelines, which greatly impacted foreign language education and structure (Liskin \& Gasparro 483), were published in 1982 by the American Council on The Teaching of Foreign Languages and foreign languages expanded to some elementary schools. The development of the Proficiency Guidelines has had a significant impact on language education because they defined language use through "function, content and accuracy" (Higgs 5) at different levels rather than, according to Higgs, neutral descriptions of grammar and vocabulary as goals for learning solely in themselves. Through this definition of different levels of capabilities in linguistic 
function, content, and accuracy, a foreign language program can be structured around the varying capabilities of the second-language speaker. The Proficiency Guidelines and structure they create is considered to be the "organizing principle" of language instruction, method, material and curricula (Higgs 4-7).

The Proficiency Guidelines, as I will discuss in part 4 of this thesis, define what a second-language learner can do ranging from the novice learner (little to no linguistic capability in the second language) to the distinguished learner (someone that is completely competent in the second language) in "real life contexts" and cover speaking, listening, reading, writing and culture in and of the target language (Higgs 12). These levels of proficiency create examples of competency in the foreign language in which a curriculum can be formed.

The development of the ACTFL Proficiency Guidelines was a result of the need for a National Criteria and Assessment Program, which would use proficiency as goals for achievement and assessment in both students and teachers (Higgs 30). This initiative was also sparked after the NDEA and the apparent need for better foreign language programs and education in the United States.

Although the NDEA, which later became the Higher Education Act (Panetta 9), led to the support of improved language programs and classrooms, the teaching of foreign languages "ebbed and flowed depending on perceived national need" (Panetta 4). This is again the case today as businesses are unable to communicate in the languages of other nations, at least not without the help of native speakers of the target-business languages. US companies must rely on foreign countries' language programs in English or fund 
programs that teach English abroad if they wish to communicate effectively in English in the workplace. If foreign language and intercultural education is not fostered, US companies must accept that the US is not in control of its own resources due to the lack of communication or ability to communicate in the target language of a foreign culture (Panetta 6). Panetta uses the term linguistic capital to describe a foreign nation's ability to use its linguistic abilities to "negotiate economic advantages for themselves" (Panetta 7). With the US lacking in linguistic capital due to disappointing progress in domestic foreign language education, the size of a trained, prepared and capable workforce is significantly smaller than other nations (Panetta 7).

The situation of foreign language education in the US has not significantly improved since the Cold War; however, there have been some positive improvements as discussed above in the US and in overall, worldwide language instruction. Language pedagogy has changed significantly since the $19^{\text {th }}$ century, due to involving many reforms as teachers and researchers discover more about how people learn languages. More research about second language acquisition and learning styles has led language pedagogy away from the traditional grammar-translation method to a communicative approach (Brandl 1). Communicative-Language-Teaching (CLT) has no specific method, in fact is it said to be "post-method" instruction, which combines other methods to support using the language for communication (Brandl 1). That is, CLT is based on the understanding that languages are used as a tool to communicate in real-life situations (Brandl 5). This idea functions as an "organizing principle" for foreign language programs through the Proficiency Guidelines. CLT focuses on meaning making in the 
foreign language in all of its forms: written, spoken, and aural, as opposed to the explicit instruction of structures, vocabulary, and forms - or, as I will discuss in chapter part 5, language learning. Language education, like STEM, mathematics and science education, has undergone a number of reforms to provide improved education for students in the $21^{\text {st }}$ century. Both are reflecting on previous less student-centered classrooms and teaching methods by reacting to modern research and changes in demand.

Foreign language education has struggled to remain a core subject in US classrooms. L2 German classrooms are consistently losing students and programs. A study published in 2010 noted that enrollment in German and the number of German language programs in the US has significantly diminished (Ecke 60-61). This study was an alarm among teachers because teaching positions are still in demand, despite the low enrollment in German programs, and with new, motivated and innovative teachers, a solution could be found for saving German programs in the US (Ecke 74). There are more part-time positions in German-teaching available as posted on the American Association of Teachers of German's webpage, while full-time positions are diminishing as well as German programs in General (Ecke 71-74). The statistics in this article about the loss of programs and enrollment in the US were disheartening, but the call for teachers was an encouraging note because it shows German programs still exist and German faculty are still in demand, even at the part-time level. Ecke states that proper teacher training and qualification is a problem in the field, even though the teachers are still in demand (75). 
Aside from only part-time work and underqualified workforce, another issue is of the importance of student interest, motivation and enthusiasm in the student's choice to study German (Ecke 56). The majority of students studying German at the introductory level are students who have some connection to German by way of ancestry, background and/or previous exposure to German (Ecke 56). German heritage is not enough to sustain German programs because the number of German-speaking households is diminishing (Ecke 56), although the hereditary interest still remains. German programs need more qualified teachers and a motivation other than previous interest in the subject. German studies and language programs need to have real world value and application much like the STEM subjects in modern education, and with the change in content a change in methods. The fields need to be revamped and integrated to serve global, national and personal interest in order to help serve students in their education and careers.

The integration of German + STEM education will be beneficial not only to the students and their stakeholders, but also to the quality of education in the US and the global position of the US. Students will not learn a second or foreign language and the STEM subjects in the STEM subjects' respective educational silos; the subjects will be integrated and given purpose to students' everyday lives and goals which will produce capable citizens with $21^{\text {st }}$ century skills that are ready to compete in a global community.

The following chapters will outline current STEM education and STEM + Foreign Languages programs; current standards to fields relevant to combining STEM + Foreign Languages; teaching methods, assessment, and lesson plans for integrating the subjects. The materials, examples, and instructions within the upcoming sections can all 
be applied to curricula, lessons, activities, instruction, and teaching methods that apply to combining STEM education + Foreign Languages. 


\section{Part 2: Overview of Literature}

STEM education is a fairly new educational initiative to help with issues of enrollment, outcomes and curriculum in science, technology, engineering, and mathematics programs. Foreign language education, similarly, is regarded as necessary for the nation to succeed in producing $21^{\text {st }}$ century skilled workers who can compete globally. STEM education combines the four fields, science, technology, education and mathematics, to create an integrative approach to learning for students to grasp a deeper understanding of science and math concepts through real-world, hands-on experiences. Although the acronym STEM is used to refer to a new innovative method for teaching science and math, the data to support its success are scarce and difficult to find, as is concrete literature surrounding methods, application, and curriculum. Information about the integration of other academic subjects, more specifically foreign languages, is even more difficult to find, no doubt due to the lack of programs and research in this area. Similarly literature about the application of methods in STEM education relating to the individual STEM subjects and other academic subjects is scarce, although information about the need for STEM education and a reform of science and mathematics education is widely available. Through specific search terms and bibliographical references, the background research for this thesis yielded a fairly useful series of primary and secondary sources that relate to the teaching, structure, research, application, success of and need for STEM education and foreign language education in the US, and literature about the combination of STEM education with other non-STEM subjects which can be related to the integration of STEM in foreign language education. 
The body of literature pertaining to STEM education and foreign language education can be divided into the following categories: 1) first, literature addressing the need for innovative teaching solutions that will support $21^{\text {st }}$ century skills and improve the Unites State's global status; 2) second literature consists of current programs and initiatives that have adapted the suggested reforms; 3) third are sources that support the material in the first two initiatives; 4) fourth are the articles from online and paper newspapers and editorials about STEM education. Literature relating to the first category is mainly available in educational and government reports, legislation, or initiatives stating or creating the need for educational reforms in the US. Examples of the third section of literature are primary and secondary sources about pedagogy and teaching methods or documents about educational standards, and resources outlining the history of STEM education or foreign/German language education. The body of literature attempting to combine STEM education and foreign/German language education supports the need for the integration of the subjects, but does not present a solution to integration.

The first section of literature relating to the need for educational reforms in the US relates to the National Defense Education Act, which expresses the need for better science, math and foreign language education during the Cold War conflict. Sources describing these needs are found in more recent legislation, reports, and initiatives. For example, an expression of the need for educational reform can be found in the report Rising Above the Gathering Storm: Energizing and Employing America for a Brighter Economic Future (2007) and then again in Rising Above the Gathering Storm, Revisited: 
Rapidly Approaching Category 5 (2010). These both are more recent publications by the National Academies, a collaboration of various national organizations. The National Academies address the need for improved education in the US; they highlight once again, the STEM fields and the need for students trained in foreign languages so that the US can remain competitive in the $21^{\text {st }}$ century. All three of these documents have laid out suggestions for improvement.

Further examples of this first literature group includes a report published during the same year the "Rising Above the Gathering Storm, Revisited: Rapidly Approaching Category 5" (2001) was published. The National Science Board, which consists of advisors on science and engineering education policy (National Science Board, 2013), produced and published a report titled "Preparing the Next Generation of STEM Innovators: Identifying and Developing Our Nation's Human Capital” (2010). This report outlines the history of the need for improvement in the STEM education fields and provides a number of recommendations for improvement. The National Academies produced a similar report titled "STEM Integration in K-12 Education: Status, Prospects, and an Agenda for Research" in 2014 as a response to the report "Monitoring Progress Toward Successful K-12 STEM Education: A Nation Advancing?” in 2013. The 2014 report described the framework of current integrative STEM education programs, initiatives and curricula in the United States and called for more research and collaboration in STEM education. These documents, including reports and legislation as seen in the previous examples, outline the national need for reform in the educational system in the US. They highlight the need for improved instruction in STEM fields 
through new methods of STEM education and highly qualified teachers. The documents also mention the national need for foreign language education as part of $21^{\text {st }}$ century skills. This body of literature supports the need for innovation, integration, and improvement.

The second category of literature observed in this thesis are newspaper articles and editorials about the understanding of STEM education, programs describing the STEM education curriculum they have created, the need for STEM education and foreign language education, and the integration of STEM fields with other academic subject classrooms. These are more commentaries from the public and professionals in the field. For example, the article "STEM, STEM Education, STEMmania" discussed the nature of STEM education, the issue of communication between educators, stakeholders, and the history of STEM education initiatives in order to introduce the graduate program in STEM education at Virginia Tech (Sanders 21). This article describes an example of a professional development program created to support teachers wishing to become STEM educators. The article outlines the nature of the program and how it relates to the history and goals of STEM education. Other examples of program descriptions are the articles titled "Making STEM Real” (Hoachlander \& Yanofsky) and "STEM progress in Katrina's wake" (Gonzalez), which discuss programs in California and Louisiana and touch on the definition of STEM education as related to their programs. Hoachlander and Yanofsky discuss the Linked Learning option for students in some California classrooms in their article "Making STEM Real" (61). They discuss engineering courses offered in some California high schools that allow students to integrate mathematics, science and 
other core subjects of their choice to focus their high school education around engineering and related fields (Hoachlander \& Yanofsky 63). This article explains the teacher resources involved in the classroom, how the Linked Learning exemplifies excellent STEM and interdisciplinary education, and how the program prepares students for their future after high school. "Making STEM Real" (Hoachlander and Yanofsky) mentions not only the inclusion of core academic subjects in the engineering classrooms, but also how their foreign language classes might include themes from the STEM focused engineering classroom. "STEM progress in Katrina's wake” (Gonzalez) discusses the implementation of new "progressive educational program[s] like STEMbased education" (Gonzalez 24) in the public schools of New Orleans. This article also discusses the nature of implementation and teacher supports. These resources serve as examples of current programs and efforts to encourage STEM education and their success.

The third section of literature reviewed in this thesis relates to the commentaries and supporting materials of the subject. The category of commentaries refers to the newspaper articles discussing the present nature of STEM education and reviewing certain programs. For example, the article titled "STEM Education Has Little to Do With Flowers" commented on the understanding of STEM education with supporting surveys and statements from experts. Other commentaries are the book The Tongue Tied American: Confronting the Foreign Language Crisis (1988) discussing the United State's lack of foreign language skills and Leon Panetta's speech (1999) given at a conference titled "The Study of Foreign Languages in the New Century: Retrospective Views from 
'The President's Commission on Foreign Language and International Studies' and Prospects for the Future" (Manuel, par. 5) on the state of foreign language education and study in the United States.

The final supporting literature is that on teaching methods, pedagogy, and educational standards for the content. ${ }^{1}$ These sources apply to the application and creation of STEM + German/foreign language activities, learning modules, and curriculum. The educational standards that can be used as a framework for goals and outcomes of STEM education and German/foreign language education and those discussed in this paper are the "Standards for Foreign Language Learning, ACTFL Proficiency Guidelines" (2012), "Common Core State Standards" (2010), "Next Generation Science Standards" (2012), and "Standards for Technological Literacy: Content for the Study of Technology" (2000). In addition to the standards that help create the goals and outcomes of such programs, an overview of sources relating to the application of these standards and STEM/German/Foreign Language content in the classroom is reviewed. These refer to the teaching methods and pedagogies referenced and suggested throughout the documents reporting about current STEM education programs and foreign language programs. STEM education programs make strong references to inquiry-, problem-, and design-based learning and/or instruction that foster the integration of mathematics and science concepts in technology and engineering education. The teaching methods and literature relating to foreign language education

\footnotetext{
${ }^{1}$ It should be mentioned that the grade and content standards are constantly changing to fit the needs of education and society. This paper refers to the standards in each content area at the time of its creation and as referenced in the work cited section of this paper.
} 
suggest the use of content-based instruction and task-based instruction in classrooms. These methods combine CLT and language acquisition with the use of authentic materials relating to the STEM content areas and can promote interest in the areas of content by extending the use and knowledge of the concepts to other fields of study.

The body of literature relating to STEM education is scattered, but this thesis organizes the literature and combined ideas consistent throughout various reports, initiatives, legislations, books, articles, and presentations. The literature provides information about the nature of STEM and foreign language education, integration of academic subjects in STEM education, the benefits and need for STEM and foreign language education, and the pedagogy of integrating STEM and foreign language education. 


\section{Part 3: Examples of Instruction, Curricula and Programs}

The first chapter outlined the societal values and the need for educational reforms that can to produce students with valuable $21^{\text {st }}$ century skills. It also applied those concepts to two key subject areas, STEM and foreign language education. STEM education is defined as an interdisciplinary study between the "major food groups" (Angier, par. 3) of science and math education mixed with the hands-on learning of technology, engineering, and, possibly, other academic subjects. The current innovative programs and curricula in STEM education and L2 German education are working separately to better the quality of education in the US and cater more to the current knowledge of how people learn while providing an example of how to motivate, encourage, and involve learners. This chapter examines current STEM, STEM + languages and STEM + German curricula in the US and current efforts to improve and integrate the subjects now that they have been defined as socially valuable even if the general public is not always aware of that value.

There are few concrete guidelines or examples of an ideal STEM education curriculum; however there are numerous efforts, reforms and programs that promote what is defined as STEM education curriculum. Some STEM education curricula are modified for all learners and attend to the study of science and mathematics in relation to engineering and technology accessible to all, not just what are considered to be gifted learners (Peters-Burton 64-65); however, there are schools with a STEM education focus that have selective admission policies (National Research Council "Monitoring Progress" 13) and may or may not adopt newer pedagogical approaches. 
To understand the general components of all STEM education programs and the main components of STEM content area curriculum this paper turns to an article that mapped "scholarly communication in the field of STEM education" (Assefa and Rorissa 2514). The article clarifies all of the major components of each STEM field and how STEM education is widely defined. All existing articles found on the Web of Science and ERIC scholarly databases were searched by its authors to find knowledge areas related to STEM education through using a Co-word Analysis that associates words that co-occur (Assefa \& Rorissa 2515). The research analyzed each individual component of the STEM acronym (science education, technology education, engineering education, mathematics education). The following information was concluded about the separate fields in STEM education; Science education is a broad term that "involved teaching science to students at elementary, precollege, college and university levels;" teacher training; research activities; and the specific scientific content knowledge like "biology, chemistry, physics, technology education, environmental education, and mathematics education" (Assefa \& Rorissa 2520-2521). Technology education found the word co-occurrences of "industrial arts, design, electronic, internet, information technology, vocational education, energy, manufacture, and transportation," in addition to the less frequently occurring terms of "literacy, mathematics education, and standards" (Assefa \& Rorissa 2521-2522). The analysis of engineering education involved the terms "civil engineering, chemical engineering, electrical engineering, software, electronic, and technical education," and even broader terms that relate to "core knowledge areas," and "continuing and professional education" (Assefa \& Rorissa 2522). The range of co-occurring words 
relating to the field of mathematics education related more specifically to the subfields in mathematics. For example, common core knowledge areas of mathematics education are “algebra, geometry, calculus, number concepts, computer and computation, problem solving, mathematical concepts and mathematical skills" (Assefa \& Rorissa 2523). This study sought to explore the "underlying structure of STEM and STEM education" (Assefa \& Rorissa 2513), which will help explain the structures of currently existing STEM curricula, what the individual content fields cover, and what content knowledge is expected for integration. The major and common components of the fields helps create a starting point for integrating the major and common components of the STEM fields in foreign language classes. This information is important for understanding the components of STEM Education programs and then to reproduce these components in a well-rounded STEM + German/Foreign Language program.

The study also explored each individual field in the framework of curriculum development. By identifying the individual fields and their content, I could incorporate more of what was common among the fields in the learning modules and would help understand what components of STEM education could be used in a STEM + Foreign language curriculum. The result of this additional study and framework showed "the need for a statewide and/or national map, guide, and/or framework for program development and curriculum evaluation" (Assefa \& Rorissa 2524). The need for improvement, consistency, concrete definition, guidelines, and a framework relating to STEM education is not only an issue in curriculum development; it is also, as discussed in the previous 
chapter, an issue for the general public and stakeholder understanding of the need for improved education for science and mathematics content knowledge.

Although there is a general lack of consistency, lack of guidelines, and lack of definition, there are currently a number of STEM education programs and STEM education teacher-training programs that seek to use the concepts of STEM education and the individual fields to create STEM education curricula in schools and therefore better education in the US.

In 2011 the National Academy of Engineering and National Research Council STEM Education published an overview and analysis of integrative STEM education programs that is different from the general search through literature about STEM education in literature databases. This report detailed a two-year study researching "approaches and conditions most likely to lead to positive outcomes of integrated STEM (science, technology, engineering, mathematics) education at the K-12 level in the United States" (National Academy of Engineering and National Research Council vii). This report was based on existing programs, curricula, and their approaches to integrated STEM education. From the research done, the report developed a framework for programs to follow according to the practices of current programs. The studied programs were those that attempted to highlight connections "within, between and among STEM subjects" (National Academy of Engineering and National Research Council 19) as opposed to the historically separate and individual STEM subjects. The report found that integrative STEM education connects anywhere between two STEM subjects or concepts to three or more areas of STEM or the subjects falling under the "umbrella term" (Assefa 
\& Rorissa 2513), meaning the sub fields of science education, technology education, engineering education and/or mathematics education. Now that the programs are documented, the societal need for educational reforms has been created, and a potential solution through integrative and connected learning has been put into action, the framework the National Academy of Engineering and National Research Council created from their research has set the goal for further research in the effectiveness of integrative STEM education

The framework created by the National Academy of Engineering and National Research Council suggests goals, outcomes, implementation, and the nature and scope of integrative STEM education for current and future programs to support research in STEM education. The report focuses on Integrative STEM education: this approach to STEM education is defined as having experiences that involve some degree of connected learning. This connected learning can take place in a single class or course, several classes, throughout a curriculum, in an integrated STEM specific school, or through extracurricular learning opportunities. This variety in integrative STEM education makes sense for small changes to a system of education that has relied on schools and curriculum focused on "learning in discrete subject areas" since the late $19^{\text {th }}$ century (National Academy of Engineering and National Research Council 16) in a nation with a “decentralized educational system" (National Research Council "Monitoring Progress" 8). Since current knowledge in integrative STEM education is somewhat scarce and unclear, without clear instructions, methods, structure, and goals, this study created a 
framework for integrative STEM education, which will help with current and future research in STEM education.

The framework created by the National Academy of Engineering and National Research Council states that the goals of integrative STEM education are for students to gain literacy in the STEM subjects, be competent in $21^{\text {st }}$ century skills, prepare for the STEM workforce, increase interest and engagement, and help make connections among STEM disciplines.

The outcomes align somewhat with the goals and aim for student learning and achievement, development of $21^{\text {st }}$ century competencies, STEM course interest and enrollment, higher graduation rates, STEM-related employment, STEM identity development, and ability to make connections among STEM disciplines. The $21^{\text {st }}$ century skills and competencies refer to technological literacy through familiarity with some fundamental STEM concepts, understanding the roles of individual STEM subjects and ability to apply this knowledge to daily life, including new reports, and the "troubleshooting of common technologies" (National Academy of Engineering and National Research Council 34). STEM identity refers to the personal relevance of STEM subjects and careers that may be shown in the success and duration of STEM course pursuit in high school and higher education (National Academy of Engineering and National Research Council 69). These two goals set a framework for integrative STEM education and provide a purpose and overview of what integrative STEM education hopes to accomplish for students. 
In addition to the goals and outcomes for students through integrative STEM education, the National Academy of Engineering and National Research Council set goals and outcomes for educators. The goals for educators are to "increase STEM content knowledge" in themselves and "increase pedagogical content knowledge" (39). The goals relate to what the outcomes need to be. These outcomes are changes in practice and increased content and pedagogical knowledge. For these goals and outcomes to become a reality, the report suggests additional resources for professional development to help with new pedagogical content knowledge and content knowledge of STEM fields outside of their specialty. For the goals and outcomes of integrative STEM education to become a reality, educators must also revise their concept of the STEM subject classroom.

The framework for STEM implementation requires development of good services including instructional design, teaching methods and approaches, educator supports that provide opportunities to "improve STEM content knowledge and pedagogical practices" (National Academy of Engineering and National Research Council 43), and adjustments to the learning environment. This framework for implementation is closely related to the educator goals and outcomes because educators will need to gain new pedagogical skills and STEM content knowledge to improve their instruction and programs. New instructional design and teaching methods are needed in order to change practices. The previous frameworks are intertwined to create a better educational experience for educators and students; however, the final framework for integrative STEM education reviews the nature and scope of integration, which clarifies how integration should occur among the STEM fields. 
The National Academy of Engineering and National Research Council creates a framework for the nature and scope of integration by exploring "types of STEM connections, the disciplinary emphasis, and the duration, size and complexity of the initiative" (32). The types of STEM connections in the programs researched by the study combined concepts and/or practices from more than one STEM discipline. Combining content concepts and practices can be tricky, as it is difficult to find activities that effectively cover content knowledge while providing real world application in another field. Two specific examples of combining concepts and practices are "applying properties of geometric shapes (mathematics) to engineering design" and combining "two practices, such as science inquiry (e.g., doing an experiment) and engineering design (in which data from a science experiment can be applied)" in a STEM focused classroom (National Academy of Engineering and National Research Council 42). In the integrated activity, one subject often dominates with the other concepts and practices from the other STEM subjects integrated in the activity to "support or deepen learning and understanding in the targeted subject" (National Academy of Engineering and National Research Council 42). The nature and scope of the integration refers to the parameters of the integration, specifically to the conditions and layout of the experience.

Clearly, such integration of topics, knowledge, and activities with STEM itself is difficult. Interpreting and combining that material with language learning, especially of nonnative languages, is even more challenging. However, the combination and transition from the traditionally separate classrooms to the integrated classrooms is manageable by using texts appropriate to the language level of the students, and by teaching the texts 
through methods and approaches that shelter the material and allow language learners comfortable access to the language and content. This will become clearer in the later chapters of this paper.

The final framework overviews the instructional design, educator supports and adjustments to the learning environment as "factors that must be considered in the implementation of integrated STEM education" (National Academy of Engineering and National Research Council 43). Instructional design refers to the approach and structure of the experience. The report reviewed a variety of approaches from traditional, structured, direct approaches to student-centered, experiential, open-ended approaches. "Educator supports" refers to the opportunities for educators to improve on their STEM content knowledge and pedagogical practices through pre- and in-service professional development (National Academy of Engineering and National Research Council 43). The need for professional development is necessary to "support subject-matter integration" (National Academy of Engineering and National Research Council 44) and successfully adjust the learning environment through "extended lesson planning, team teaching, and other ways of development" (National Academy of Engineering and National Research Council 44). These elements serve as an "illustrative, not comprehensive" (National Academy of Engineering and National Research Council 59) framework built from the implementation factors of current programs, which will help with decisions about continuing programs after more, continuous documentation.

The overall framework, including goals, outcomes, implementation, and the nature and scope of integrative STEM education, helps make sense of current programs 
through "identifying and characterizing existing approaches to integrated STEM education" (National Academy of Engineering and National Research Council 31). The second chapter of the report exemplifies "Integrated STEM in the Harrisonburg City Public School System, Harrisonburg, Virginia" (National Academy of Engineering and National Research Council 27) by providing information on the factors in the framework of that program. The goals of the program in Harrisonburg are STEM literacy by "targeting specific STEM skills in students and teachers" (National Academy of Engineering and National Research Council 48). The nature of the integration involves all four STEM subjects and "engages students in engineering design process as a way to study core content through a variety of challenges (e.g., studying simple machines to discover what makes an elevator work and the design of bird beaks for capturing different kinds of foods)" (National Academy of Engineering and National Research Council 48). The integration also addresses standards in the STEM fields. The program refers to the educator support for implementation through the "STEM strategies developed at VA Tech," "'proven units"” available for teachers, and other professional development and research opportunities (National Academy of Engineering and National Research Council 48). The instructional approaches use engineering design to combine STEM subject elements in a "series of design challenges" (National Academy of Engineering and National Research Council 48). The outcomes of these factors created "cross-subject competencies and identity change in students" and modified teacher practices. This program expresses elements of the previously explained framework and results in the desired outcome of integrative STEM education. 
As an example of the previously mentioned educator support that improves content and pedagogical knowledge, Virginia Tech offers a STEM education graduate program, which focuses on using Technology and Engineering to combine the disciplines. The program's method is something they call PD+I, which stands for Purposeful Design and Inquiry. This pedagogy attempts to create "authentic inquiry" through design and draws attention to the individual STEM concepts and themes by explicitly and purposefully teaching and mentioning content knowledge when applying it to the design challenge (Sanders 21). Mark Sanders of Virginia Tech applies this method to recent cognitive science about how people learn and helps students grasp an abstract understanding of science and math through constructing and contextualizing (21). The program is designed to "develop $21^{\text {st }}$ century K-16 Science, Technology, Engineering and Mathematics (S.T.E.M.) educators, leaders, scholars and researchers prepared to investigative, teach and disseminate new integrative approaches to STEM education" ("Integrative STEM Education"). The program offers a Graduate Certificate, Master of Arts in Education Degree, Education Specialist Degree, and a Doctor of Education or Philosophy Degree and the courses offered in the graduate program contain the following core courses: STEM Education Foundations, Pedagogy, Trends and Issues, Research, Seminar, Biotechnology Literacy by Design and Field Studies in STEM Education. This program has been offered since 2005 and serves as a resource for educators wishing to be trained in the field of integrative STEM education.

Virginia Tech offers a graduate program for potential integrative STEM educators; however, it is not always possible for current educators in the STEM fields to 
return to educational institutions for further academic studies in integrative STEM education. In New Orleans, however, another option for educator resources exists. The New Orleans Regional Science and Mathematic Resource Center serves all public schools in New Orleans in providing educator resources (Gonzalez 26). The resources are available to "support the professional development and training needs of science and mathematics teachers new to the concept" (Gonzalez 26). The Resource Center provides teachers with instructional materials and professional development tools for hands-on, "application-oriented," and real world lessons, so educators can become comfortable with "the STEM approach" (Gonzalez 26). The tools available are computers, software, activity kits that can be returned, refilled and reused, and the Resource Center itself functions as a "lending library" and "training ground for STEM-based activities" (Gonzalez 26). This Resource Center represents further expansion of the professional development of educators wishing to adapt the classroom to reflect the recent need for innovative teaching in the STEM field.

In addition to the programs studied for specific STEM subject integration, movements, research and programs have developed around German as a foreign language, general foreign language education, and art integration in STEM education. Involving the arts in STEM has created its own acronym, STEAM (Science, Technology, Engineering, Arts, and Mathematics). STEAM education adds the arts into the integrative curriculum, but is still based on STEM education, and the arts are defined as "fine, language \& liberal, motor and physical (including: education, history, philosophy, politics, psychology, sociology, theology \& more...)" (Yakman 1). The arts can be added 
for positive outcomes by for example "making mathematics less threatening while maintaining its rigor," combining the way scientists and artists think, through explicitly applying the STEM concepts to making art, and how the arts can "broaden and deepen process and meaning for STEM practitioners" (Wynn \& Harris 43). Similar to the professional development for integrative STEM education, STEAM education has its own set of professional development opportunities involving "workshops, conferences, and other resources to assist teachers in planning STEAM approaches to classroom instruction" (Wynn \& Harris 45). The integrative nature of STEM education has not stopped at the STEM subjects, rather expanded due to the positive outcomes of connected learning.

Outside of L2 German specific STEM initiatives there are a number of teachersupports and programs surrounding the integration of STEM and second languages. For example, the Maryland State Department of Education developed a series of modules, available on their website, that combine STEM + Foreign languages in K-5 programs. The modules are designed for Arabic, Chinese and Spanish classrooms and provide teachers with detailed lesson plans including targeted standards, performance assessment, informative resources and worksheets to support the new classroom experience. The project that supported this initiative is titled the World Language Pipeline Program, funded by the Federal Race to the Top program ("World Languages Elementary STEM Curriculum Modules"), and supports 19 schools in Maryland providing second language courses (U. S. Department of Education, par. 2). The initiative required collaborative thinking between STEM educators and foreign language teachers to combine STEM 
subjects in foreign language instruction. This is not only an example of STEM + Foreign languages implemented in elementary curriculum in Maryland State Public schools, but also a resource for future educators wishing to implement STEM competencies in the foreign language classroom through exemplary modules.

The STEAM initiatives can include languages as a subject to be involved in the integrative teaching innovation. The AATG funded research in 2013 that supports STEM + L2 German in hopes to combine the two fields to improve enrollment in German programs and to assist teachers with professional development resources. A description of the grant outline is as follows:

“The AATG has grant monies from the German government's Netzwerk Deutsch program to fund five articulation projects in 2013. Eligible applicants are coalitions of middle school, high school and post-secondary teams or coalitions of high school and post-secondary teams. Project proposals must focus on developing and strengthening the connection between German and science, technology, engineering and math (STEM) subjects and providing the professional development necessary for German teachers to create and deliver STEM-based units of study." (Amer. Assn. of Teachers of German)

The research project titled "STEM.de. - STEM.US: Resources for Developing RealWorld Competencies in German + STEM," which is both a major source ad major focus of this paper and funded by the previously quoted AATG grant, provides L2 German teachers with resources for integrating STEM subjects in the L2 German classroom. The website provides resources for existing integrative STEM lesson plans, online databases 
for integrative STEM lesson plans, linguistic resources, pedagogical resources, information about standards, and assessment information. In addition to the AATG grant for "STEM.de. - STEM.US: Resources for Developing Real-World Competencies in German + STEM," the AATG funded an additional grant titled "AATG STEM Articulation Grant" (Amer. Assn. of Teachers of German, North Carolina Chapter) which aimed at producing six STEM + German units and the units are also available online. These projects are intended to support current L2 German curriculum with the integration of STEM subjects for increased $21^{\text {st }}$ century skills in addition to the competencies, literacy and proficiency that Language programs and STEM education programs support. Although STEM education instruction, curricula and programs are still in the development stages and are scattered throughout the nation, research by the National Academies, programs supporting the implementation of STEM education, and numerous funding agencies show the value and need for a reform in science education. Schools and Universities across the nation are developing teacher training and support programs that provide professional development for pre- and in-service teachers. The professional development reflects the current need and education standards, which reflect STEM education principles. As a result of the integrative nature of STEM education, other nonscience, technology, engineering and mathematics programs are adapting this principle and integrating STEM subject into art classrooms and foreign language classrooms. Although much research must be done in order to create a concrete program, curriculum, or method for integrative STEM education, current initiatives serve as an example for the basic concept of STEM education. 


\section{Part 4: Standards and Integration}

Outcomes, goals and structures of programs, curricula, activities, and the instruction of various academic subjects have helped develop desired the educational standards in the United States. This chapter will focus on the structure and implementation of the standards relating to STEM education and foreign language education. These standards are "The Common Core State Standards" (CCSS), "The Next Generation Science Standards” (NGSS), "The Standards for Technological Literacy” (STL), "The National Standards for Foreign Language Education" (NSFLE), and "The ACTFL Proficiency Guidelines.” The Common Core state standards are divided into two sections: English language arts education and mathematics education in the US. The other standards are specific to their fields. There is not yet a report or document for engineering education; however, there are documents that touch on other subject integration for disciplinary understanding including engineering in "The Common Core State Standards for Mathematics" (CCSSM), which is the mathematics section of the CCSS, and NGSS (National Academy of Engineering and National Research Council 107). The CCSS/M, while not having been adopted by all the States (National Academy of Engineering and National Research Council 6), are shown to be a valuable tool in creating integrated STEM education and can serve as a guideline for the integration of grade-appropriate themes with proficiency appropriate activities in the L2 classroom as they outline not only the core subject standards, but how the standards apply to other subjects. 
The CCSS has two sets of standards. The first set is titled "The Common Core State Standards for English Language Arts \& Literacy in History/Social Studies, Science and Technical Subjects" (CCSS for ELA/Literacy) and the CCSSM. Both sections in the CCSS focus on education for the next generation of K-12 learners in their respective subjects (Nat'l. Governors Assn. Center for Best Practices \& Council of Chief State School Officers "ELA/Literacy" 3). The standards were created by "state leaders, including governors and state commissioners through their membership in the National Governors Association Center for Best Practices (NGA Center) and the Council of Chief State School Officers (CCSSO)" and some teacher involvement ("Development Process") to create an "essential, rigorous, clear and specific, coherent, and internationally benchmarked criteria for college-preparation and job readiness in the $21 \mathrm{st}$ century" ("Common Core State Standards Initiative Standards-Setting Criteria"). The current CCSS are built off of the previous standards that have "been around since the early 1990s" (Common Core State Standards Initiative) and are considered to be a "living work" (Nat'l. Governors Assn. Center for Best Practices \& Council of Chief State School Officers "ELA/Literacy" 3) to be revised as needed to apply to the needs of learners.

Both sections of the CCSS are structured around a specific set of criteria, which demand that the standards be "essential, rigorous, clear and specific, coherent, and internationally benchmarked” ("Common Core State Standards Initiative StandardsSetting Criteria"). The CCSS must be essential in preparing students for workforce training programs and "entry-level, credit-bearing, academic college courses" ("Common Core State Standards Initiative Standards-Setting Criteria”). The CCSS will demand 
high-level cognitive functions, such as "reasoning, justification, synthesis, analysis, and problem-solving” (“Common Core State Standards Initiative Standards-Setting Criteria”). The CCSS must be clear and specific, so the criteria are teachable, learnable and understood by the general public. The CCSS must be coherent through a "unified vision of big ideas and supporting concepts within a discipline" and they must "reflect a progression of learning that is meaningful and appropriate" ("Common Core State Standards Initiative Standards-Setting Criteria"). Finally, the CCSS must be internationally benchmarked in that the standards correlate with those of high-performing countries and support students in succeeding and competing in the global economy (“Common Core State Standards Initiative Standards-Setting Criteria”). These criteria outline the structure and purpose of the CCSS and overlap with some principles of STEM Education in preparing students for competition in the 21 st century global economy, supporting concepts within a discipline, college preparation, and rigorous cognitive functions.

CCSS for ELA/Literacy covers requirements for English language arts and "literacy in history/social studies, science and technical subjects" (3). The standards in these fields are meant to support the specific discipline content standards, not replace them (Nat'1. Governors Assn. Center for Best Practices \& Council of Chief State School Officers "ELA/Literacy" 3). The overall structure of the CCSS for ELA/Literacy supports an "interdisciplinary approach to literacy" by assuming a shared responsibility among the subjects in fostering and developing students' reading, writing, speaking, listening and language skills “applicable to a range of subjects” (Nat'l. Governors Assn. Center for 
Best Practices \& Council of Chief State School Officers "ELA/Literacy" 4). The interdisciplinary approach relating to science and technical subjects is most apparent in the grade 6-12 standards in the section that outlines the "standards for literacy in History/Social Studies, Science and Technical Subjects" (Nat'l. Governors Assn. Center for Best Practices \& Council of Chief State School Officers "ELA/Literacy" 61-62), which relates to STEM Education and integration of science and technology in writing and reading capabilities. The standards in reading literacy in science and technical subjects relate to students' comprehension and analysis of texts, ability to follow written directions, draw conclusions and comparisons, and citation or written sources. The standards in writing literacy in science and technological subjects relate to the ability to formulate arguments, formulate informative and explanatory texts, organize information through coherent writing, edit and revise texts with and without the help of peers and mentors, create research projects containing material gathered from a variety of sources, answer research questions, and develop skills in a variety of writing situations relating to time, content, audience and goals. These standards in reading and writing literacy in science and technical subjects are supplementary to the content standards of NGSS and STL.

The CCSSM outlines content standards for mathematics and addresses the troubled mathematics curricula in the United States. The CCSSM states that mathematics curricula must become more focused and coherent to compete with those of highperforming countries. To assist with this goal, the standards must provide "clarity and specificity" (Nat'l. Governors Assn. Center for Best Practices \& Council of Chief State 
School Officers "Mathematics" 3) to mathematics education standards in grades K-12. Whereas the CCSSM does not "dictate curriculum, pedagogy, or delivery of content" it outlines what "students should understand and be able to do" in pre-college education (Nat'1. Governors Assn. Center for Best Practices \& Council of Chief State School Officers "Mathematics" 5).

Like the CCSS for ELA/Literacy, the CCSSM outlines expected student achievement and capabilities at each grade level between grades K-12. The topics chosen for each grade level were judged according to "state and international comparisons and the collective experience and collective professional judgment of educators, researchers and mathematicians" (Nat'l. Governors Assn. Center for Best Practices \& Council of Chief State School Officers "Mathematics" 5). They seek to develop and foster the following mathematical practices: make sense of problems and persevere in solving them; reason abstractly and quantitatively; construct viable arguments and critique the reasoning of others, model with mathematics; use appropriate tools strategically, attention and precision, look for and make use of structure; and look for and express regularity in repeated reasoning. In addition to the general mathematical practices that educators have striven to develop, each grade is provided with specific information about expected learning outcomes. For example, in the Grade K overview the mathematical practices are developed through the following: counting and cardinality, operations and algebraic thinking, numbers and operations in base ten, measurement and data, and geometry. Each section describes in detail specific student competencies like "count to 100 by ones and tens" (Nat'1. Governors Assn. Center for Best Practices \& Council of Chief State School 
Officers "Mathematics" 10) for clarity and specificity. Similar to the CCSS for ELA/Literacy, the standards change among specific fields in the higher grades. The standards for high school mathematics are divided into the fields of number and quantity, algebra, functions, modeling, geometry, and statistics and probability because high school mathematics involve integration among the subfields of mathematics. The CCSSM are not designed to formulate a mathematics curriculum; however, they can be used to guide a curriculum given that they outline student achievement, capabilities and knowledge in each K-12 grade.

As mentioned in "STEM Integration in K-12 Education: Status, Prospects, and an Agenda for Research" the CCSSM involve some STEM subject integration. Mathematics is required to be used in "applied contexts" (107). For example, in high school level geometry, the CCSSM suggest the following examples of applied mathematics in relation to technology and engineering:

"An understanding of the attributes and relationships of geometric objects can be applied in diverse contexts - interpreting a schematic drawing, estimating the amount of wood needed to frame a sloping roof, rendering computer graphics, or designing a sewing pattern for the most efficient use of material." (state and international comparisons and the collective experience and collective professional judgment of educators, researchers and mathematicians 74) The document also describes the application of algebra in geometry and "vice versa" suggesting further interdisciplinary activities and involvement. Further using math in real-world situations and other-subject integration, the CCSSM outlines standards for 
mathematical modeling. The CCSSM defines modeling as "the process of choosing and using appropriate mathematics and statistics to analyze empirical situations, to understand them better, and to improve decisions" (72). Not only in modeling are mathematical concepts related to real-life situations; the CCSSM suggests the use of technology to support working with models, further integrating the STEM subjects. For other non-STEM subject integration with mathematics, the CCSSM turns to "quantities and their relationships in physical, economic, public policy, social and everyday situations" and how mathematics can be integrated into these everyday situations (6). One example provided by the CCSSM of mathematical modeling is "relating population statistics to individual predictions" (72), which relates not only to mathematics in the real world, but demography and sociology. Modeling provides endless opportunities in integrating mathematics with other fields of studies and standards and will help in integrating the NSFLE, NGSS, and STL with CCSSM.

The NGSS covers the knowledge and skills students should gain in the sciences for college readiness and states the need for a solid K-12 education for all functioning adults ("Next Generation Science Standards Exec. Summary"). The standards outlined in the NGSS are based on the "Framework for k-12 Science Education," was created by the National Research Council and published in 2013 ("Next Generation Science Standards Exec. Summary"). The NGSS outlines the knowledge students should acquire at the elementary through high school levels and is intended to provide standards and goals, not an overall science curriculum ("Next Generation Science Standards Exec. Summary”), which makes it identical in purpose to the CCSS. The standards begin at the elementary 
level, and mention the need for conceptual knowledge of technology, engineering and applications of science (National Research Council "Science Standards" 3). This shows the early necessity of engineering and the inclusion of technology in science education. The understanding of science concepts in the NGSS is based on cumulative knowledge in the different subfields of science. The NGSS begin with elementary education as a basis for students to "develop ideas and skills" in physical sciences; life sciences; earth and space sciences; and engineering, technology and applications of science; so they can "explain more complex phenomena in the four disciplines as they progress to middle school and high school" ("Elementary”). The NGSS build off of each other at the different grade level, so that the knowledge is cumulative. The NGSS reviews student understanding in k-12 education by explaining what questions students can answer, concepts students should be familiar with, tasks students can accomplish, and how students apply their knowledge. Like the CCSS, the NGSS is created to meet the needs of 21 st century skills required for student's success.

The NGSS were developed according to the National Research Council's framework for proficiency in science, which contains three dimensions: practices, crosscutting concepts, and disciplinary core ideas ("Three Dimensions”). The Framework considers science "as both a body of knowledge and an evidence-based, model and theory building enterprise that continually extends, refines, and revises knowledge," and combines the three dimensions in the development of the standards to support this concept of science ("Three Dimensions"). First, "Practices" are the behaviors that engage a student or person in scientific inquiry and engineering design that combine 
both skill and knowledge. Both scientific inquiry and engineering design involve problem solving through investigation, either through questioning and research or through design, and relate to everyday problem solving. The dimension named "Crosscutting concepts" explores explicitly linking the scientific domains of "patterns, similarity, and diversity; Cause and effect; Scale, proportion and quantity; Systems and system models; Energy and matter; Structure and function; Stability and change" ("Three Dimensions"). "Crosscutting concepts" seeks to integrate knowledge from all science fields, in order to develop a "scientifically-based view of the world" in students ("Three Dimensions"). The third dimension of "disciplinary core ideas" focuses on the "most important aspects of science" in physical science, life science, earth and space science, engineering, technology and applications of science ("Three Dimensions"). Like the CCSS, the NGSS requires a great deal of integrated and interdisciplinary learning that applies directly to STEM education, as all of the standards include some sort of STEM subject in addition to another subject as a section of principle of their goal.

The next set of standards that relates to STEM education is "The Standards for Technological Literacy: Content for the Study of Technology." These standards were created to outline the "core of technological knowledge and skills" for "K-12 students to acquire" upon graduation of high school (International Technology Education Association v). The justification for the standards is to produce technologically literate high school graduates. Technological literacy is defined as "the ability to use, manage, assess and understand technology" (International Technology Education Association 9). The need for a technologically literate public is, so that they can engage in decisions, 
which could help shape the technological future of the United States. The STL is similar to the CCSS and the NGSS in that it is integrative in nature, is intended to be a guideline and not a concrete curriculum, is laid about by grade level, and sets standards for high school graduates.

The STL is divided into five categories of knowledge and/or skills and describes the goals in each category for k-12 classrooms. The categories are the nature of technology, technology and society, design, abilities for a technological world, and the designed world. The "nature of technology" category covers general technological core concepts, relationships among different technologies, and the relationships between technology and other areas of human achievements (International Technology Education Association 21). "Technology and society" explores the "cultural, social, economic and political effects of technology", in addition to technology's effect on the environment, how society develops and shapes technologies, and technology's influence on history (International Technology Education Association 210).

The third category "design" tackles the fundamental processes in the creation of technology. Technology design teaches valuable abilities such as teamwork and problem solving, and requires various troubleshooting, research, development, invention, innovation, and experimentation skills to complete a task (International Technology Education Association 210). Following "design," the STL creates the category of “abilities for a technological world" that outlines standards in students' ability to use and maintain technologies through mental tools such as problem-solving, visual imaging, critical thinking, and reasoning (International Technology Education Association 210). 
The final category in the STL is "the designed world," which deals with students" abilities to select various technologies in the world of human invention and intervention (International Technology Education Association 213). The technologies are broken down into the following fields: medical, agricultural and related biotechnologies, energy and power technologies, information and communication technologies, transportation technologies, manufacturing technologies, and construction technologies (International Technology Education Association 15). These categories will help prepare students for real-life decisions and situations, while integrating other STEM and academic subjects in their teachings.

The CCSS, NGSS and STL directly relate and mention integration of STEM subjects, not only in science, technology, engineering and mathematics classrooms, but also in language arts and the humanities classrooms. This is essential to the concept of STEM education and the necessity for deeper learning through subject integration and the interdisciplinary focus of classrooms. There is no official set of published engineering education standards for general use; however, the need for engineering topics, lessons and education is apparent, as it is mentioned throughout the three categories of standards explored in this thesis paper. These standards are connected through their text and even technology education, while not nationally adopted as a core subject (International Technology Education Association 2) still is mentioned in the CCSS for mathematics and language arts, and the NGSS as content necessary for high-school graduates.

Separate from these categories, however, is foreign language education and their standards. Understanding the National Standards for Foreign Language Education 
(NSFLE) from the "Standards for Foreign Language Learning in the 21st Century" and the ACTFL Proficiency Guidelines would be necessary for conceptualizing appropriate content, implementation, and guidelines for integrating other subjects and their standards into the second-language classroom and how sections and goals of the content standards align.

Before the creation of NSFLE and more of an ongoing guiding principle for foreign language education are the ACTFL Proficiently Guidelines. ACTFL, the U.S. Government Testing Agencies, and the Educational Testing Service collaborated to create a valuable set of criteria, which became the ACTFL Proficiency Guidelines (Liskin-Gasparro 483). These Guidelines outline "models of language proficiency" (Liskin-Gasparro 483) and were first published in 1982. The most recent publication of the ACTFL Proficiency Guidelines is a 2012 version and it outlines Reading, Writing, Listening, and Speaking

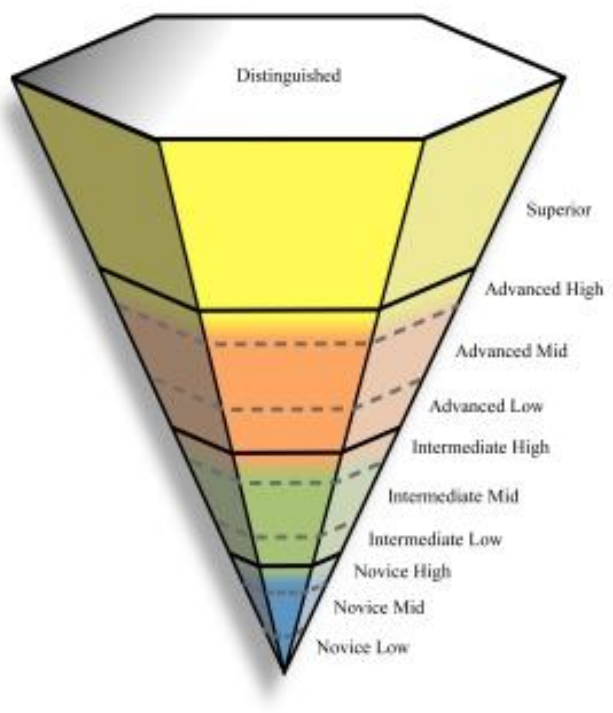

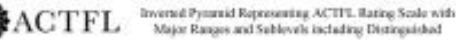

Figure 1: ACTFL Proficiency Guidlines Rating Scale; Guidelines Pyramid. Digital image. ACTFL Proficiency Guidelines 2012 | American Council on The Teaching of Foreign Languages. American Council on the Teaching of Foreign Languages, n.d. Web. 30 July 2014. <http://www.actfl.org/publications/guidelines -and-manuals/actfl-proficiency-guidelines2012>.

capabilities of language learners. The Proficiency Guidelines model levels of language proficiency from Novice, Intermediate, Advanced, and Distinguished language speakers, readers, listeners, and writers. Some of the models have subdivisions and are given the 
description of Low, Mid, and High level capabilities of their respective major groups. A diagram of these ranks and models can be seen in Figure 1 of this chapter; language teachers commonly refer to as the "mounted pyramid." This has Novice Low at the bottom of the cone as the lowest form of linguistic capabilities and Distinguished as the highest level of linguistic capabilities. The proficiency categories ranking from Novice Low to Distinguished model learners' linguistic capabilities in their ability to produce certain grammatical features, to recreate native-like pronunciation, to create texts with a certain level of discourse about certain topics, to be understood by native speakers, and examples of mistakes and limitations. These guidelines have changed the nature of foreign language education and have created much research about the field of foreign language education (Liskin-Gasparro 489).

These Proficiency Guidelines have become an "organizing principle for instruction," a term coined by Higgs and quoted in Liskin-Gesparro’s (484) article about the history of the ACTFL Guidelines, as they have changed the dynamics of foreign language instruction from teacher-oriented controlled classrooms to student-oriented and communicatively focused classrooms and activities (Liskin-Gasparro 484). In view of the Guidelines emphasis on communication it is not surprising that oral exams of students in classrooms before implementation of the ACTFL Proficiency Guidelines led to a mismatch of linguistic content being taught and the oral linguistic capabilities of students (Liskin-Gasparro 484). From this realization, educators- or at least some of them - began to increase student speaking of the target language in the classroom, while grammar instruction became a tool supplemental to the main focus on communication (Liskin- 
Gasparro 484), correspondingly the focus of the classroom became matching student performance to that of the proficiency models. The ACTFL Proficiency Guidelines are also not completely separate from the NSFLE, as the guidelines fall under the category of "communication" (Liskin-Gasparro 484). The "communication" standard of foreign language education focuses on students' written and oral interpersonal communications, interpretation and understanding when listening and reading, and ability to formally present information to peers. The ACTFL Proficiency Guidelines model performances in the foreign language that help support the goals of the $5 \mathrm{Cs}$ and help model curriculums to support students abilities to communicate at whatever given level of proficiency.

The development of the NSFLE started in 1993 and was a product of collaboration between the American Council on the Teaching of Foreign Languages (ACTFL), the American Association of Teachers of French (AATF), American Association of Teachers of German (AATG), and the American Association of Teachers of Spanish and Portuguese (AATSP). The initial formulation of these standards began around the same time as the other core content areas and, like the other content areas, underwent numerous revisions. The NSFLE also has five goal areas in which the standards are formulated and they are called "the Five C's of Foreign Language Education" (National Standards in Foreign Language Education Project, 1996). The first is "communication" (National Standards in Foreign Language Education Project, 1996), which is the guiding principle of foreign language education because the core reason for using and speaking a language is to communicate ideas face-to-face, in writing and in reading. The second goal is "cultures" (National Standards in Foreign Language 
Education Project, 1996) and strives for students to gain knowledge and understanding of the target culture. The third goal is "connections" (National Standards in Foreign Language Education Project, 1996) between other disciplines and using the knowledge and viewpoints gained in the second-language classroom to support the learning in other classrooms. The fourth goal is "comparisons" between the target language and the nativelanguage and from that comparison learn about the nature of language and how languages function (National Standards in Foreign Language Education Project, 1996). Another aspect of "comparisons" is to compare the culture of the target language to the nativeculture, in order to recognize patterns of similarity and difference, and the concept of cultural systems (National Standards in Foreign Language Education Project, 1996). The final goal is "communities," which seeks to tie the target language to extracurricular uses and lifelong learning. Throughout accomplishing these goals, students will gain proficiency in the target language's grammar, vocabulary and culture for appropriate use of the language. The NSFLE does not provide grade-level explicit expectations for what students should know because foreign languages are not uniformly and consistently in k12 schools in the US. These standards are not intended to be a curriculum for foreign language programs; they act as a guide in creating a meaningful educational experience.

The primary goal in this set of standards that will help with the integration of STEM and foreign languages is "connections." Naturally students will use their developed "communication" and "comparison" skills to acquire connections and make them explicit; however, this goal seeks to integrate the concepts of other fields with foreign language. Foreign languages can be used to "expand and deepen students' 
understanding of, and exposure to, other areas of knowledge" and can assist with continued learning of the foreign language (National Standards in Foreign Language Education Project, 1996). Although the NSFLE does not provide explicit goals in supporting the sub fields of STEM education, it mentions as one of its goals the necessity of integration for deeper, meaningful learning.

The standards throughout k-12 education in the United State have interdisciplinary studies and subject integration as a consistent and unifying goal. The concept of integrating STEM education and foreign language education can be made possible and would be supported by the goals outlined in the various standards documents. In the CCSS, mathematics uses modeling to integrate other subject material and language arts wishes to combine other subjects in supporting students reading, writing, speaking, listening and language skills (language meaning English-language skills). The NGSS supports the integration of different STEM subjects to support connected learning. The NSFLE seeks to combine foreign languages with all other disciplines in hopes to deepen the learning experience. STEM education seeks to combine one or more STEM fields with themselves or with other academic subjects and the goals of the standards support overall integration; therefore supporting the integrative nature of STEM education. All support the integration of subjects to promote deeper learning and a practical application to all subjects and through applying standards to learning goals and lessons, integration can be possible to support desired outcomes of student learning. 
Part 5: Teaching Methods for Combining STEM Education and Foreign Languages

The need for STEM education to act to improve current science and mathematics education is apparent in several academic reforms, programs and research. At the same time, Foreign language education is necessary for our nation to continue to thrive as one of the world's global leaders. Bringing these two requisites together requires attention to the standards of the relevant subject areas and also to current examples of STEM education and foreign language education programs, instruction and methods, such as those discussed in the previous chapters. At the heart of combining STEM and language learning through required, suggested, and exemplified learning goals and expectations are the teaching pedagogies and theories that support the various teaching approaches. This thesis focuses on content-based instruction, task-based instruction, problem-based learning, and inquiry-based instruction for the integration of STEM in the foreign language classroom and the pedagogies they support. The following description and argumentation supporting these approaches will be explored in this section about creating lesson plans that integrate STEM and foreign language education. These pedagogies are used in current STEM integrated foreign language programs and in current STEM education programs.

The main method of teaching and learning a foreign language with the aspiration of STEM integration discussed in this paper is the instructional approach of Content Based instruction (CBI), which supports Krashen's theory of second language acquisition and his comprehensive input hypothesis (Grabe \& Stoller). It is important to use a 
method that follows Krashen's theory because the theory more accurately follows how people learn and acquire language and Krashen's idea is persuasive in foreign language pedagogy. First, one must understand the difference between language learning and language acquisition in regard to second language learning. Language learning relates to the conscious learning of a language, when by contrast language acquisition is the subconscious process of learning a language for effective communicative use (Krashen 12). Language learning can be related to how we study languages in a traditional academic setting; where students learn something about languages. Krashen (2) describes learning as language learned through error correction and explicit attention to rules; however, the sequence of material covered in a syllabus or taught through error correction is not necessarily how the second language is acquired and can be used by the second-language learner. The acquisition of language compares somewhat to how people learn their first language as children, which requires interaction that focuses on meaning instead of form (Krashen 1). Negotiating meaning is what the CBI will focus on when using content to acquire language.

$\mathrm{CBI}$ relates closely to language acquisition in the activities and methods it uses. $\mathrm{CBI}$ is the learning of language through other content. Language itself has no content and traditional language courses often use the language itself or the target culture as the content for learning the target language (Stryker 6). Content courses are academic courses that teach information (Heo 26), and the concept behind CBI is, that the target language will be used to teach and comprehend various contents. For example, biology is a content course and the material taught in a biology course or material relating to the 
content in a biology course can be taught in the target language with special attention to materials and activities used in the class, and of course with attention also to appropriate pedagogy. CBI integrates content learning and language learning and promotes language use for real-world communication by focusing on the subject matter rather than the forms and functions of a language (Stryker 6). The syllabus or curriculum in a CBI course would focus on the subject matter rather than the knowledge about the language itself, which is how traditional language courses structure their curriculum. The language is learned through its use relating to the content and the content - biology or another content area - is learned along with the language. The content, however, would be learned at a slower pace in the foreign language classroom than in a course about that subject conducted in the native language.

CBI does not neglect grammar and linguistic structures. CBI focuses on learning structures and vocabulary within the context of the text being used. For example, a technology class could read instructions to put together a computer, or a science class could read instructions for setting up a lab or experiment. For example an instructional booklet might contain verbs such as "to connect" or "to plug in." The imperative, or command form of the verb would look something like; "Connect the cord to the base." Both of these instructional information texts will or should contain some of the imperative form of verbs. Highlighting these structures in the text and then reproducing them will help the students acquire certain structures and vocabulary through maximum exposure of the language. The text may be something modified to the students level of 
language proficiency; however, the structures and vocabulary should be used authentically within the texts and observed in context.

CBI supports language acquisition and Krashen's comprehensible input hypothesis. Krashen's comprehensible input hypothesis argues that language is acquired through constant exposure to comprehensible second-language input (Grabe \& Stoller) and CBI supports this hypothesis by teaching content in the foreign language as a method of constant input. CBI does not provide explicit teaching of the language; instead language acquisition occurs in the $\mathrm{CBI}$ classroom through the content instruction in the foreign-language (He 26). For this second language acquisition to be successful the materials in the CBI classroom must be linguistically authentic, appropriate in level, focused on the subject matter of the content area, cater to a variety of learning styles, and use the language as a tool to communicate (Stryker 6-11).

Linguistically authentic material in the foreign language classroom means using what is produced in the content area for native speakers of the target language (Stryker 8). For example, if a CBI course for biology in German were to be taught, the instructor could find authentic resources from online articles from German language news sources in their Wissenschaft (science) sections or the instructor could use resources, such as lesson plans, handouts, and materials, intended for the native German speaker. The instructor could also use textbook materials from the target language's classrooms and curriculum for use in their foreign language classroom. The texts should be appropriate to the proficiency level of the classroom. The texts may be relating to the STEM content 
area or actual content literature, which can be anything from children's books about the subject about the content to textbooks and articles about the subject.

It is necessary to use authentic materials because artificially created language leads to no proficiency gains (Stryker 8). When artificial language materials are used in the second language classroom, students can become frustrated because the material is not a real representation of how the language is used to communicate (Stryker 9). Authentic materials provide the opposite; they give students an example of how the language is used for communication, they have "natural redundancy" or repetition that allows for comprehension (Stryker 9) and they challenge students to attain a higher level of proficiency (Salazar 5).

Krashen also identified in his input hypothesis something called the " $i+1$," which relates to this type of input. "I+1" is defined as the ability of foreign language learners to comprehend a level of language above (1) their own proficiency level (i) (Salazar 2). "I+1" input is necessary for the development of higher proficiency levels in a second language. Outside of linguistic achievement gained from using authentic texts in the classroom, students will develop increased levels of self-confidence which lead to higher motivation, achievement, and linguistic coping mechanisms: handling unknown vocabulary, and encountered grammar, and unpredicted situations where and when the language is spoken (Stryker 9). Linguistically authentic texts are a necessity in the CBI classroom and for proficiency gains.

Authentic texts need not be scholarly articles about the content, they can be articles or texts produced by a native speaker about the content area resources, and can be 
edited to cater to different levels of student proficiency. For example, a good online resource for students learning German as a foreign language is Deutsch-perfekt.com. On this website articles about various topics can be found for German-language learners. The categories for articles are divided into politics, business, culture, sport and a section on general news. The articles provided on this website are assigned levels of difficulty and provided with vocabulary assistance and it is an authentic text, as it is written naturally by native-speakers. A CBI course could use one of these articles in a classroom to support discussion of the content. One article titled "ein heißer Supercomputer," or a Hot Supercomputer, can be used in a technology course. The article discusses Supermuc, a supercomputer, which produces a lot of heat, and the heat is used to heat houses by heating water transferred into houses. This article is listed described on the website as easy, and could be used in a technology content course taught in German. The student could be prepared to read the article with activities that discuss energy conservation, how heating works, how computers are cooled, and other topics relating to this kind of technology. The students could practice new vocabulary before reading the article, or instructors could "shelter" the text. In this example, the language is being used as a tool to communicate content. The lesson would focus on computer technology, energy conservation, and innovative ideas explained and constructed in German as the foreign language being studied. Videos, audios, and activities that relate to different content that can also be found not only online, but also through print (magazines, textbooks, newsletters, etc. in the foreign language) and teacher resources. 
Authentic texts can be intimidating for students and language instructors; however, this can be avoided with proper understanding of how to incorporate these texts in the foreign language classroom, or how to use and explore the authentic texts as opposed to concerns about what kinds of texts they are and how complicated they may be (Stryker 8). One method of exploring a text is called "sheltered instruction," where the instructor guides the students in understanding a text and makes the text, which may be above the students' level of proficiency, accessible to them (Stryker 16). Good instructor techniques for sheltered instruction are highlighted in Content Based Instruction in Foreign Language Education (Stryker) and are:

Varying the format of classroom instruction, using group work and team-building techniques, organizing jigsaw reading arrangements, defining background knowledge and language skills required for student success, helping students develop coping strategies, using process approaches to writing, using appropriate error correction techniques, and developing and maintaining high levels of student self-esteem. (Stryker 293)

The teacher must make a comfortable learning environment in which sheltered instruction exists to ensure its success. This can be done with proper implementation of the text through sheltered instruction.

Another aspect of CBI that assists with language instruction is the flexibility it gives for teachers to adjust their instruction to varying learning styles and student interests. Since the content of language instruction would not primarily focus on the form and function of language outside of communicative purposes, the content of a CBI course 
is open to foster student interests and integration of real-world applications. For example, a CBI course can integrate other subjects learned in the school curriculum in order to connect the foreign language with other academic subjects taught in the school or university's curriculum. Immersion language programs do this as a matter of course. A CBI course could also link the foreign language to the professional goals of students by using language and themes appropriate to the profession. The CBI classroom can also satisfy the personal academic needs of students (Stryker 90). If teachers closely monitor students' linguistic development they can focus more on language not acquired by the students (Stryker 11). Teachers can additionally vary in content presentation to cater to different learning styles and learner profiles; for example, presentations can be done through lectures, reading, discussion, and/or varying experiential approaches such as role play, workshops, simulations, field trips, demonstrations, and/or native speaker interaction (Stryker 10) in order to support students with various learning profiles. If students have a voice in the activities relating to the CBI course help them understand how they learn and how they can continue learning outside of the classroom and without the teacher as an assistant (Stryker 72). Teachers can help students develop strategies and understand their learning preferences through student self-assessment and varying classroom presentation.

Language in the CBI classroom must be used for meaning and communication; therefore, the focus must be on the communication of meaning from the content, not the functions and forms of the language. This can also be intimidating and new as it is different from many students' concept of language learning so it is necessary for teachers 
to create a non-threatening open-dialog classroom, as discussed in the previous two paragraphs. CBI courses and instruction use a "top-down" approach, which tackles meaning before "sentence level operation of vocabulary and syntax" (Stryker 6). The traditional approach to language instruction uses a "bottom-up" method, which focuses on words and syntax structures on the sentence level (Stryker 6). CBI links the language to the content for more meaningful use, rather than learning and manipulating linguistic forms, as was the focus of traditional foreign language classrooms.

There are variations in approaches to the CBI classroom and curricula that make the content and language easier to teach and acquire. The material can be represented first in the native language and then "recycled" in the foreign language (Stryker 11). The material can also be slightly edited to fit the classroom's proficiency goals and levels of comprehension (Stryker 8). Aside from the material, the classroom can be taught by adjunct instructors, meaning an instructor with foreign language education background would collaborate with the content instructor in teaching the class (Stryker 20). The classroom could also focus on themes to supplement the grammar, where the grammar is linked to and defined by the topics (Stryker 4); therefore, the focus of the class or curricula would be the content or topic and the grammar lesson would support the communication of the content. Referring to ta previous example, when the grammatical imperative is conjugated by reading and using a technical manual. All of these variations and adjustments to the $\mathrm{CBI}$ approach support the integration of various content in the foreign language classroom. 
$\mathrm{CBI}$ is the ideal approach to language instruction for the purposes of foreign language and STEM integration. Foreign language courses can use content from STEM education classrooms and curricula or content from the individual STEM subjects as a vehicle for the language to be learned. Since STEM education focuses on real-world use of the concepts and principles and foreign language education focuses on the communicative properties of language, CBI would be a pedagogical solution to the lack of program integration. $\mathrm{CBI}$ approach to language learning for the purpose of this thesis would focus on the content of STEM education - the integration of science, technology and engineering education in their respective subjects and across curricula - in the foreign language classroom.

In addition to the solution this approach brings to the integration of foreign language and STEM education, other methods support the integrative nature of the CBI classroom and the goals of STEM education. Task-based instruction (TBI) is one method to use in the CBI classroom. TBI uses tasks to organize a syllabus, lesson or curricula and, like CBI, focus on meaning, real-world application of the language, and uses rich and authentic materials (Brandl 8-9). A task is "a workplan that requires learners to process language pragmatically in order to achieve an outcome that can be evaluated in terms of whether the correct or appropriate propositional content has been conveyed" (Ellis “Task-Based Language Learning" 16). This means students must comprehend language in a given problem, question, activity, or situation and the outcome of the situation must communicate a response or desired outcome from the content used. Another aspect of the task is, that the outcome should "result in language use that bears 
resemblance, direct or indirect, to the way language is used in the real world" (Ellis “Task-Based Language Learning" 16); therefore, the task would ultimately be used for communicative purposes, however, it would also indirectly focus on appropriate use of the language relating to the task. The task would focus on the content being taught in the classroom and it would be completed in the target language through "achieving a goal or an objective, or arriving at an outcome or end product" (Brandl 9).

A general framework for task based instruction focuses on the first the pre-task activities, the during-task activities, and the post-task activities (Ellis, "Methodology" 80). The only obligatory activity for a lesson to be task-based it the during-task activity; however, the pre- and post-task activities may support acquisition and focus on form (Ellis, "Methodology" 81). The pre-task phase of a task-based lesson might focus on framing the task-based activity, establishing an outcome, and providing linguistic resources to reduce students' cognitive or linguistic demands (Ellis, "Methodology" 83). Methods of framing the activity might be through performing a similar task, observing a model form of the task, or explicit instruction on how the task will be performed (Ellis, "Methodology" 83). Background information and/or vocabulary may be presented to assist with the performance and ease the processing load of the students (Ellis, "Methodology" 85). For the during-task activities, instructors would need to establish time frames, materials, and discourse. The time frame would affect the language being produced and materials, or input data, would help with new vocabulary and concepts. Students on a time frame would produce more fluid language, whereas students without a time frame may produce more accurate language (Ellis, "Methodology" 85-86). The 
input data, for example texts, pictures, vocabulary, may assist with the task. For discourse, instructors would need to focus on the language produced by the students.

The task would require student-centered interactions in groups or partners and the instructor would need to guide and shape of student discourse (Ellis, "Methodology" 87). The instructor would need to guide students in using the language as a tool rather than something to be studied and for completing the task; the language must be used as a means to communicate meaning. The post-task activity would provide reflection on the main task. Post-task activities may involve a repeat of the main activity, attention to forms used in the main activity, and a reflection on how the task was performed (Ellis, "Methodology" 93). In the post-task stage, instructors can focus on forms not acquired by students (Ellis, "Methodology" 93), which relates directly to focusing on student needs in CBI. An instructor will need to play close attention to student linguistic development in order to focus on forms that students do not acquire and adjust the instruction to bring explicit or implicit attention to the forms.

Task-based instruction allows instructors to use the language for meaningful communication in the classroom while allowing for adjustments and student-centered approaches. The task can focus on content not related to the study of a language; for example, the task could focus on describing where different organisms live and how they move. Students would need to describe the mode of locomotion for various forms of life in their habitat and the instructor can provide vocabulary and information for students to complete the task. The lesson would focus on the third person singular forms of verbs, preposition and vocabulary relating to things in nature. From modeling communicative 
sentences like "the frog hops on land and swims in ponds" students can formulate their own sentences in the second language that describe the locomotion and habitat of the organism provided - or of still other organisms. Of course this can be done with images and vocabulary as input data to support the linguistic development of students.

This example lesson or activity could be a larger part of a content-based course on life sciences and/or biology taught in a foreign language and could even be used in classrooms with lower levels of linguistic proficiency. Another example could be a lesson based around an internet search explained and performed in the second language, or even adding and subtracting in a task relating to time or shopping. The tasks could also be an activity that focuses on the use of the language for STEM integration as a small part of a lesson or supplementary activity that connects the disciplines, but does not focus its curriculum around STEM content. These are tasks that support 21st century skills and STEM education because they are performed and communicated in a foreign language, relate to real-world situations, integrate more than one academic topic and lead students to authentic inquiry and problem solving situations.

In addition to the two methods of instruction for the foreign language classroom, two elements of STEM education can be incorporated into the classroom that supports 21 st century skills and education standards. These are approaches to problem-based learning (PBL) and inquiry-based instruction (IBI). PBL is STEM education's equivalent to language learning through TBI. PBL is "an instructional method that initiates students learning by creating a need to solve an authentic problem" (Hung, Jonassen, \& Liu 486) 
and requires the use of concepts from science, mathematics, technology, engineering and other academic subjects to solve real world problems.

To create a classroom that focuses on problem-based learning, the task would need to focus on students answering an authentic question or solving an authentic problem while using concepts from the content course, all relating to real world application of the concepts and content. PBL embeds learning in real life, real world situations, which supports longer retention of concepts and deeper learning (Hung, Jonassen, \& Liu 489). This is based on the constructivist idea of learning, which assumes that knowledge is "individually constructed and socially co-constructed from interactions with environment" and not transferred (Hung, Jonassen, \& Liu 488), as would be attempted in the traditional classroom. Constructivist assumptions about learning also state that there are multiple perspectives to phenomenon, forms of meaning and thinking are created through the culture, community and are dependent on the tools of that culture and community, and knowledge relies on context for relevancy (Hung, Jonassen, \& Liu 488); therefore, rooting the problem in a real-world context is necessary to approach learning from a constructivist perspective. PBL was formulated to support these assumptions (Hung, Jonassen, \& Liu 488) and can be combined with CBI and TBI to create a unique atmosphere for language learning and STEM education.

Like TBI, PBL has a general structure and can be used to create a lesson or series of lessons surrounding its structure. Students will formulate groups and are given a problem that they must explore with the knowledge they already have acquired relating to the problem. Problems should be "messy and complex," live everyday problems in real- 
life, and from this chaos and open ended problem, students will work together to use the knowledge they have to find a solution (Hung, Jonassen, \& Liu 491), similar to providing students with authentic texts and sheltered instruction in TBI. Students will make a rough outline of a solution to the problem and from this, hypothesize about next steps or potential outcomes of the solutions (Torp \& Sage 22). They can define the limitations of their knowledge on the subject, define what learning activities are required to successfully solve or tackle the problem, and assign tasks to individuals within the group (Hung, Jonassen, \& Liu 489). Students will then undergo self-directed study, in which the individuals will complete their assignments related to the problem, collect resources and prepare reports (Hung, Jonassen, \& Liu 489). After students collect new information and resources, they will revisit the problem and generate a new hypothesis that will tackle the problem with the information learned (Hung, Jonassen, \& Liu 489). Finally students will summarize and discuss the problem, solution and integration to content concepts (Torp \& Sage 21). This process allows students to own the problem they are tackling and use the knowledge they have gained in solving a problem with many potential solutions. Students, although guided by the instructor, are self-regulating and autonomous on the group and individual level, which promoted responsibility, autonomous learning, and motivation. Overall the process encourages students to integrate the knowledge they have to solve a problem and doing so it can serve to be an example for students solving the everyday problems they encounter.

This process can be confusing and defining a messy, ill-structured problem can be difficult. An example from Problems as Possibilities: Problem-based Learning for K-12 
Education exemplifies an authentic problem and the steps students must take to find a solution. The problem presented to elementary school students was, that a former principal of the school was having trouble maintaining his flower garden; (Torp \& Sage 6). The students had to first compile ideas about how to maintain a garden, then they used resources and research methods to tackle the problem; and finally they compiled a new guide for maintaining a garden using recycled knowledge and newly gained knowledge from their research (Torp \& Sage 6-7). The research methods for garden maintenance was research conducted from online resources, hard-copy resources, contacting local experts, and experimenting with plant growth under different conditions (Torp \& Sage 67). From this example and the general framework for PBL lessons can be built to integrate the nature of learning from PBL and the method of instruction in CBI and TBI.

To integrate foreign language learning and PBL, one could create a lesson similar to the following: An exchange student needs to take public transportation every day, including the weekend, into town from their home in the target-culture's country and she has no experience with public transportation in her home or exchange country. Students must create a guide for the exchange student in the target-language by collecting realia from the teacher (timetables, pamphlets, etc.) or by visiting online resource, finding vocabulary relating to public transportation, and potentially contacting the foreignlanguage speakers as an additional resource for information on the public transportation system in the target-city/country. This lesson could be structured around the task of creating a resource for an exchange student in the target-culture and the pre-task phase would involve PBL's pre-test phase in developing a solution, or in this case the materials, 
with the knowledge the student already has about the target-culture and target language. This lesson tackles the issues of technology and engineering by exploring technological design and man's interaction with the tools created. The during-task activity would involve the research and composition of an actual pamphlet and research that allows students to gain new linguistic and cultural knowledge relating to the theme of transportation. The content of the course could be technology and the technology being studied would be transportation technologies. Additionally relating to CBI, the texts and resources used would be authentic materials from the target-culture in the target language.

Finally, another approach to instruction and learning relating to the Integration of STEM education and foreign language education is that of Inquiry-Based instruction, which is based off of the way people "formulate questions, explore problems, observe, and apply information in seeking a better understanding of the world" (Warners \& Myers 1). This closely follows the scientific method, which begins with a question, followed by research and hypothesis, testing the hypothesis through experimentation, analysis of data, and finally a conclusion from the process. Like the scientific method IBI begins with a question and the details of the question are researched. From the research, a hypothesis is formulated and from that hypothesis information and data are gathered through experimentation. As a hypothesis is tested through experimentation, new hypotheses may be developed and this process may be repeated until a conclusion is reached. The final step is to share findings with the class or in a larger presentation (Warners \& Myers 3). This approach can be used to problem based learning as an approach to finding a solution 
to the problem. Problem-based learning, however, gives more detail in the nature of the question or problem and the nature of the research. Both PBL and IBI can be integrated into the TBI and CBI classroom as approaches to teaching STEM in the foreign language classroom.

Teaching methods are an important part in combining STEM education content and concepts into the foreign language classroom. Teachers must know how to present materials in the foreign language that relate to specific content while guiding students' language learning through the content. Teachers must be aware of students learning profiles and previous concepts of language learning and content learning and guide students away from traditional notions of the study of language as separate from other content courses. Foreign languages are used as tools in integrated classrooms to communicate meaning, which promotes deeper learning and acquisition by relating language learning to everyday life and by learning the language similar to how students learned their native language. The methodologies presented in this chapter will promote 21 st century skills and will help guide lesson plans and activities discussed in the following chapter. 


\section{Part 6: A General Framework for STEM + Foreign Language Education, with Example Learning Modules for the L2 German Classroom.}

The examples of current STEM education, foreign language education, STEM + Foreign language education, the general framework they follow, and the standards that apply to them as presented in the preceding chapters can be combined with the teaching methods appropriate for integrating STEM in the foreign language classroom in order to create a framework and example learning modules. Previous chapters also discussed societal needs for STEM education and foreign language education and these needs can be addressed through the goals of such frameworks and modules. The goals for educators and outcomes in creating a framework for STEM + foreign language education would be similar to that of the framework for STEM education created by the National Academy of Engineering and National Research Council. The framework would strive to change the current practices of foreign language and STEM field educators and provide educator supports that ultimately will increase educator content knowledge and the pedagogical practices of the STEM field or in the foreign language classroom.

Before creating a framework and dissecting current STEM + foreign language modules, it is necessary to survey the various goals and expectations of the current standards, social needs and programs to outline what the needs are for such a framework and education. First, the US seeks to produce citizens who have a real-world literacy in science, technology, engineering, and mathematics. These citizens can thus make educated decisions relative to their every-day lives and understand current events and affairs using concepts and principles from STEM education and STEM content subjects. 
This means developing everyday problem-solving skills; making educated decisions about healthcare, technologies (computers, transportation, etc.), energy use and conservation' and other life skills. Moreover, the US seeks to produce students who will continue their education in STEM fields and potentially obtain careers in STEM. Similarly, the US recognizes the need for foreign language education to be a part of the US educational system, so that the US can remain a global leader in business, STEM innovation, and education through producing highly trained individuals that can communicate and negotiate ideas in their native language and languages of competing nations.

These goals can be achieved with attention to the standards set for the common core subjects, science education, technology education, and foreign language education. The standards set achievements for students in their respective subjects at the K-12 level, or provide an overall framework for education in their respective fields. STEM education seeks to integrate STEM concepts and principles with one or more subjects under the STEM umbrella or with one or more subjects in another academic field of study. Variations of STEM were created to incorporate other subjects like STEAM, which seeks to incorporate the teaching of STEM subjects with the use of art and artistic representation, and seeks to further integrate core subjects like language arts. Foreign language education is now used as a tool for communication and the study of foreign languages has moved from focusing on the language as content, to learning the language through other content and using language as a tool for communication. Outlining foreign language proficiencies helps instructors create goals for student capabilities when using 
the foreign language to communicate. These concepts, goals, and expectations must be incorporated into the STEM + foreign Language framework to meet the needs of society and education in the US.

As a representation of these goals and expectations of STEM + foreign language education, this paper turns to current examples of learning modules that reflect on these expectations in order to create a framework for creating and implementing STEM + Foreign language education in a broad spectrum of classrooms, and, similar, a broad extent of depth and breadth of content. Excellent examples of such learning modules can be found on the Maryland State Department of Education (MSDE) webpage and are part of the "World Languages Pipelines Project," which "provide a resource for language teachers that is infused with STEM content and designed and taught with an interdisciplinary and problem-solving approach" ("World Languages Elementary STEM Curriculum Modules"). These learning modules provide not only a detailed layout of lessons that are to be used over multiple periods, but they also specify the standards that apply to them and the target proficiency level, and they provide background information for teachers and supplementary materials (handouts, worksheets, etc.). The learning modules available on MSDE's webpage range from grades K-5 and accommodate the lower language proficiency levels that are, necessarily, encountered in K-5 learners. The learning modules are provided in ESOL, Arabic, Chinese and Spanish and are translated to fit each language category and modify the materials accordingly.

One of the published learning modules provided on the MSDE's webpage is titled "Water, Water Everywhere” ("World Languages Elementary STEM Curriculum 
Modules"), and can be found in their website for reference. The learning module is available for the languages previously mentioned at the Junior Novice Low proficiency level and caters to the second grade. The lesson focuses on tackling two of the goal areas of the NSFLE, communication and connections, along with technology and math standards. MSDE uses a framework and learning model relating to STEM education called the " $5 \mathrm{E}$," and these are also mentioned in the learning module. The learning module provides a list of materials needed for the activities, background information for teacher support, detailed lesson plans for the module, teacher reflection worksheets, PowerPoints, and handouts. The lessons within the module are well organized and outline specifically what students should acquire linguistically and comprehend in STEM and other subject areas; for example, in one section students are expected to be able to "name Earth, land, and water" orally ("World Languages Elementary STEM Curriculum Modules"). Naming Earth, land and water is tied into "locating water on Earth" and identifying that "there is more water on Earth" than land ("World Languages Elementary STEM Curriculum Modules"). These goals follow "communication" and "connection" standards of the NSFLE, and standards for earth sciences ("World Languages Elementary STEM Curriculum Modules"). This is one example of combining content knowledge to support other disciplines with low-level proficiency.

The goal of the lesson is for students to acquire language relating to water, more specifically bodies of water (rivers, oceans, etc.) on Earth's surface, and the various states of water (solid, liquid, gas), and for students to understand that there is more water than land on Earth, and in various shapes and forms. Each individual lesson reviews what 
vocabulary students should acquire and what concepts they should learn. The objectives are provided through "I can" statements and also provide performance examples relating to the objectives. The lessons themselves are laid out according to the 5E model, which organizes the lessons through learning concepts: engagement, exploration, explanation, elaboration or extension, and evaluation ("Teaching and Learning: STEM Education"). The engagement section of the lesson poses a problem that sparks student interest; For example, the first lesson of this module students are engaged through the question of thirst and exploring what they already know. Exploration connects the academic subjects to answer a question; again in the first lesson, students connect previously used vocabulary and concepts and relate them to the theme of water. Explanation involves interpreting data and explaining concepts; here in the first lesson of the module students understand the concepts of more and less through visual representation and use that concept to explore if the world has more or less water or land. Elaboration or Extension uses the concepts and skills acquired in the first three stages of the lesson to tackle a new situation; in this lesson, students use colors, counting and estimation, and the concept of more or less to discuss water and land. Finally evaluation assesses knowledge acquired; in this lesson students relate their knowledge to describe the amount of water on a map of the world.

The 5E instructional model used by the Maryland Sate Department of Education and layout of the lessons in the module can be compared to the methods of teaching STEM in the foreign language discussed in the previous chapter. The overall content of the lesson In lesson 1 of the module is integrative STEM, meaning the content integrates 
earth and space sciences, physical science, and formal science content and concepts. The lesson uses authentic texts in the target language in the songs used, handouts, and presentations that are appropriate for the junior novice low learner. The lessons are focused around tasks and involve some pre-task and post-task activities exemplified in the engagement and evaluation stages of the lesson plan. The lessons pose questions about the theme of bodies and stages of water. Students find solutions to these questions through engagement and relate to the students everyday life. For example, the lesson about bodies of water relates back to the Chesapeake Bay, and since the lessons were use in classrooms in Maryland, this is relevant to the local geography. The lessons also tie the states of water to weather, so the students have an understanding of everyday phenomena. The lessons themselves are set up with attention to the scientific method, where the initial phases compile resources and information that lead to a question, the question is tested through experimentation and finally, from the data compiled, a conclusion or further experimentation can be reached.

This learning module is an example of STEM education in the foreign language classroom at a low level of language proficiency with the use of authentic texts. Using this and other MSDE learning modules as examples of existing STEM + foreign language education materials along with the needs and expectations of the US workforce and education, a framework for the integration of STEM + foreign language education can be made. Similar to the framework for STEM education created by National Academy of Engineering and National Research Council, the framework for STEM + foreign language education will have both goals and outcomes for educators and students, nature 
and scope of integrating STEM in the foreign language classroom, and instructional design. The framework will provide a look into how one can integrate STEM education effectively in the foreign language classroom to achieve desired outcomes.

As mentioned above, the goals of a STEM + foreign language program would be to foster the use of foreign language as a tool to communicate meaning specific to the STEM fields at an Intermediate High level of proficiency. The intermediate high level of proficiency is important because it is a speaking level in which students begin to "converse with ease and confidence" and are able to "handle successfully uncomplicated tasks and social situations requiring an exchange of basic information related to their work, school, recreation, particular interests, and areas of competence" (Swender, Conrad and Vicars 7). The goal of Intermediate High proficiencies for writing in the foreign language would produce learners who have a practical working knowledge of the language that correspond with their speaking abilities. Students will also be able to comprehend "sentence length speech [...] in basic personal and social contexts" and "short, non-complex texts" (Swender, Conrad and Vicars 23). This ability can create a highly skilled workforce of graduating students with abilities to problem-solve using STEM principles in the foreign language with specific linguistic competencies in discussing and understanding written or verbal STEM related subjects. Such students would be prepared to work and function in the 21 st century, as they have gained real-life experience using the foreign language, while supporting the concepts of other content courses. Students will see the value of the foreign language as they connect the use of the foreign language to other fields within their education and interests. 
Following the pedagogy of combining STEM Education in the L2 German classroom, the previous example from MSDE, and the framework for creating a STEM + Foreign language, two learning modules and one classroom activity can be found in the appendix of this thesis. The first lesson is titled Energiequellen, or sources of energy. This lesson reviews the sources of energy used in the United States as compared with Germany. The lesson was built around the NGSS High School Disciplinary Idea of "Ecosystems: Interactions, Energy, and Dynamics" and quotes the specific knowledge from the standard to be used in the lesson. Standards from both the CCSSM and STL apply to the content covered in this module and can be found under "STEM Content Standards" of the module. The lesson applies to the Intermediate Low and Intermediate Mid learners of German; however, this could be modified and translated for use in other foreign language classrooms, whether for other languages or other proficiency levels. The lesson could also be modified for higher proficiency levels by seeking to produce higher linguistic accuracy with more content. The lesson begins with interview questions relating to the students' everyday choices for partner conversation and progresses towards an understanding of choices about energy sources. Students finally combine the knowledge in groups and to act out a real-world scenario. The scenario suggests that the students work for a German energy firm and must convince the US to use more renewable energy sources. The module follows the layout of task-based instruction as it contains two pre-task elements, a task, and then post-task element. The module uses Earth Sciences as its content. 
The second module available in the appendix is an example of team-teaching, or at least team-module creation. It involves the lifecycle of a Killifish, similar to lessons about frog lifecycles (from egg, to tadpole, to tadpole with legs, to froglet, to adult frog), the Killifish has a simple lifecycle easily described with visuals, and the Podrabsky Lab of the Portland State University (PSU) Biology Department allowed me to use slides that they have used for various presentations and classes. The PSU Biology Department is currently researching Killifish development under grants from the National Science Foundation and previously the National Institute of Health. This has been an ongoing research project and PSU is one of the only universities in the world to research Killifish. The module is for younger learners of low proficiency levels and involves first reviewing vocabulary, then using the song die Schule vom Killifisch by Gerhard Schöne to introduce the theme of Killifish, then explore the development of a specific kind of Killifish, and finally the students would reproduce the cycle with cutouts and drawing. This is an example of combining significant projects within Portland State University as an example of interdisciplinary support between faculty and departments. This can be done with simpler concepts through departmental support in high schools with faculty that specialize in K-12 STEM field education. The lesson uses standards Life Sciences standards and various standards from the NSFLE. The lesson it aimed towards K-5 classrooms and for students at the Novice Mid to High proficiency levels in German. In addition to the two learning modules created by this thesis, an activity that can be applied anytime in class relating to technology is provided in the appendix. This activity is an example of mathematical modeling, as it uses a situation for students to 
calculate distance, material, and time used for traveling. These example activities can me implemented in classrooms that do not allow for the time of a full lesson. The students explore different German automobile models and statistics to calculate their results while driving in German speaking countries in the mathematical modeling situation, making the lesson culturally relevant.

In order to create modules, activities, and lesson plans similar to what has been described in this chapter and implement them in the foreign language classroom, foreign language educators would need to improve upon their current pedagogical knowledge and probably their content knowledge; therefore, the goals of Language educators would also be similar to that of the framework provided by the National Academy of Engineering and National Research Council. Educators would modify their language instruction to reflect current needs in education and the foreign language education community by incorporating different standards and activities in their lessons like those described in these chapters. Also, educators would need to adjust their instruction to focus on communication and more specifically, communication of content relevant to students' education, goals, and life. Educators would use authentic materials, as discussed as appropriate for $\mathrm{CBI}$, and integrate the foreign language learning with the current NSFLE standards and other content standards. Additionally, collaboration among departments is desired as one possibility for content-based instruction of foreign language, which involves adjunct educator participation as exemplified in the Killifish module. The collaboration could be STEM educators familiar with or fluent in the native language or STEM educators assisting with foreign language educators understanding of 
the STEM content and concepts. Outcomes for educators of STEM + Foreign language education would be a new workforce of highly skilled educators with increased foreign language and pedagogical skills willing to collaborate and break the traditional academic silos.

The previous modules created by this chapter's framework involves teaching different academic content areas in the foreign language; therefore, the nature and scope of STEM + foreign language education should use CBI to focus the lesson on the content, while using the foreign language. As described by the National Academy of Engineering and National Research Council, one subject dominates in the instruction and the integrated concepts and practices from other subjects should be used to support the learning and content. For example, in the foreign language classroom a text is given with complex grammatical subjects; in order to understand the content of the text, the new grammar theme is introduced implicitly or explicitly to support meaning. In this example, linguistic structure is used to support the targeted content, as opposed to a language course focusing on structure of the language. Another example could be learning vocabulary relating to numbers in order to understand data relating to a STEM theme, or learning vocabulary relating to an Internet search so students can describe the process of an Internet search in the foreign language. These activities can drive a STEM + foreign language curriculum or course, used as supplemental activities in the foreign language classroom, or used as single or multiple lesson units.

Educator supports that detail information about pedagogy, instruction, and content knowledge must be provided in order to achieve the goals of such a program with the 
previously mentioned outcomes. Already there are grant projects and online resources that provide examples of such programs. They offer information about instruction, background information on the STEM content, and they provide detailed learning modules. A more comprehensive, concrete guide and/or program would be effective to support educators new to this concept; however, as the case with STEM education, since the concept is new, there are limited resources and the STEM + foreign language education concept is still in development.

The framework created by this thesis is intended to support further creation and integration of core content in the foreign language classroom. The examples provided are untested, but provide a bases for ideas and the development of new curricula, activities, lessons, etc. that combine STEM and German. Many other supports are needed for teachers and schools to apply these frameworks, but the implementation of the lessons described will create students that can function in the real world and the growing global community that the United States is a part of. Columbia River High School is now practicing STEM education in their German classrooms at a limited level as a result of this thesis. Their International Baccalaureate course covers sustainability and humans effect on nature. The lower level German classes practice number and math problems in the context of new vocabulary and grammar. 


\section{Part 7: Assessing Students' STEM + German performance}

Now that a framework for STEM + foreign languages has been established, how to assess student's performance in STEM + foreign language education must also be created as a part of this education. The goals and outcomes of a STEM + foreign language education that were discussed in the previous chapter and should lay out an overall assessment plan for students' outcomes and performances, which will help guide the individual assessment methods of more specific classroom activities. Individual lesson, assignment, activity, and/or project assessment will have to take standards and pedagogical assessment methods into consideration.

Students' language performances should be assessed according to the ACTFL Proficiency Guidelines, ranging from Novice Low to Distinguished. Students capabilities in reading, writing, speaking, and listening can be assessed according to these guidelines, and the reader can outline specific tasks that students can accomplish with the language they have acquired through the activity. The general classroom proficiency should be established before assessment goals are created. Students can be expected to accomplish new tasks at their established level, or they can be expected to accomplish tasks at a higher level with the new language acquired in the classroom. STEM + foreign language education should aim at accomplishing Intermediate High proficiency linguistic capabilities as a general goal and activities should build on the students linguistic capabilities.

Since language is a acquired and not learned, as discussed in the previous chapters, tasks should be described as students assessment goals rather than the student's 
use of specific linguistic structures. For example, a high school classroom may be exploring the NGSS Disciplinary Core Idea HS-LS2-7 "Ecosystems: Interactions, Energy, and Dynamics," as discussed in the previous chapter and exemplified in the lesson plan provided in the appendix. This standard expects students to understand human impact on earth's ecosystems and from this knowledge students should be able to create solutions that reduce human impact on the environment and biodiversity (National Science Teachers Association, 2012). Students can be given resources in the target language that discuss human activities that effect earth's ecosystems; for example, the standard discusses dams, urbanization, and dissemination of invasive species. The lesson conducted around this resource should focus on the student's proficiency level. If the students are able to read at the Intermediate Low proficiency level, then the text provided should be accessible to that level of learner or of a comprehendible higher level; for example, Intermediate Mid. For the text to be accessible to the learner, it should not be of a proficiency that is too advanced for the learner to comprehend. The task should focus on the students' comprehension of the text and from that producing language at the Intermediate Low to High proficiency level and students should be assessed according to their ability to accomplish the task at the Intermediate Low to High proficiency level in whatever they are asked to produce orally, written, listening comprehension checks, or reading comprehension checks.

The assessments can use the models provided by the ACTFL Proficiency Guidelines relating to the activity. For example, the ACTFL Proficiency Guidelines state that the Intermediate Low speaker should be able to handle some "uncomplicated 
communicative tasks" and communicate by "combining and recombining what they know and what they hear from their interlocutors into short statements and discrete sentences" (Swender, Conrad and Vicars 7). Hesitancy, pauses, inaccuracies, reformulations, and self-corrections are typical and should be allowed, as they are characteristics of the intermediate low learner. The students speaking assessments should follows these guidelines and if they are able to relate their text to the theme of the lesson at the proficiency level of the overall class, they should receive full points. If students fall below the average or expected proficiency level of the class, they should not receive full points. Reading, writing, and listening assessments should follow the same guidelines. Self-assessments are also efficient in the foreign language classroom as students can learn what is expected of them, what they need to achieve a task at a high level and of high quality. Self-assessments can develop many desirable traits in a student. For example, self-assessments can support autonomous learning and responsible learning, where students take responsibility for their learning as opposed to relying on their teacher for assessments. Self-assessments, in this case, can outline the language students are expected to know and how they are expected to use the language; therefore, students understand their performance and gain an understanding of how they learn a language and are expected to use it at a low level of proficiency. An effective self-assessment template created by Mats Oskarsson that can be applied to any language classroom is available in his book Approaches to Self-assessment in Foreign Language Learning.

These methods of assessment can assist an educator in evaluating what the students have acquired and what needs additional attention. Self-assessments can allow 
students to openly communicate with educators about the lesson and their learning experience, this will help educators develop materials and cater to students' needs. This will also help educators understand what needs extra attention. Students can understand their level of linguistic capabilities through learning about the proficiency levels they are being assessed by and they can understand how to preform, practice, and study for future assessments.

Along with the linguistic assessment, students ability to accomplish basic tasks pertaining to the STEM content must be evaluated. The National Academy of Engineering and National Research Council created a few guidelines for STEM education assessment that accompany the Integrative STEM education framework. The committee suggested that assessments should measure discipline specific and integrated learning; this means, the assessment should measure students understanding of concepts and themes from whatever specific discipline the experience is focused on. The assessment should also measure the level of integrated learning, or how the student can apply the concepts and themes of a certain discipline to real world, everyday situations outside of the content specific classroom. For example, the foreign-language classroom using concepts from the NGSS's disciplinary idea HS-LS2 Ecosystems: Interactions, Energy, and Dynamics (National Science Teachers Association, 2012) should, for example, be able to "design, evaluate and refine a solution for reducing the impact of human activities on the environment and biodiversity," which is an example of one outcome, out of many, taken directly from the standard. In the STEM-oriented language classroom, this task need not be - and sometimes should not be - pitched at such a high 
levelas the words "design," "evaluate," or "refine" initially imply.The task of the Energiquellen module tackles this standard by asking students to create a pamphlet supporting the use of renewable energy, which should, in the end, discuss the impact of other resources when compared to renewable resources of energy. In addition to this content and integrative statement for assessment, the assessment can test their ability to use the foreign language in this situation relating to their respective linguistic capabilities. For example, an assessment for the Intermediate Low learner could cover this aspect of the standard in addition to their written linguistic capabilities in the following can-do statements; "The student is able to create short statements in present time based on the structures and vocabulary learned in this lesson. The statements should discuss the impact of energy resources and suggest a solution for the impact on the environment and humanity of non-renewable sources of energy. Basic errors in grammar, word choice, punctuation, and spelling are acceptable; however, the writing used should be generally understood by natives." These statements combine and element of the NGSS disciplinary idea HS-LS2-7 in addition to the linguistic capabilities of the learner. Students achieving more than what is described above should be marked with higher achievement points for this specific lesson and student unable to complete these tasks should be marked lower for this method of assessment. The previous assessment statement would mark the average of the class, and for higher achievements in proficiency and content knowledge and application, the student would be placed above others in an assessment scale. Assessment of STEM + foreign language education activities and abilities involves the 
interdisciplinary components of the education, the linguistic achievement or deficiency, and assessment of STEM content learned.

Larger scale assessments should follow similar method and assessment pattern. Like the ACTFL Proficiency guidelines, general guidelines for the use of the language in relation to STEM content should be provided for programs hoping to adopt this method. These guidelines would state students varying abilities and their ability to apply the linguistic capabilities to different STEM fields. For example, the Novice High learner would be expected to add, subtract, multiple, and divide in the target language, and complete these tasks with limited hesitancy in reproducing numbers. This large-scale assessments would need to provide grade-appropriate tasks; for example, students in $1^{\text {st }}$ grade would not be expected to multiply in the foreign language as this is taught at a higher grade level. Assessments can be made for the lesson plans available in the appendix of this thesis, but large-scale assessments are out of the scope of this thesis and may be continued in a later paper.

Assessments for STEM + foreign language education should outline student capabilities by can-do statements that address specific abilities students have acquired and can use to accomplish whatever assessment task is asked of them. Assessments can include specific examples from the task they are asked to accomplish and should assess the linguistic capabilities of the student, the content knowledge of the STEM discipline, and the students' ability apply the knowledge to various situations. 


\section{Part 8: Discussion and Conclusion}

STEM Education is a relatively new concept that is booming with potential, yet lacks definition. Foreign language education has undergone numerous changes and developments. Research about current programs has led to the creation of frameworks for STEM education and helped with the creation of STEM + foreign language education that this thesis has to offer. Both fields of study, the STEM fields and foreign languages, are facing issues with student success, motivation, and enrollment, but with the support of pedagogical and educator innovation, the possibility of recreating student interest through integration is a potential result of this change in content instruction. Both subjects are important to society as they develop skills in their learners that can foster real world application of content knowledge taught in K-12, and in some cases K-16, foreign language and STEM classrooms.

Additional discussion in this topic area lies in the success of new innovative teaching methods in the area of minority students, alternative learning styles, and women succeeding in STEM fields and foreign language classrooms. Research already shows some success in these methods reaching a diverse range of students and their success in the classrooms. For example, Torp and Sage discuss an example of PBL, a method of STEM education, and the success of an elementary aged special education student (6-7). The project, as mentioned in Part 5 of this paper, was to explore and create a guide based off of a problem with an unhealthy flower garden. The result of the PBL led the special education student to create "instructions that included 10 necessary components for healthy plant growth: 'soil, seeds, water, fertilizer, sun, rain, carbon dioxide, 
respiration/breathe, chlorophyll/food, and space to grow" from her initial instructions, which included "four pictures, with little accompanying information" (Torp \& Sage 7). Isreal, Maynard, and Williamson suggest that students with diverse learning needs struggle with traditional STEM instruction because it "focuses on abstract concepts," and uses "difficult vocabulary within complex expository texts," and because traditional school schedules limit subject integration (18). In addition to research supporting the support of STEM education with special needs students, one of the goals of many existing STEM education programs as discussed by the National Academy of Engineering and National Research Council is to increase interest in the STEM fields in "girls and certain minorities" (35) and for them to develop what has been defined as "STEM identity" and interest. STEM education has many benefits, and combining these methods that support all student success with language education could be highly beneficial if researched and tested.

The issue of STEM and foreign languages is recent. AATG and other language organizations are making recent efforts to incorporate other subjects and content in the language-learning environment of their classrooms. This is an effort to further communicative language teaching and support interest in foreign language education in the US. For example, AATG is offered grants for teachers interested in incorporating STEM/MINT (MINT - Mathematik: Mathematics, Informatik: Computer Sciences, Naturwissenschaft: Science, Technik: Technology - is the German acronym for STEM fields in Germany) in their teaching. 
Finally, the implementation of STEM in the German classroom can lead to students support in their potential to receive scholarships and in career preparation. Deutscher Akademischer Austauschdienst (DAAD) provides grants and scholarships for STEM related studies. For example, DAAD offers a RISE scholarship for undergraduate students in the fields of biology, chemistry, physics, earth sciences, and engineering. The scholarship allows students to work with research groups, research institutions, and doctoral students in Germany for two or three months in the summer. Students with linguistic skills able to communicate STEM related concepts and ideas might support their application. The career possibilities for STEM education can involve international business and working abroad for those interested and students with linguistic skills in the STEM fields will help them improve their resumes and set them apart from other applicants unable to communicate effectively in the native language.

This project will continue the research in STEM education and foreign language education innovation and any effort to continue bettering the quality of education for all students. I hope to also help German and other Foreign Language programs with enrollment and support for their programs. The effort that this research supports involves a shift in language education from traditional methods that divides foreign languages from other core subject to an interdisciplinary, inclusive, and practical approach that views the study of foreign languages as a tool that can better the US's global standing and its citizens. 


\section{Works Cited}

Common Core State Standards Initiative. "About the Standards." Common Core State Standards Initiative About the Standards Comments. Common Core State Standards Initiative, n.d. Web. 30 Dec. 2014.

Altschuler, Glenn. “America's Foreign Language Deficit.” Forbes. Forbes Magazine. 27 Aug. 2012. Web. 6 July 2014.

American Association of Teachers of German. "Stem Articulation Grant." AATG, 2013. Web. 9 July 2014.

American Association of Teachers of German, North Carolina Chapter. "Proposal wins STEM Articulation Grant from AATG” NCAATG. n.d. Web. July 9, 2014.

National Standards in Foreign Language Education Project, Yonkers, NY. Standards for Foreign Language Learning Preparing for the 21 st Century. S.1.]: Distributed by ERIC Clearinghouse, 1996. Print.

Swender, Elvira, Daniel J. Conrad, and Robert Vicars. "ACTFL proficiency guidelines 2012." (3rd ed.). Alexandria,VA: American Council for the Teaching of Foreign Languages. 2012. Web July 31, 2014.

Angier, Natalie. "STEM Education Has Little to Do With Flowers." The New York Times. The New York Times, 04 Oct. 2010. Web. 31 May 2014.

Assefa, Shimelis G., and Abebe Rorissa. "A Bibliometric Mapping of the Structure of STEM Education Using Co-word Analysis." Journal of the American Society for Information Science and Technology 64.12 (2013): 2513-536. Web.

Breiner, Jonathan M., Shelly Sheats Harkness, Carla C. Johnson, and Catherine M. Koehler. "What Is STEM? A Discussion About Conceptions of STEM in Education and Partnerships." School Science and Mathematics 112.1 (2012): 311. Web.

Brandl, Klaus. Communicative Language Teaching in Action: Putting Principles to Work. Upper Saddle River, NJ: Pearson Prentice Hall, 2008. Print.

Bybee, R. W. "What Is STEM Education?" Science 329.5995 (2010): 996. Web.

"Common Core State Standards Initiative Standards-Setting Criteria." www.corestandards.org. Common Core State Standards Initiative. n.d. Web. 30 July 2014. 
National Academy of Engineering and National Research Council. STEM Integration in K-12 Education: Status, Prospects, and an Agenda for Research. Washington, DC: The National Academies Press, 2014.

Institute of Medicine, National Academy of Sciences, and National Academy of Engineering. Rising Above the Gathering Storm: Energizing and Employing America for a Brighter Economic Future. Washington, DC: The National Academies Press, 2007.

"Development Process." Development Process | Common Core State Standards Initiative. Common Corse State Standards Initiative. Web. 30 July 2014.

Ecke, Peter. "The State of German in the United States: A Statistical Portrait and a Call for Teachers." German as a Foreign Language (2011): 54-83. German as a Foreign Language Journal. Web. 30 July 2014.

"Ein Heißer Supercomputer." Politik \& Wirtschaft. Deutsch Perfekt, 20 July 2012. Web. 9 June 2015.

"Elementary." NGSSNSTA Hub. National Science Teachers Association, n.d. Web. 30 July 2014.

Ellis, Rod. "The Methodology of Task-Based Teaching." Asian EFL Journal 11.5 (2006): 79-101. Web. 30 July 2014.

Ellis, Rod. Task-based Language Learning and Teaching. Oxford, U.K.: Oxford UP, 2003. Print.

Felder, Richard M., and Eunice R. Henriques. "Learning and Teaching Styles In Foreign and Second Language Education." Foreign Language Annals 28.1 (1995): 21-31. Web 25 July 2014.

Grabe, William. Fredricka L. Stoller "Content-Based Instruction: Research Foundations." The Content-based Classroom: Perspectives on Integrating Language and Content. n.d. University of Minnesota. Regents of the University of Minnesota. Web. 2 Jan. 2015.

Gonzales, Dana. "STEM Progress In Katrina's Wake." Tech Directions 67.8 (2008): 2326. ERIC. Web. 2 Jan. 2015. 
Guidelines Pyramid. Digital image. ACTFL Proficiency Guidelines 2012 | American Council on The Teaching of Foreign Languages. American Council on the Teaching of Foreign Languages, n.d. Web. 30 July 2014.

Heo, Yoon. “Content-based instruction.” TESL Working Paper Seriies (2006): 25-32. Web.

Higgs, Theodore V. Teaching for Proficiency: The Organizing Principle. Lincolnwood, IL, U.S.A. (4255 W. Touhy Ave., Lincolnwood 60646-1975): National Textbook, 1984. Print.

Hoachlander, Gary, and Dave Yanofsky. "Making STEM Real." What Students Need to Learn 68.6 (2011): 60-65. Web. 2 Jan. 2015.

Hung, Woei, David H. Jonassen, and Rude Liu. "Problem-based Learning." Handbook of Research on Educational Communications and Technology 3 (2008): 485-506. Web. 2 Jan. 2015.

“Integrative STEM Education”. Integrative STEM Education. n.d.Web 9 July 2014.

International Technology Education Association. "Standards for technological literacy: Content for the study of technology." Reston, VA: Author. 2000. Web 9 July 2014.

Israel, Maya, Kathie Maynard, and Pamela Williamson. "Promoting Literacy-Embedded, Authentic STEM Instruction For Students With Disabilities And Other Struggling Learners." TEACHING Exceptional Children 45.4 (2013): 18-25. ERIC. Web. 2 Jan. 2015.

Kennedy, Michael J., and Jade Wexler. "Helping Students Succeed Within SecondaryLevel STEM Content." TEACHING Exceptional Children 45.4 (2013): 26-33. Web. 2 Jan. 2015.

Krajcik, Joseph S., Phyllis C. Blumenfeld, Ronald W. Marx, and Elliot Soloway. "A Collaborative Model for Helping Middle Grade Science Teachers Learn ProjectBased Instruction." The Elementary School Journal 94.5 (1994): 483. Web. 2 Jan. 2015.

Krashen, Stephen D. Second Language Acquisition and Second Language Learning. Oxford: Pergamon, 1981. Print. 
Liskin-Gasparro, Judith E. "The ACTFL Proficiency Guidelines and the Oral Proficiency Interview: A Brief History and Analysis of Their Survival." Foreign Language Annals 36.4 (2003): 483-90. Web. 2 Jan. 2015.

Murphy, J. "Task-based Learning: The Interaction between Tasks and Learners." ELT Journal 57.4 (2003): 352-60. Web. 2 Jan. 2015.

Manuel, Diane. "Educators Revisit 20-year-old Study of Foreign-language Education in the U.S." Stanford Report. Stanford University, 9 June 1999. Web. 8 Nov. 2014.

National Research Council. Monitoring Progress Toward Successful K-12 STEM Education: A Nation Advancing?. Washington, DC: The National Academies Press, 2013.

National Research Council. Rising Above the Gathering Storm, Revisited: Rapidly Approaching Category 5. Washington, DC: The National Academies Press, 2010.

National Research Council. Next Generation Science Standards: For States, By States. Washington, DC: The National Academies Press, 2013. Web 30 July 2014.

National Defense Education Act of 1958: H.R. 13247, 85th Congress, Public Law 85864, September 2, 1958: Reports, Bills, Debate and Act.

National Governors Association Center for Best Practices \& Council of Chief State School Officers. Common Core State Standards for English language arts and literacy in history/social studies, science, and technical subjects. Washington, DC: Authors. 2010. Web. 30 July 2014.

National Governors Association Center for Best Practices \& Council of Chief State School Officers. Common Core State Standards for Mathematics. Washington, DC: Authors. 2010. Web. 30 July 2014.

"National Science Board." National Science Board - About. National Science Foundation, 1 Apr. 2013. Web. 8 July 2014.

National Science Board (U.S.). Preparing the next generation of STEM innovators: Identifying and developing our nation's human capital. National Science Foundation. 5. May 2010. Web. 8 July 2014.

Next Generation Science Standards Executive Summary. Next Generation Science Standards for States by States. 2013. Web 30 July 2014. 
Oskarsson, Mats. Approaches to Self-assessment in Foreign Language Learning. Oxford: Published for and on Behalf of the Council of Europe by Pergamon, 1980. Print.

Panetta, Leon E. Foreign language education: If 'scandalous' in the 20th century, what will it be in the 21st century. US Department of Defense. 1999.

Peters-Burton, Erin E., Sharon J. Lynch, Tara S. Behrend, and Barbara B. Means. "Inclusive STEM High School Design: 10 Critical Components." Theory Into Practice 53.1 (2014): 64-71. Web. 2 Jan. 2015.

"Problems as Possibilities: Problem-based Learning for K-12 Education." Choice Reviews Online 36.07 (1999): 36-4042. Web.

Richards, Jack C., and Theodore S. Rodgers. Approaches and Methods in Language Teaching: A Description and Analysis. Cambridge: Cambridge UP, 1986. Print.

Salazar, Patricia. "Comprehensible input and learning outcomes." Second Conference for the Promotion of Research at the FCHS (1996): 1-6.

Sanders, Mark. "STEM, STEM Education, Stemmania." Technology Teacher 68.4 (2009): 20-26. ERIC. Web. 2 Jan. 2015.

Schwartz, Peter, Stewart Mennin, and Graham Webb. Problem-Based Learning: Case Studies, Experience and Practice = Case Studies of Teaching in Higher Education. London: Kogan Page, 2001. Print.

Simkovic, M. Risk-Based Student Loans. Washington and Lee Law Review, 70.1(2013): 549-549. Web. 30 November 2014.

Simon, P. (1980). The tongue-tied American: confronting the foreign language crisis. New York: Continuum.

Stryker, Stephen B., and Betty Lou. Leaver. Content-based Instruction in Foreign Language Education: Models and Methods. Washington, D.C.: Georgetown UP, 1997. Print.

“Teaching and Learning: STEM Education." School Improvement in Maryland. Maryland State Department of Education. 2014. Web 31 July 2014.

“Three Dimensions." Next Generation Science Standards for States, by States. Next Generation Science Standards. n.d. Web. 30 July 2014. 
Torp, Linda, and Sara Sage. Problems as Possibilities: Problem-Based Learning for K-12 Education. 2nd ed. Alexandria, VA: Association for Supervision \& Curriculum Deve, 2002. 102. Print.

U. S. Department of Education. Maryland Pairs World Languages with STEM to Increase 21st-Century Skills. DoED. Web. 30 July 2014.

Warner, Anna, and Brian Myers. "What Is Inquiry-Based Instruction?" University of Florida IFAS Extension (2011): 1-3 Web. 2 Jan. 2015.

White, David W. "What Is STEM Education and Why Is It Important?" Florida Association of Teacher Educators Journal 1.14 (2014): 1-9. Web. 2 Jan. 2015.

Wissehr, Cathy, Jim Concannon, and Lloyd H. Barrow. "Looking Back at the Sputnik Era and Its Impact on Science Education." School Science and Mathematics 111.7 (2011): 368-75. Web. 2 Jan. 2015.

"World Languages Elementary STEM Curriculum Modules." Maryland State Department of Education: Preparing World Class Students. Maryland State Department of Education. 2014. Web 30 July 2014.

Wynn, Toni, \& Harris, Juliette "Toward a STEM + Arts Curriculum: Creating the Teacher Team.” Art Education, 65.5 (2012): 42-47. Web. 30 July 2014.

Yakman, Georgette. "What is the point of STE@M? - A Brief Overview." Steam: A Framework for Teaching Across the Disciplines. STEAM Education. 7. Aug. 2010. Web. 2 Jan 2015. 


\section{Appendix A: STEM + German Module, Das Leben eines Killifischs}

\section{Grade: K-5 \\ Proficiency Level: Novice Mid - Novice High}

Goals: Using the power point provided and classroom discussion and presentation students will understand various major forms of energy consumption. They will discuss their daily personal decisions that are either ecofriendly or sustainable and what they and their community can do better. Students will create informative pamphlets for presentation about energy sources.

Objectives: Students will use the new vocabulary to describe the decisions they make that impact their environment. They will be able to describe data represented on a graph in the target language.

\begin{tabular}{|l|l|}
\multicolumn{1}{|c|}{ STEM Content Standards } & \multicolumn{1}{c|}{ Foreign Language Standards } \\
NGSS - 3-LS1 From Molecules to & NSFLE 5C \\
Organizsms: Structures and & Communication: 1.1, 1.2, 1.3; \\
Processes & through oral and written \\
- Core Ideas) 3-LS1.B: Growth & conversation, interpretation, and \\
and Development of & presentations students \\
Organisms & communicate information, \\
& concepts, ideas, opinions, and \\
NGSS - 3-LS4 Biological Evolution: & emotions relating to the theme of \\
Unity and Diversity & lifecycles. \\
(Core Ideas) 3-LS4.C & Connections: 3.1; reinforce and \\
Ecosystem Dynamics, & further knowledge of other \\
Functioning, and Resilience & disciplines (life sciences, natural \\
(Core Ideas) 3-LS4.C & sciences) through use of the \\
Adaptation & foreign language. \\
& Comparisons: 4.1; Students \\
& recognize words used in German \\
& to describe lifecycles as they \\
& have in English. \\
& Communities: Students use \\
& language in school setting. \\
\hline
\end{tabular}




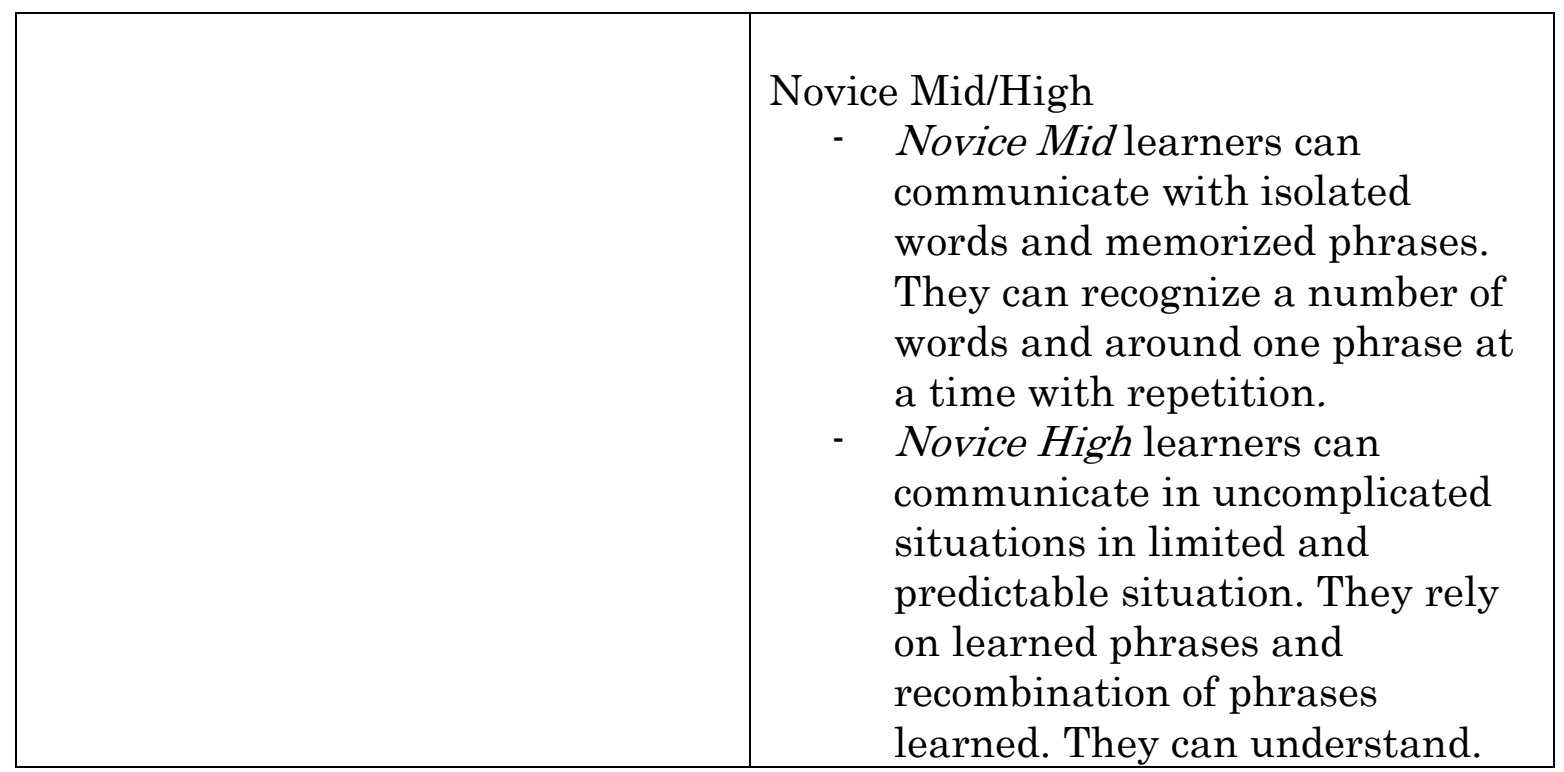


Duration 90 minutes (can be divided into 3 separate 30 minute lessons; PreTask - Introduction, Pre-Task - Discussion, Task stage with some revision of previous materials)

\begin{tabular}{|c|c|}
\hline Objectives & $\begin{array}{l}\text { Students will identify the lifecycle of a } \\
\text { south American/African Killifish and the } \\
\text { different stages of the Killifish. } \\
\text { Students will recognize that the } \\
\text { American/African Killifish relies on the } \\
\text { time of year and environment to develop. } \\
\text { - Students respond and use phrases and } \\
\text { words from the lesson to describe the } \\
\text { lifecycle of the American/African Killifish } \\
\text { and the environment it lives in. } \\
\text { - Students maintain utterances according to } \\
\text { the Novice High/Mid models of } \\
\text { proficiency. }\end{array}$ \\
\hline $\begin{array}{l}\text { Pre-Task } \\
\text { Introduction }\end{array}$ & $\begin{array}{l}\text { 1) Start the lesson by introducing vocabulary to } \\
\text { be use in the song Die Schule vom Killifisch by } \\
\text { writing the word in a visible place and asking } \\
\text { the following questions: } \\
\text { - (Lehrer/Leherin) Wer ist hier eine } \\
\text { Lehrerin? } \\
\text { - (schwimmen) Alle schwimmen! - Mime } \\
\text { swimming for class } \\
\text { - (Schule) Wo finden wir eine Schule? } \\
\text { - (Unterricht) Wann haben wir } \\
\quad \text { Deutschunterricht? } \\
\text { - (lernen) Was lernen wir auf der Schule? } \\
\text { - (Fisch) Was lebt im Wasser? } \\
\text { 2)If your classroom has a Killifish as a pet - then } \\
\text { Use it to sing this video. If not, use the video } \\
\text { provided. Introduce the lesson today by } \\
\text { mentioning the theme. }\end{array}$ \\
\hline
\end{tabular}




\begin{tabular}{|c|c|}
\hline & $\begin{array}{l}\text { Wir lernen heute über Fische! Wer hat ein } \\
\text { Fisch als Haustier? Wer hat eine } \\
\text { Aquarium zuHause? (can extend by } \\
\text { asking what kind of fish, how big, etc...) } \\
\text { - Was sind einige beliebte Aquarienfische? } \\
\text { 3) (slide 1) Start the PPT by reviewing } 3 \text { common } \\
\text { Aquarienfisch ending with the Killifisch. Ask } \\
\text { students questions and when they respond in } \\
\text { English, give the German word/pronunciation } \\
\text { and have students repeat them. } \\
\text { - Was ist das? } \\
\text { - Sehr gut/Ausgezeichnet/Genau! Das ist } \\
\text { ein Goldfisch/Kampffisch/Killifisch } \\
\text { 4) (slide 4) Guide lesson toward Killifish through } \\
\text { the song. } \\
\text { - Sehr gut! Heute lernen wir den Killifisch } \\
\text { kennen! } \\
\text { - Möchten wir ein Killifischlied singen? } \\
\text { - Hier Hören wir ein Lied über Killifisch! } \\
\text { Let the song play once through and then provide } \\
\text { the students with the text for the song and play } \\
\text { it again with them singing the last line of each. } \\
\text { Everyone sing together, line by line or whole } \\
\text { song. }\end{array}$ \\
\hline $\begin{array}{l}\text { Pre-Task } \\
\text { Lifecycle }\end{array}$ & $\begin{array}{l}\text { 1) (slide 5) The lesson transitions with the song } \\
\text { into killifisch discussion. } \\
\text { - Woher kommt der Killifisch? (asks } \\
\text { students) } \\
\text { - Kommt der Killifisch aus Amerika, } \\
\text { Südamerika, Afrika, Südeuropa, Asien } \\
\text { und dem Nahen Osten? Ja! (repeat and } \\
\text { point out geopraphical locations) } \\
\text { (slide 6-7) Leads to discussion of specific annual }\end{array}$ \\
\hline
\end{tabular}


Killifish from South America and Africa. Have students repeat/chant new vocabulary.

- Die Killifische aus Südamerika und Afrika sind interresant, schön, bunt (other Adjektiven)

- Wo wohnen die Killifische aus Südamerika und Afrika? ○ In Pfützen und Tümpel!

2) Students identify issues of dry season and wet season for the Killifish.

- In Südamerika und Afrika regnet es viel?

- Es gibt eine Regenzeit und eine Trockenzeit

- Wo wohnen die Killifische, wenn es regnet? Wenn es trocken ist?

3) (slide 7) The lifecycle of the annual Killifish is discussed here

- Die Killifische wohnen in (get the students to day word for puddle) in (students say regions where Killifish live in Puddles)

- Die Killifisch leben erst als Fischei (pointing to the egg stage: diapause I/II/III), und dann werden sie Larven. Endlich die letzte phase als erwachsene Killifische. Die erwachsenen Killifische legen neue Eier und der Zyklus geht weiter.

- Repeat the stages of the fish with the students and have them repeat it. Erst... und dann.. und endlich... und die erwachsenen Killifische legen...

- Aber was passiert, wenn die Trockenzeit kommt?

○ Die erwachsenen Killifische stecken ihre Eier in die Erde.

○ Wenn die Pfützen und Tümpel 


\begin{tabular}{|c|c|}
\hline & $\begin{array}{l}\begin{array}{l}\text { austrocknen, bleiben die Eier da. } \\
\text { Wenn es wieder regnet, hecken die } \\
\text { Eier und sie werden Larven und } \\
\text { dann später erwachsene Killifische. }\end{array} \\
\text { 4) Show video from minute 0:30 - 1:18: } \\
\text { https://www.youtube.com/watch?v=4sy3R3f_GCY } \\
\\
\text { - Narrate the video: Hier ist eine Pfütze von } \\
\text { einem Elefants Fußabdruck in Afrika. } \\
\text { Hier wohnen der Killifish. Hier sind die } \\
\text { Killifischeier. Die Eier hecken, erst } \\
\text { Larven, und dann erwachsene Killifische. } \\
\text { After the video. Später trocknet das } \\
\text { Wasser aus und die neue Eier warten, bis } \\
\text { es regnet. }\end{array}$ \\
\hline $\begin{array}{l}\text { Task-Organize the } \\
\text { Lifecycle. }\end{array}$ & $\begin{array}{l}\text { 1) Divide students into groups of } 2 \text {. Give each } \\
\text { group the word cutouts and images for } \\
\text { organizing. } \\
\text { 2) Direct students to organizing the lifecycle of a } \\
\text { fish, by first reading the words and repeating } \\
\text { them with the class and allowing students to } \\
\text { match the words with the appropriate images. } \\
\text { 3) While the students create the lifcycles with } \\
\text { the images, draw a word cloud on the board with } \\
\text { the main words of the lesson: Killifisch, } \\
\text { Lebenszyklus, Pfützen, Tümpel, Regenzeit, } \\
\text { Trockenzeit, Ei, Larve, erwachsene Killifisch. } \\
\text { Give the students paper and drawing materials } \\
\text { and allow them to draw the cycle they created } \\
\text { and learned about. }\end{array}$ \\
\hline
\end{tabular}




\section{Extensions:}

This lesson can be extended into observations about our own lifecycles and the language to describe our stages of life or other organisms' stages of life in a similar model. Fetus->Adult

\section{Background information:}

There are many different kinds of Killifish. This lesson focuses on the Annual Killifish (Austrofundulus limnaeus) found in Venezuela to explore the lifecycle of fish. The Austrofundulus limnaeus has a similar lifecycle to Killifish found in African and other South American countries.

Podrabsky Lab at Portland State University: http://www.pdx.edu/podrabsky$\underline{\text { lab/ }}$

Wikipedia page on General Killifish information:

http://en.wikipedia.org/wiki/Killifish

Information about the annual Killifish Lifecycle: http://infolific.com/pets/fishin-the-wild/killifish-life-cycle/

German Language Wikipedia Resource (see Verbreitung):

http://de.wikipedia.org/wiki/Eierlegende_Zahnkarpfen 
Images from PPT to cut out and use for students organizing the lifecycle.
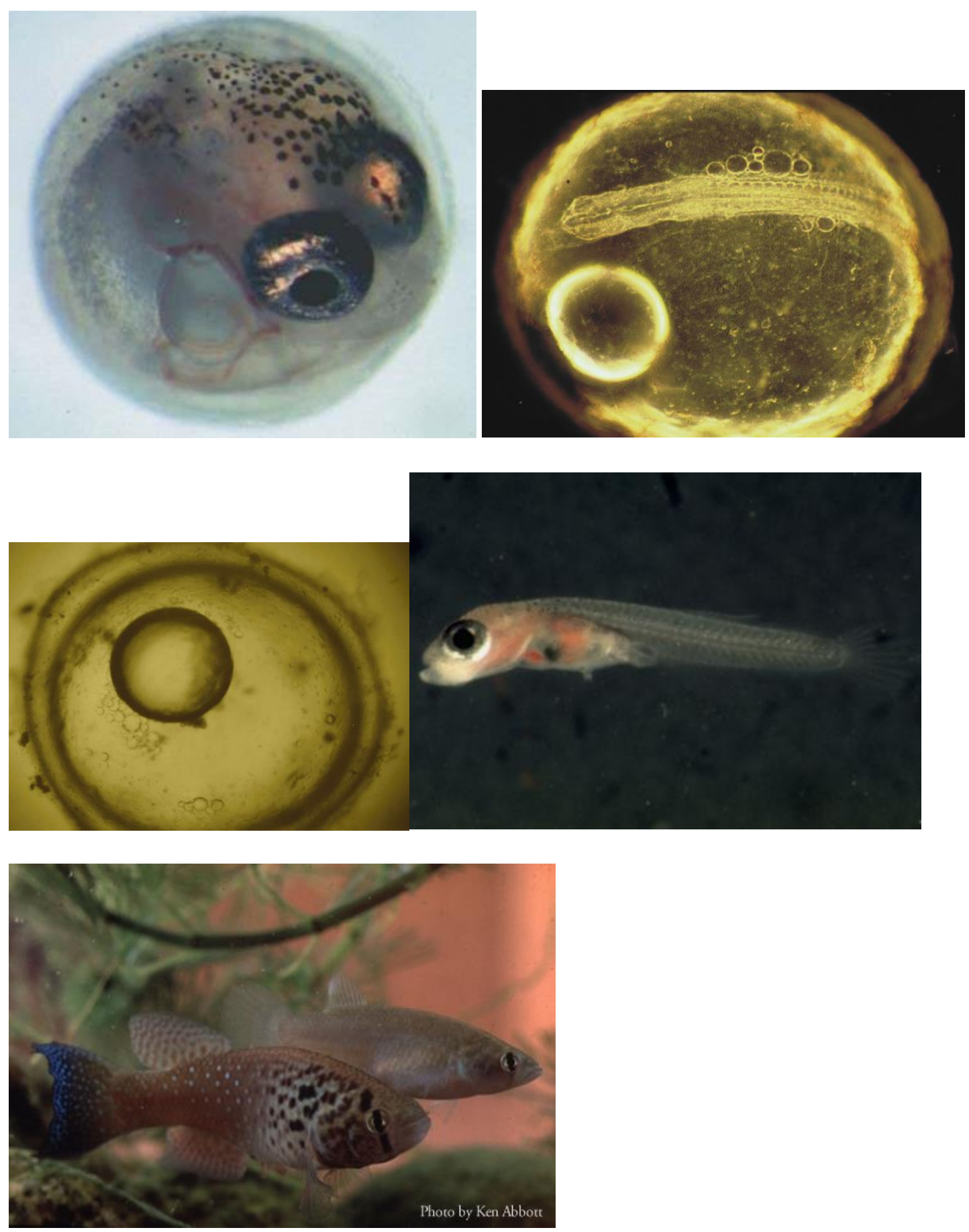
PDF Slides
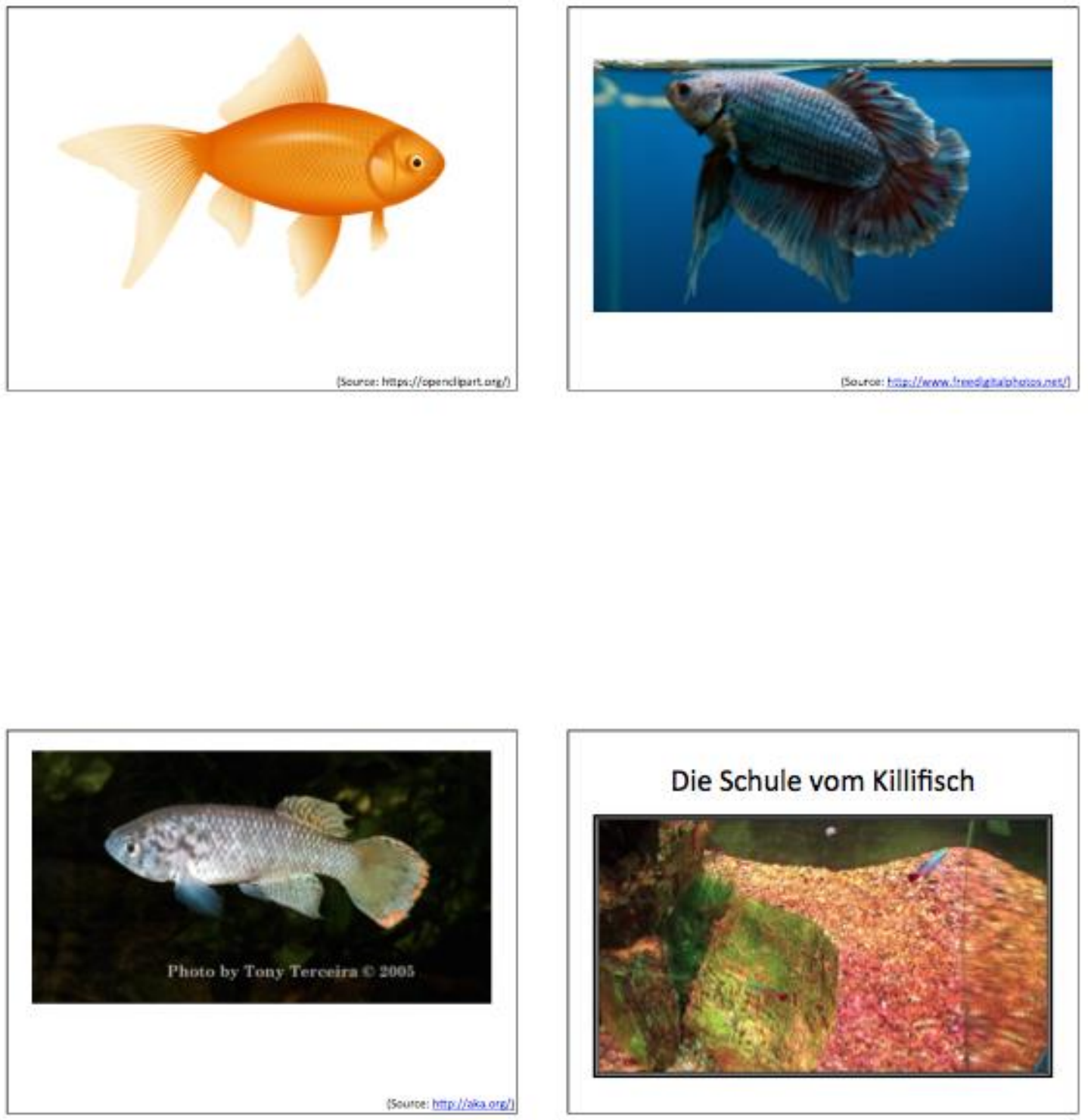


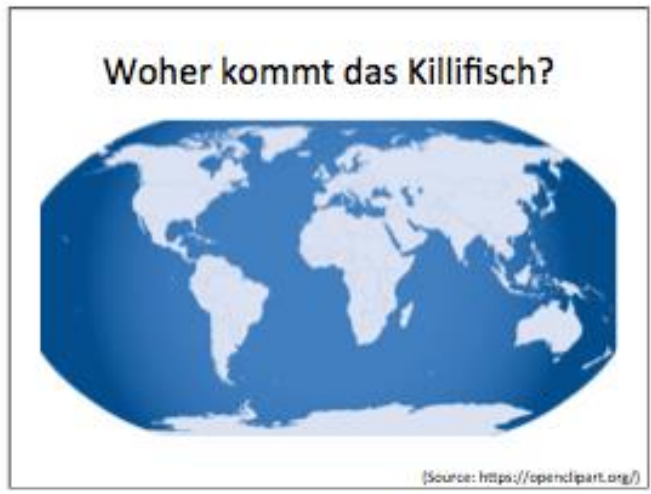

Killifisch aus Südamerika und Afrika
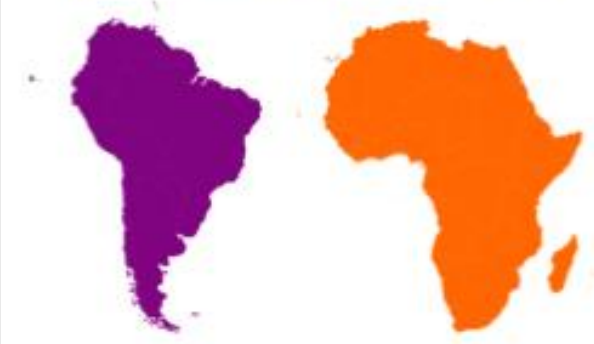

Die Killifische wohnen in
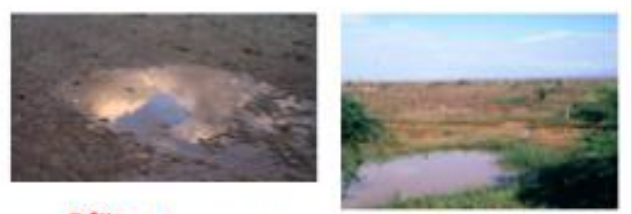

Pfützen

UND

Tümpel

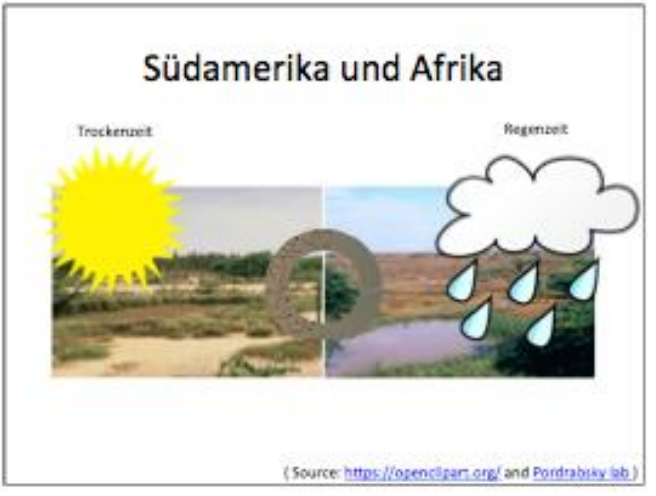




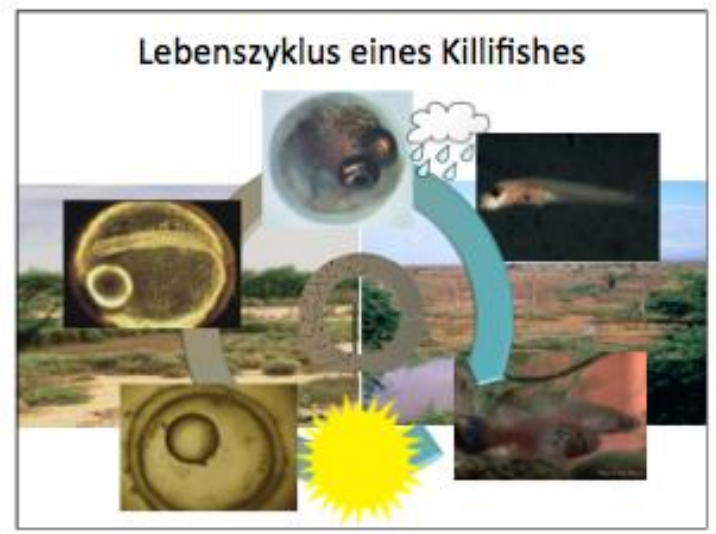




\section{Appendix B: STEM + German Activity, Fahren!}

Grade: 9-12

Proficiency Level: Intermediate Low - High

Goals: Students will use vocabulary specific to transportation and recognize some $3^{\text {rd }}$ person singular regular and irregular verb forms through mathematical modeling.

Students will use numbers and quantities in their answers and use simple mathematical formulas like addition, multiplication, division and subtraction.

Objectives: Students will explore some German-made cars, German geography, and metric system measurements within mathematical models. Students will write simple sentences in the present tense to describe answers to questions. Students will comprehend questions relating to distance and amount.

\begin{tabular}{|c|c|}
\hline STEM Content Standards & Foreign Language Standards \\
\hline $\begin{array}{l}\text { CCSS.MATH.CONTENT.HSN.Q.A.2 } \\
\text { - "Define appropriate quantities for } \\
\text { the purpose of descriptive } \\
\text { modeling" } \\
\text { CCSS.MATH.PRACTICE.MP4 } \\
\text { - } \\
\text { Model with mathematics: "Links } \\
\text { classroom mathematics and } \\
\text { statistics to everyday life, work, } \\
\text { and decision making." }\end{array}$ & $\begin{array}{l}\text { NSFLE } 5 \text { C } \\
\text { Communication: } 1.1,1.2,1.3 ; \\
\text { through oral and written } \\
\text { conversation, interpretation, and } \\
\text { presentations students } \\
\text { communicate information, } \\
\text { concepts, ideas, opinions, and } \\
\text { emotions. } \\
\text { Connections: } 3.1 \text {; reinforce and } \\
\text { further knowledge of other } \\
\text { disciplines through the foreign } \\
\text { language through using } \\
\text { mathematical modeling and } \\
\text { vocabulary for quantities. } \\
\text { Comparisons: Students see what } \\
\text { products (automobile) are } \\
\text { available in the US that are from } \\
\text { Germany. } \\
\text { Communities: Students use } \\
\text { language in school setting. } \\
\text { Intermediate Low/Mid } \\
\text { Intermediate Low learners } \\
\text { should communicate information } \\
\text { through short statements and } \\
\text { discrete sentences. }\end{array}$ \\
\hline
\end{tabular}




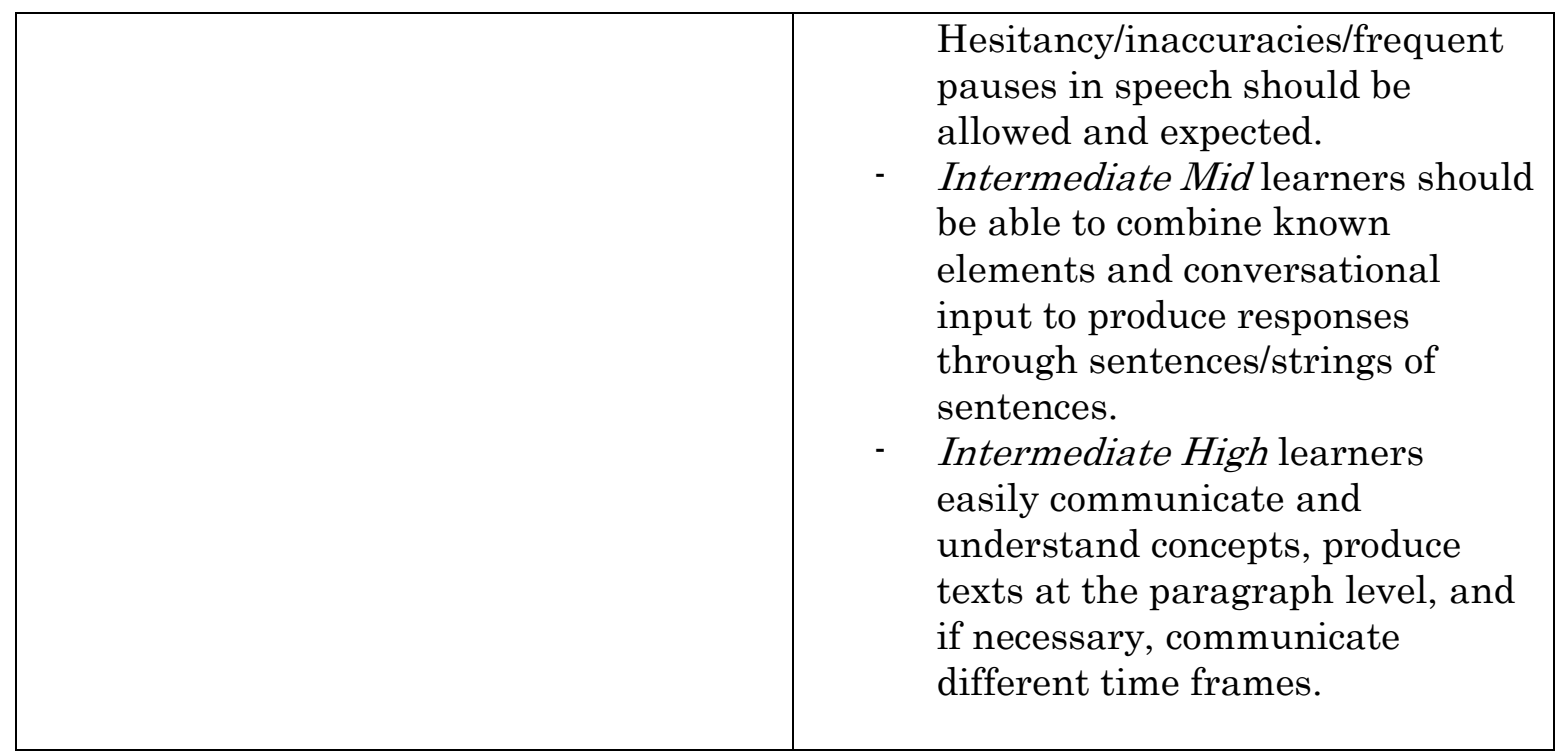




\section{Duration 30 minutes (This task should be implemented during lessons about transportation, an activity to supplement learning Germanys use of the metric system, German products, or any other cultural activity involving technology)}

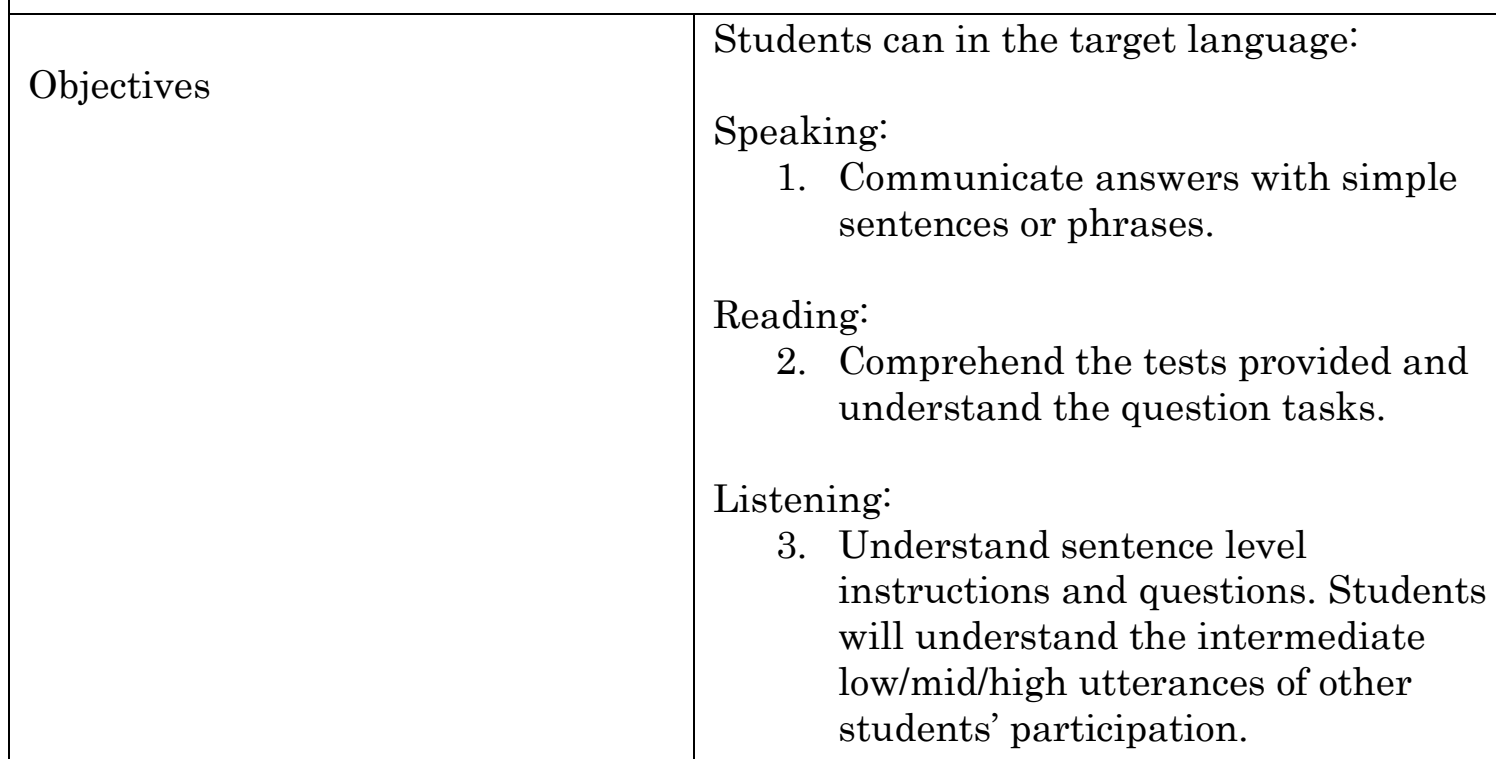

Writing:

4. Write basic sentences in the present tense with moderate errors using the vocabulary from the lesson. For IntHigh Students, if necessary reproduction of different time frames in answers.

Students will comprehend the following STEM discipline content:

5. Mathematical modeling requires realworld use of mathematical concepts: measurements, data, number operations, quantity, and algebraic thinking.

Task

Teacher may warm up with questions relating to the model handouts.

- Benutzen die Deutschen Gallone oder Liter?

- Wo ist (z.B. Hamburg)/ Wie weit ist 


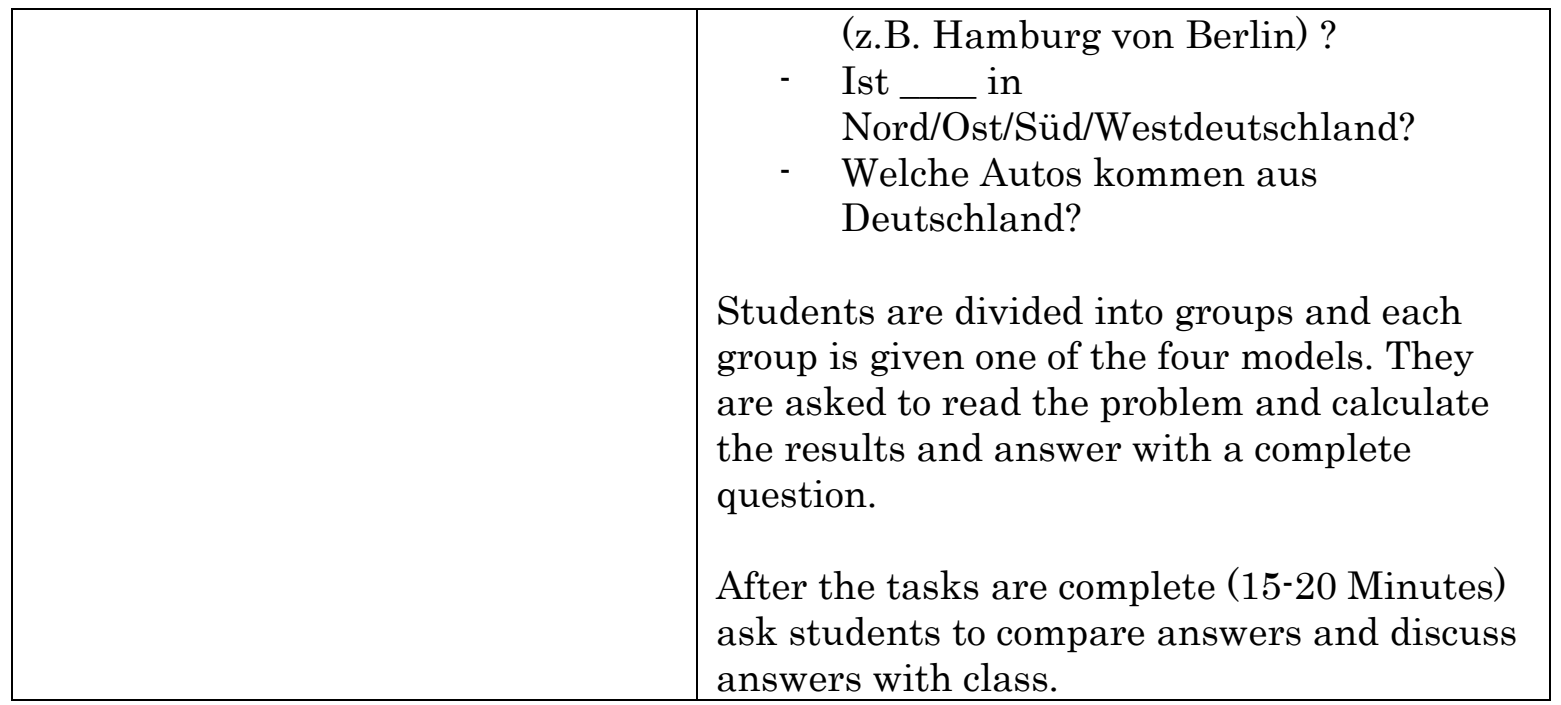

Sources for information on the vehicles come from their manufacturers websites.

Opal Adam:

http://www.opel.de/fahrzeuge/modelle/personenwagen/adam/index.html

BMW 1er 3-Türer: http://www.bmw.de/de/neufahrzeuge/1er/3-

tuerer/2012/start.html

Volkswagen Golf Cabriolet:

http://www.volkswagen.de/de/models/golf cabriolet.html 
Sie machen eine Reise mit Freunden!

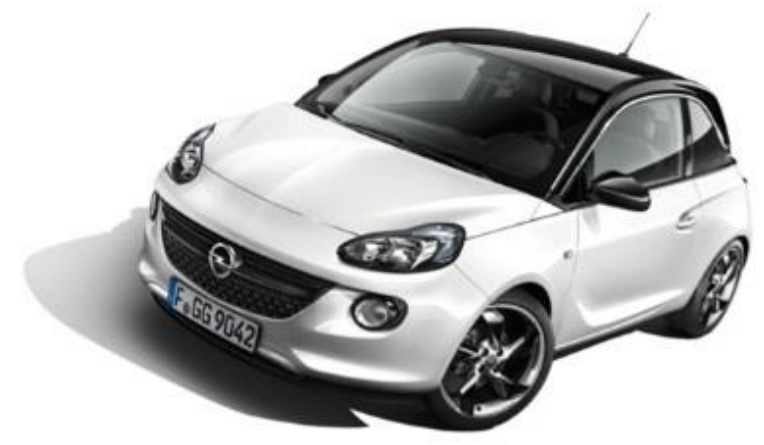

A

(B) Hamburg
2 Stunden 51 Minuten

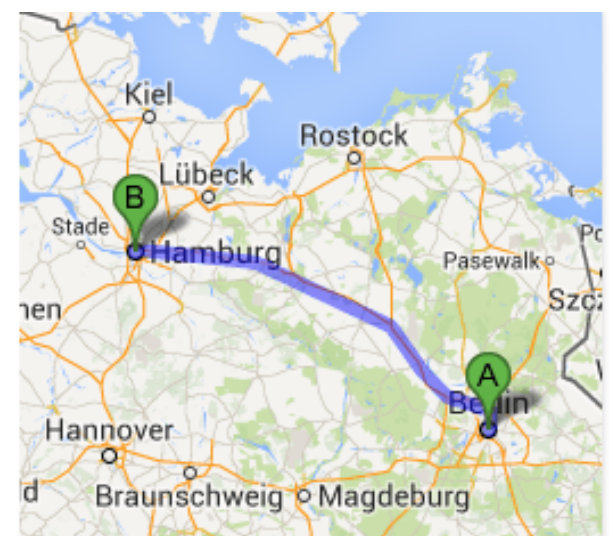

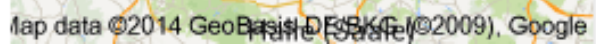

Sie fahren zusammen von Hamburg nach Berlin mit dem Auto. Berlin ist $289 \mathrm{~km}$ von Hamburg. Heute kostet Benzin €0,75 pro Liter in Hamburg. Ihr Auto wurde vor der Reise voll getankt und Sie fahren ein Opal ADAM und der Tank halt 38 Liter. Die Opal ADAM braucht ungefähr 6,9 Liter Benzin pro 100 Kilometer.

1. Vielviel kostet ein voller Tank Benzin?

2. Wie oft müssen Sie tanken?

3. Wer zahlt?

4. Wieviele Kilometer pro Stunde $(\mathrm{Km} / \mathrm{h})$ müssen Sie fahren, um in zwei Stunden und 51 Minuten in Hamburg anzukommen? 
Sie machen eine Reise mit Freunden!

(A)

Stuttgart

2 Stunden 4 Minuten

Bei aktueller Verkehrslage: 2 Stunden 30 Minuten

(B) Frankfurt am Main गlenz 3 Bad Homburg

(5) vor de $B$ öhe
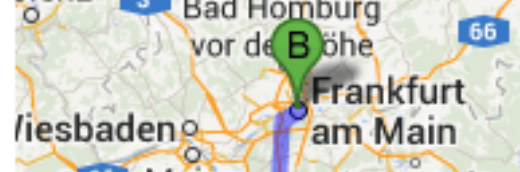

61 Mainz o Innenstadt

Darmstadt

63

oworms

650 OMannheim
Heidelberg

$204,4 \mathrm{~km}$

icken

65

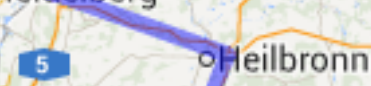

Karlsruhe o Durlach den-Badeno Pforzheim of Stuttgart

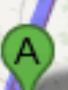
den-Baden 14 GeoBasis-DEJBKG (@2009), Google

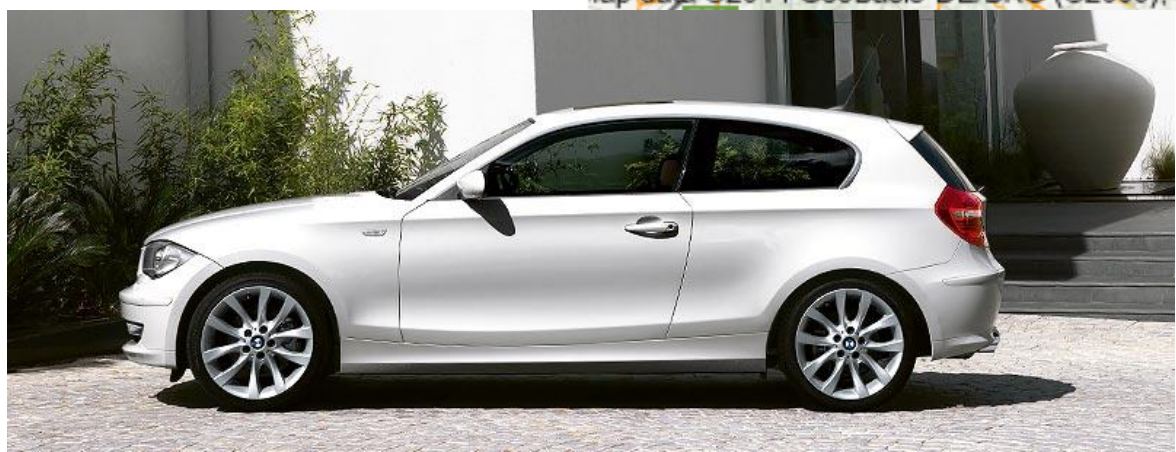

Sie fahren zusammen von Stuttgart nach Frankfurt mit dem Auto. Frankfurt ist $204 \mathrm{~km}$ von Stuttgart. Heute kostet Benzin $€ 0,63$ pro Liter in Stuttgart. Ihr Auto wurde vor der Reise voll getankt und Sie fahren einen $B M W$ 1er 3-Türer und der Tank halt 52 Liter. Die BMW 1er 3-Türer braucht ungefähr 3,8 Liter Benzin pro 100 Kilometer.

1. Vielviel kostet ein voller Tank Benzin?

2. Wie oft müssen Sie tanken?

3. Wer zahlt?

4. Wieviele Kilometer pro Stunde $(\mathrm{Km} / \mathrm{h})$ müssen Sie fahren, um in zwei Stunden und vier Minuten in Frankfurt anzukommen? 
Sie machen eine Reise mit Freunden!

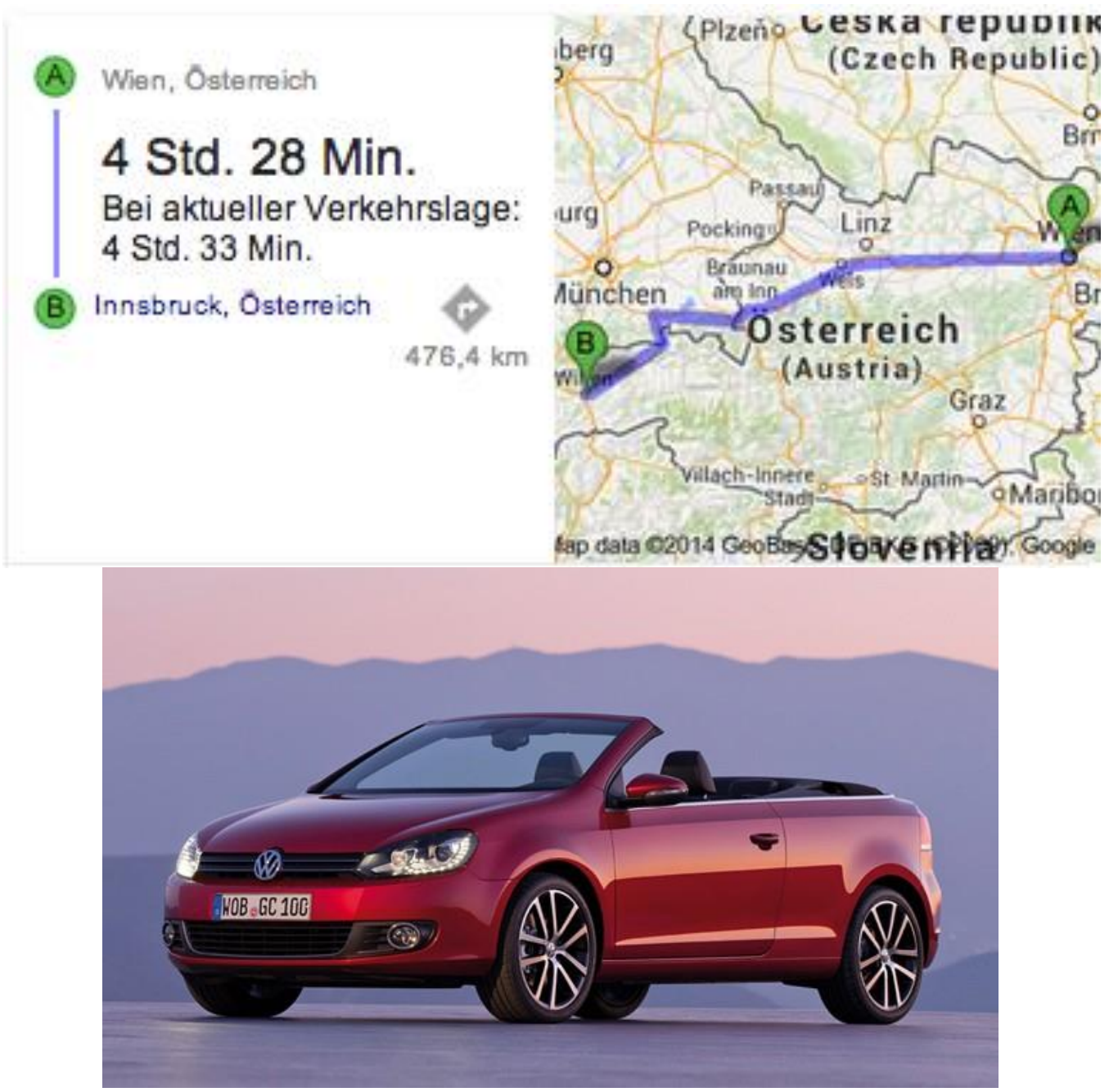

Sie fahren zusammen von Wien nach Innsbruck mit dem Auto. Wien ist $476 \mathrm{~km}$ von Innsbruck. Heute kostet Benzin €1,30 pro Liter in Wien. Ihr Auto wurde vor der Reise voll getankt und Sie fahren ein Volkswagen Golf Cabriolet und der Tank halt 55 Liter. Die Volkswagen Golf Cabriolet braucht ungefähr 5,9 Liter Benzin pro 100 Kilometer.

1. Vielviel kostet ein voller Tank Benzin?

2. Wie oft müssen Sie tanken?

3. Wer zahlt?

4. Wieviele Kilometer pro Stunde $(\mathrm{Km} / \mathrm{h})$ müssen Sie fahren, um in vier Stunden und 23 Minuten in Innsbruck anzukommen? 
Sie machen eine Reise mit Freunden!

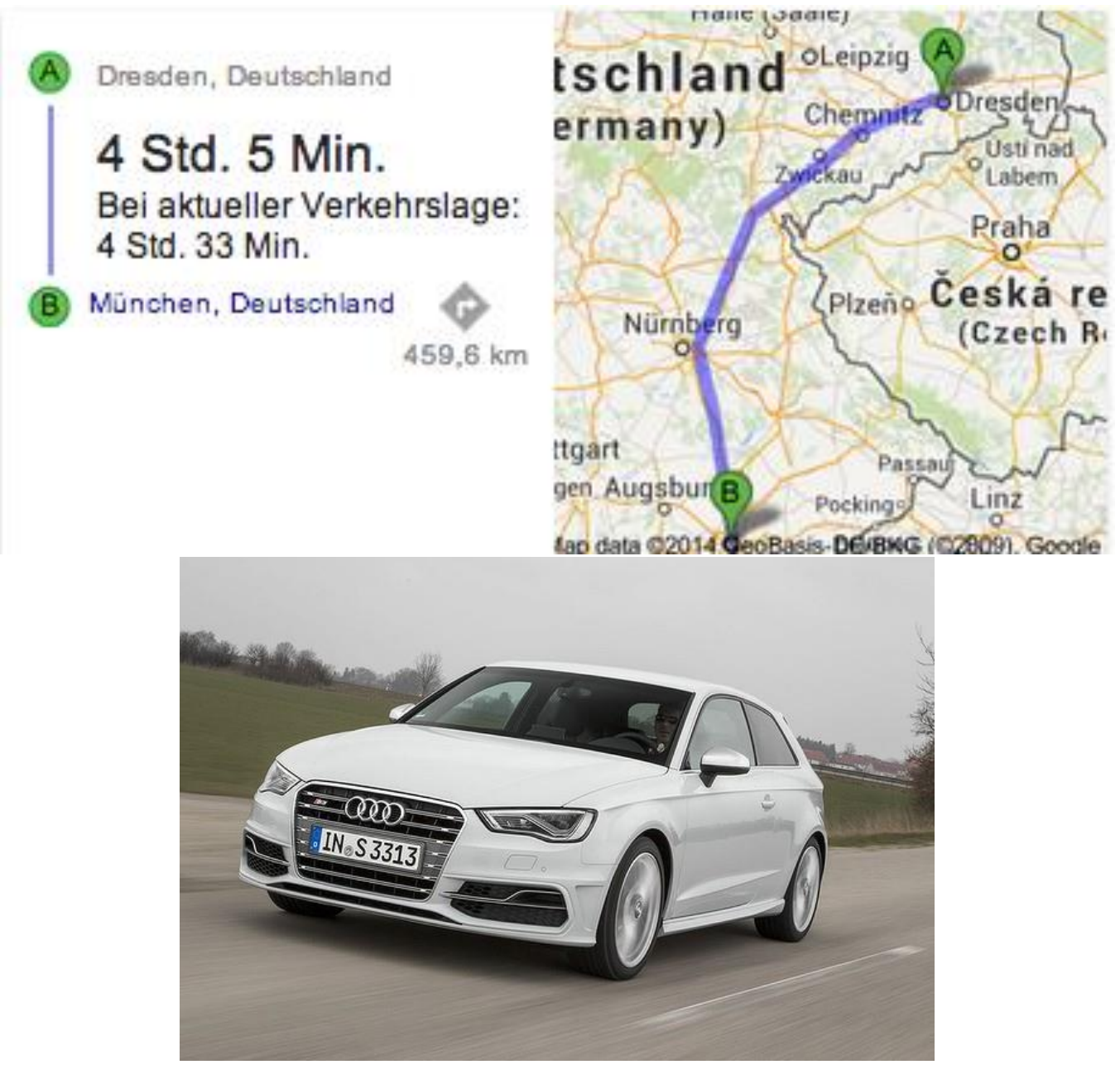

Sie fahren zusammen von München nach Frankfurt mit dem Auto. München ist $460 \mathrm{~km}$ von Dresden. Heute kostet Benzin $€ 1,45$ pro Liter in München. Ihr Auto wurde vor der Reise voll getankt und Sie fahren einen BMW 1er 3-Türer und der Tank halt 52 Liter. Die BMW 1er 3-Türer braucht ungefähr 3,8 Liter Benzin pro 100 Kilometer.

1. Vielviel kostet ein voller Tank Benzin?

2. Wie oft müssen Sie tanken?

3. Wer zahlt?

4. Wieviele Kilometer pro Stunde $(\mathrm{Km} / \mathrm{h})$ müssen Sie fahren, um in vier Stunden und sechs Minuten in Dresden anzukommen? 


\section{Appendix C: STEM + German Module, Energiequellen}

Grade: 9-12

Proficiency Level: Intermediate Low

Goals: Using the power point provided and classroom discussion and presentation students will understand various major forms of energy consumption. They will discuss their daily personal decisions that are either ecofriendly or sustainable and what they and their community can do better. Students will create informative pamphlets for presentation about energy sources.

Objectives: Students will use the new vocabulary to describe the decisions they make that impact their environment. They will be able to describe data represented on a graph in the target language.

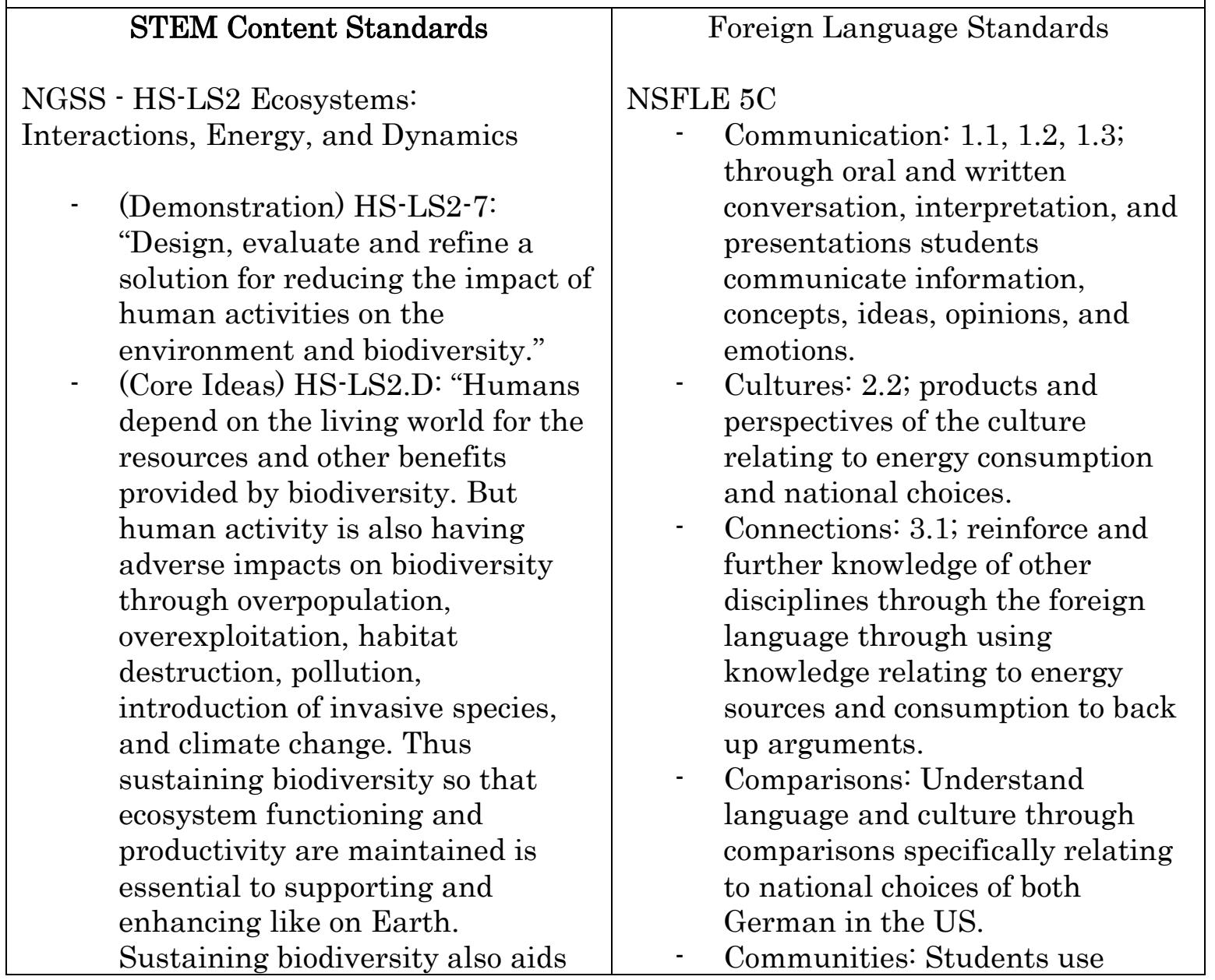




\begin{tabular}{|c|c|}
\hline $\begin{array}{l}\text { humanity by preserving } \\
\text { landscapes of recreational or } \\
\text { inspirational value." } \\
\text { CCSS.MATH.CONTENT.HSN.Q.A.2 } \\
\text { "Define appropriate quantities for } \\
\text { the purpose of descriptive } \\
\text { modeling" } \\
\text { Standards for Technological Literacy } \\
\text { - } 4 \text { - Technology and Society; } \\
\text { 9-12.I "Making decisions } \\
\text { about the use of } \\
\text { Technology involves } \\
\text { weighing the trade-offs } \\
\text { between the positive and } \\
\text { negative effects." } \\
\text { - Effects on the Environment } \\
\text { 9-12.L "Decisions } \\
\text { regarding the } \\
\text { implementation of } \\
\text { technologies involve } \\
\text { weighing of trade-offs } \\
\text { between predicted positive } \\
\text { and negative effects on the } \\
\text { environment." } \\
\text { - } \\
\text { 9-12.M "Energy resources } \\
\text { can be renewable or } \\
\text { nonrenewable." }\end{array}$ & $\begin{array}{l}\text { language in school setting. } \\
\text { Intermediate Low/Mid } \\
\text { - Intermediate Low learners } \\
\text { should communicate information } \\
\text { through short statements and } \\
\text { discrete sentences. } \\
\text { Hesitancy/inaccuracies/frequent } \\
\text { pauses in speech should be } \\
\text { allowed and expected. } \\
\text { Intermediate Mid learners should } \\
\text { be able to combine known } \\
\text { elements and conversational } \\
\text { input to produce responses } \\
\text { through sentences/strings of } \\
\text { sentences. }\end{array}$ \\
\hline
\end{tabular}




\section{Duration 90 minutes (can be divided into 3 separate 30 minute lessons; Pre-Task - Introduction, Pre-Task - Discussion, Task and Post-Task)}

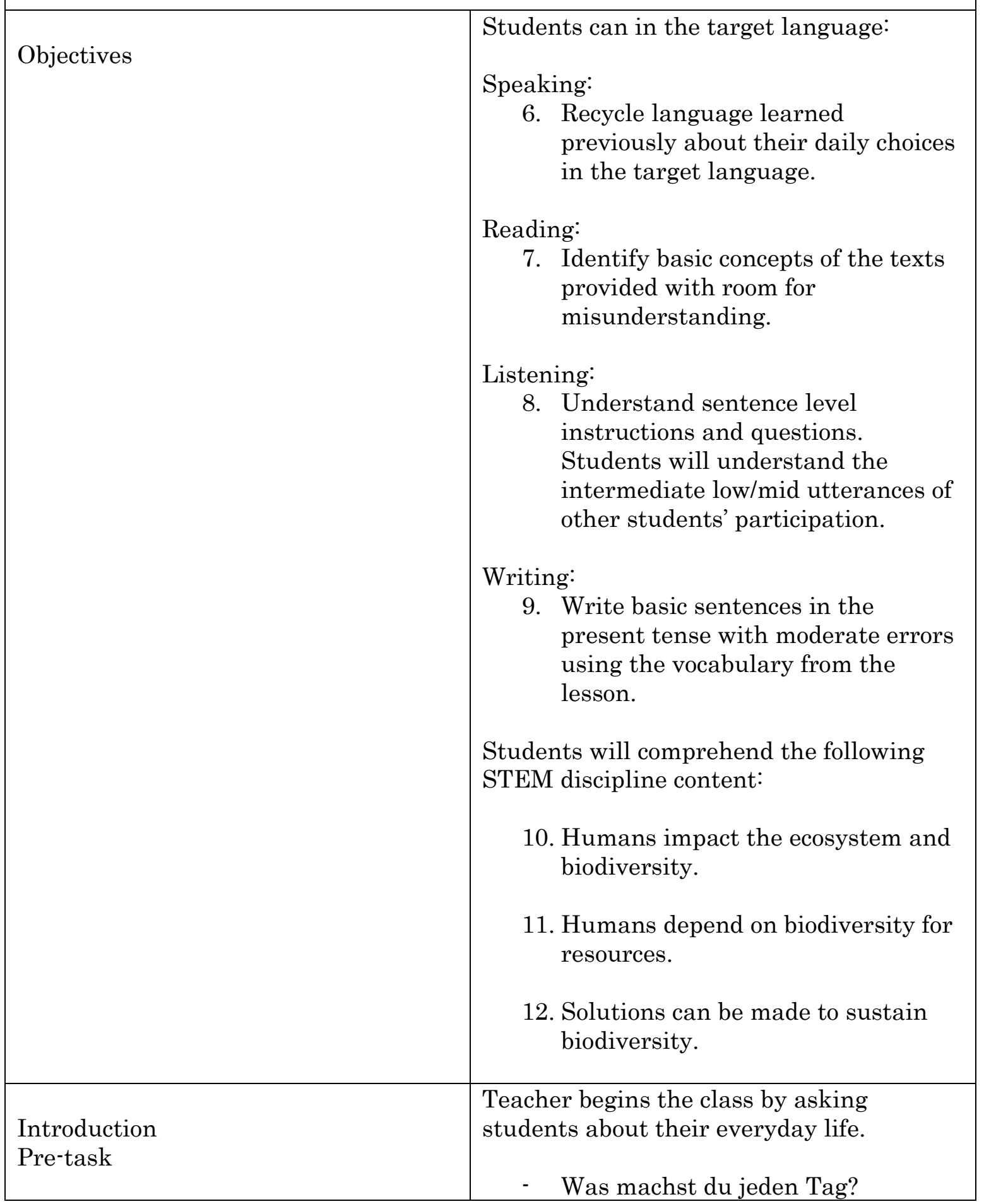


After discussion complete or dying down, teacher begins introducing topic with additional discussion. Students are allowed to gather information, vocab that help with discussion. TPR/visual aids can be used for assistance in comprehension. PPT slide one can be used as an intro to questions.

- Wie oft und wie lange duscht/badest du dich?

- Wo kaufst du deine Lebensmittel? Woher kommt das Essen?

- Was machst du mit deinem Müll?

- Wie kommst du zur Schule an?

- Machst du die Lichter immer aus?

Teacher introduces concept of how we affect the world we live in through classroom discussion.

- Wo kommt das Wasser, damit wir duschen können?

- Wohin geht das Plastik Müll, wenn wir nicht recyceln?

- Was ist das Problem, wenn wir jeden Tag mit einem Auto zur Schule fahren?

- Was ist das Problem, wenn wir die Lichter nicht ausmachen?

- Kommt dein Lebensmittel alles aus den USA? Und wie viel kommt aus (home city/state)? 


\begin{tabular}{|c|c|}
\hline Pre-task & 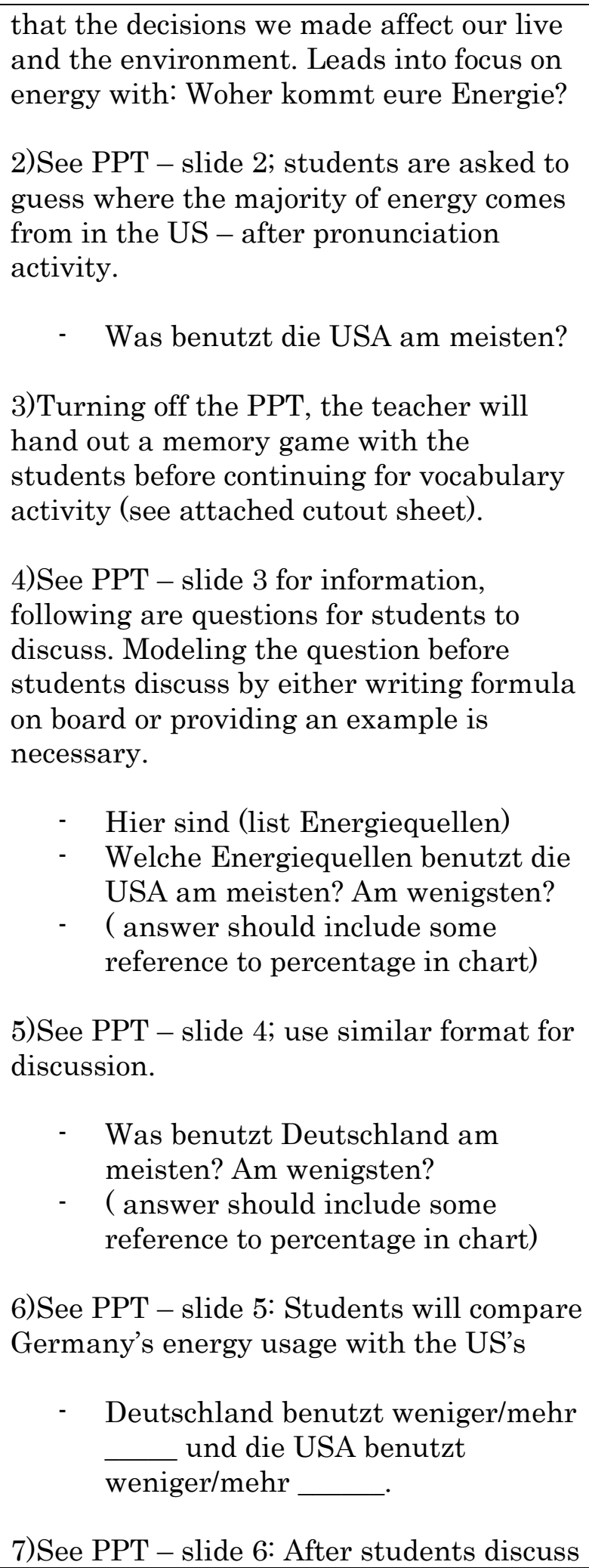 \\
\hline
\end{tabular}




\begin{tabular}{|c|c|}
\hline & $\begin{array}{l}\text { slide with partners, students will be asked } \\
\text { to express their opinions. } \\
\text { - Was ist die beste } \\
\text { umweltfreundlichste } \\
\text { Energiequelle? } \\
\text { - Was sollen Menschen weniger } \\
\text { benutzen? } \\
\text { 8) See PPT - slide 7-19: Student learn } \\
\text { about various impacts of various sources of } \\
\text { energy consumption. } \\
\text { - Everyone is given a vocab/note } \\
\text { taking page (see attached } \\
\text { materials). } \\
\text { Ask students after presenting each } \\
\text { slide to repeat and discuss: Was } \\
\text { sind die Problemen mit } \\
\text { (Enegiequelle)? Wer braucht mehr, } \\
\text { Deutschland oder die USA? }\end{array}$ \\
\hline $\begin{array}{l}\text { Creating a Pamphlet } \\
\text { Task }\end{array}$ & $\begin{array}{l}\text { 9)See PPT - slide 20: Students are } \\
\text { presented a situation in which they must } \\
\text { make a pamphlet to the US explaining the } \\
\text { necessity of alternative forms of Energy } \\
\text { and the environmental problems with the } \\
\text { current sources of energy of today. } \\
\text { Students work in groups of 2-4 to create a } \\
\text { pamphlet that uses information from the } \\
\text { lesson. Use printouts of pamphlet. }\end{array}$ \\
\hline $\begin{array}{l}\text { Presentation } \\
\text { Post Task }\end{array}$ & $\begin{array}{l}\text { Groups are asked to present their } \\
\text { information with other groups as if they } \\
\text { were real busineses. }\end{array}$ \\
\hline
\end{tabular}

Background information:

Information For USA's energy: http://www.eia.gov/totalenergy/data/monthly/pdf/flow/primary_energy.pdf 
Inforamtion For Germany's Energy:

https://www.destatis.de/DE/ZahlenFakten/Wirtschaftsbereiche/Energie/Erzeugung/T abellen/Bruttostromerzeugung.html

Information about the effect of energy on the environment:

http://www.epa.gov/cleanenergy/energy-and-you/affect/index.html

This is a cutout for a memory game.

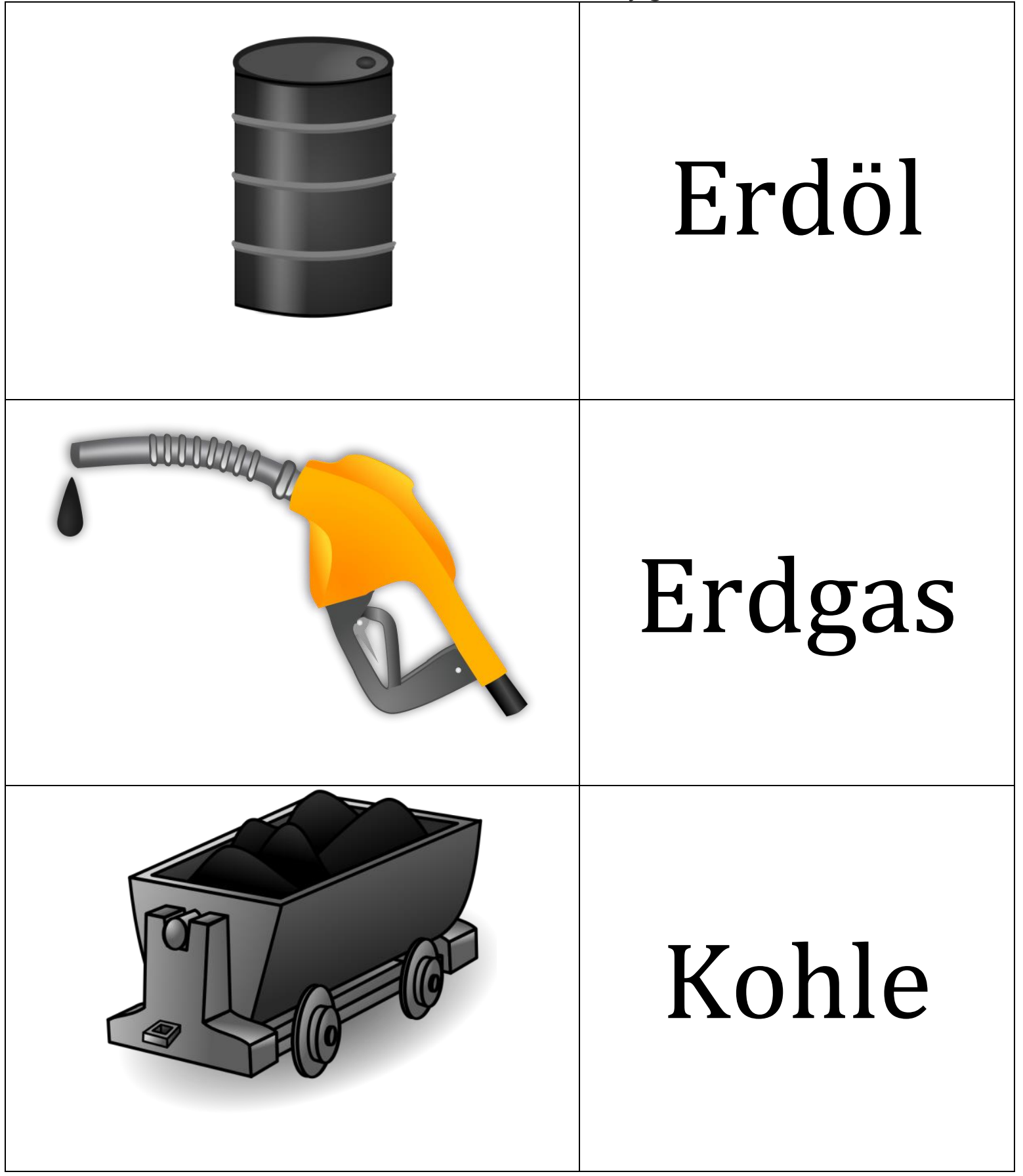




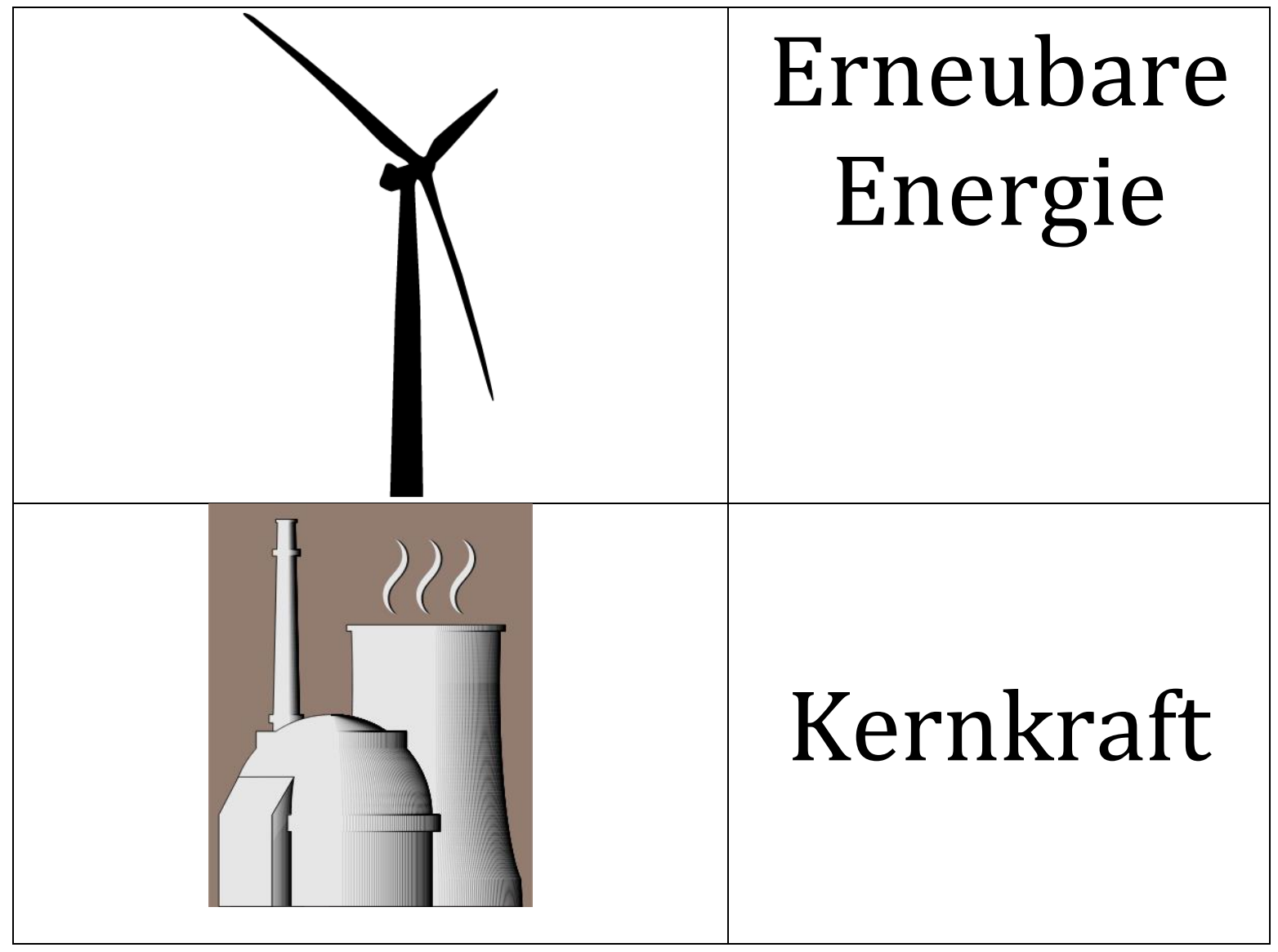




\begin{tabular}{|l|l|}
\hline \multicolumn{2}{|c|}{ Energiequellen Notizen } \\
\hline Information über die USA & \\
\hline Information über Deutschland & \\
\hline Kohle & \\
\hline Kernkraft & \\
\hline Erdöl & \\
\hline Erdgas & \\
\hline Wasserkraft & \\
\hline Solarkraft & \\
\hline
\end{tabular}



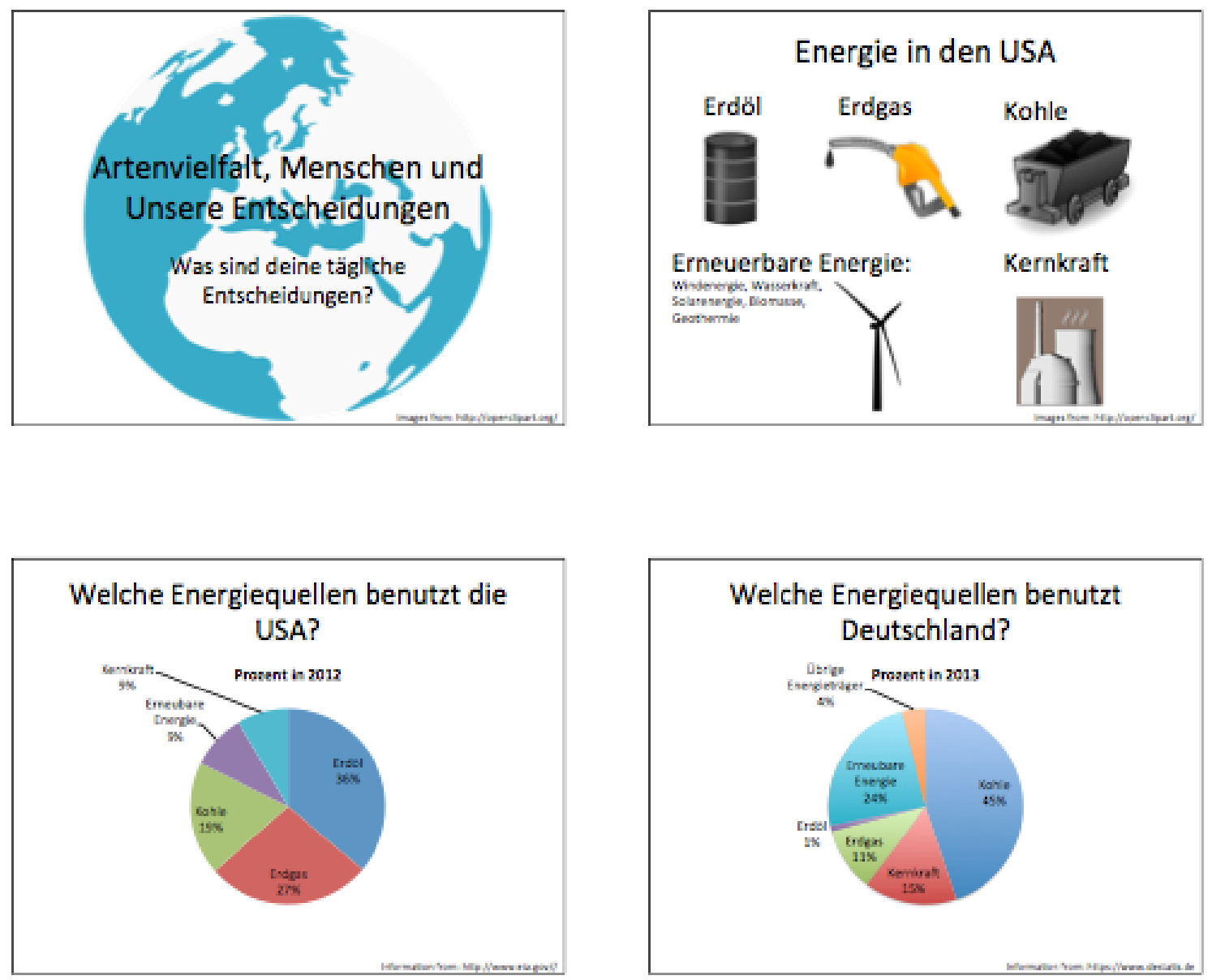

Welche Energiequellen benutzt Deutschland?

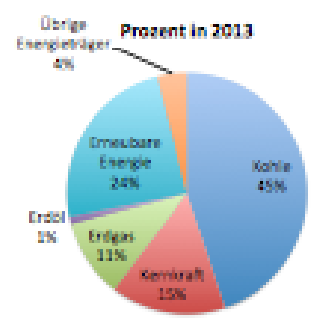

\section{Deutschland und die USA}
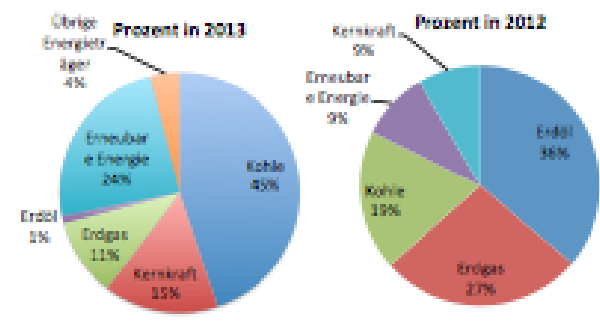

Deutschland

USA

Die Energiequellen: Was glaubst du?

- Was ist die beste umweltfreundlichste Energiequelle?

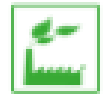

- Was verschmutzt die Umwelt?

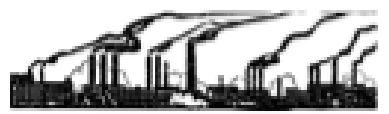



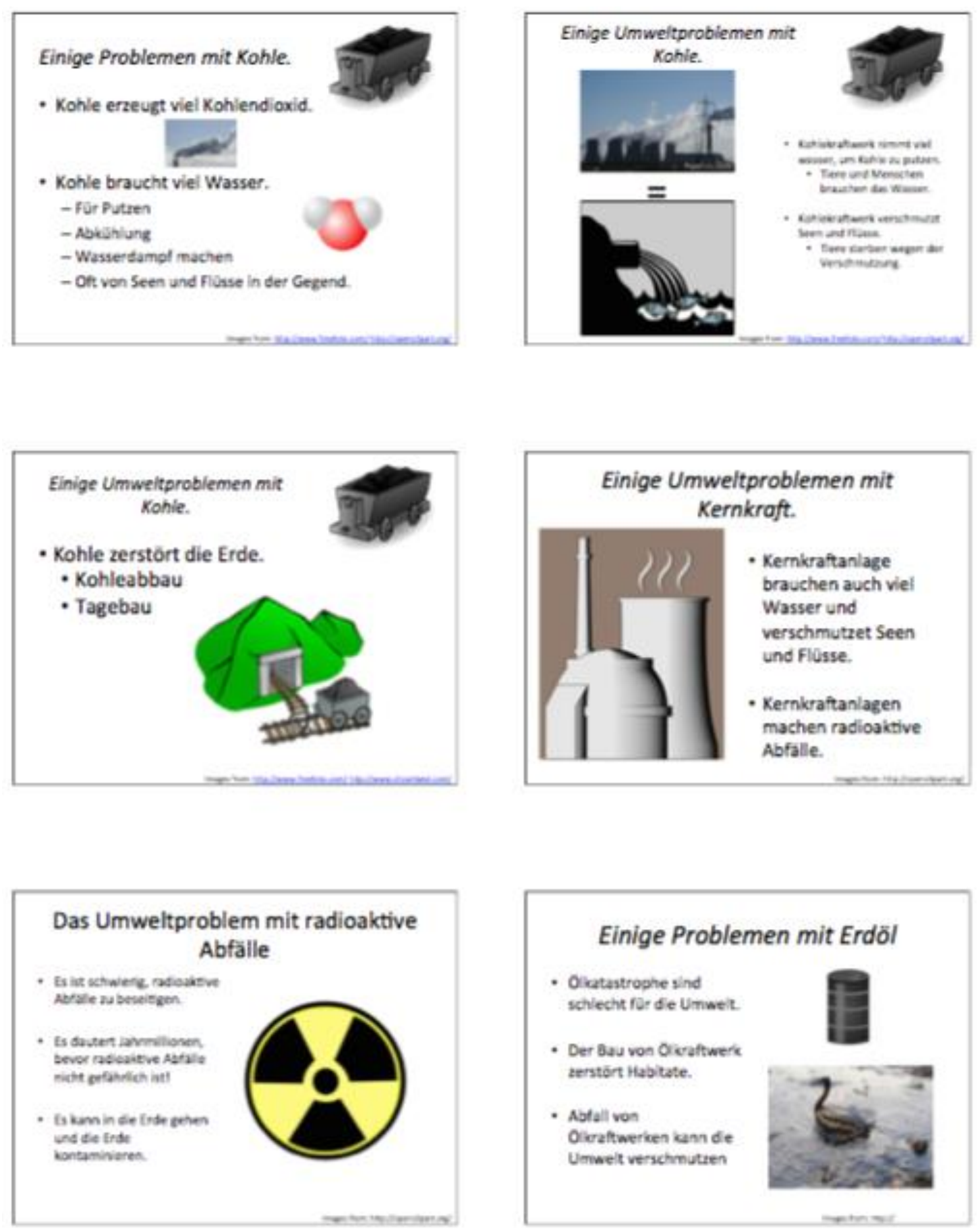

\section{Einige Problemen mit Erdöl}

- Oratastrophesind schiecht for de Umweit.

- Der Bau von Oivaftwerk zerstört Habitate.

- Abtall voa

Oreraftwerken kann de Umwelt verschmutien

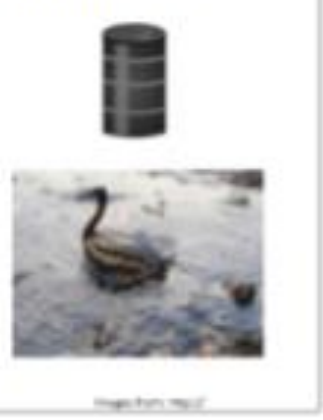




\section{Einige Umweltproblemen mit Erdöl}

- Erdól erzeugt auch vie/ Kohlend axid und braucht viel Wasser für Abkühlung.

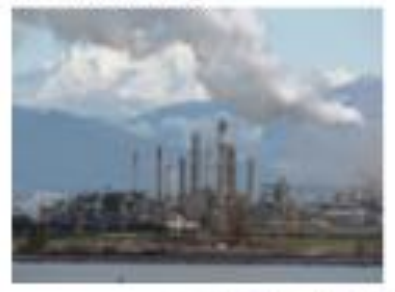

\section{Gibt es Umweltproblemen mit erneuerbore Energie?}

- Wasserkraft braucht Damme.

- Dámme zerstören

Wassertiere,

hauptsatzich Lachs.

- Dămme kann Land uberfluten, deswegen sterben Habitate in dec Gegend.

\section{Einige Umweitproblemen mit Erdgas}

- Erdgaspewinnung zerstört die Umwelt.

- Erdgaskessel erzeugt Wasserversthmutzung.

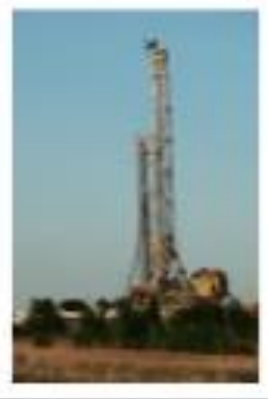

\section{Gibt es Umweltproblemen mit erneuerbare Energie?}

- Solarkraft braucht viel Land und kann

Habitate storen.

- Solarkraft braucht kein Wasser und erzeugt kein Abfalle.

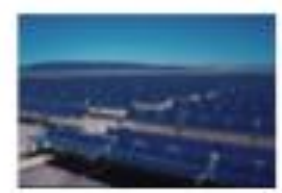

\section{Gibt es Umweltproblemen mit erneuerbare Energie?}

- Geothermie korrmt von Ger Heizung der Erde. Die erzeust Wasserdampt.

- Geothermie braucht Wasser von unter der Erde bnd von anderen

Gewâsser:

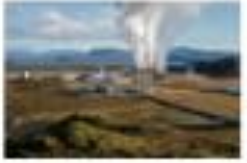

- Land kann sinken, wern

das Wasser von unter der

Erde nicht zurückgezeben

ist
Gibt es Umweltproblemen mit erneuerbare Energie?

- Biomasse erzeugt ein

bisschen Kohlendioxid.

- Biomasse braucht Wasser und auch viel Land.

- Auch nicht gut fur die Mabitate in der Gegend

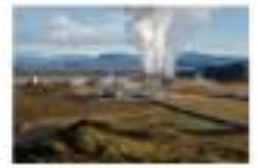


Gibt es Umweltproblemen mit erneuerbare Energie?

- Windenergie braucht Land aber Windenergie kann auch auf dem Ozean sein.

- Windenergie macht asthetische Problemen (laut) und Windenergie schadet manchmal võgel.

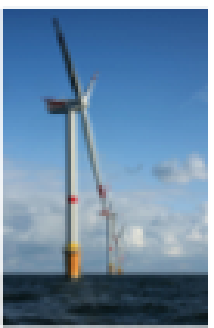

\section{Du arbeitest für eine erneubare} Energiefirma in Deutschland

- Du verkaufst Solarzellenplatten und Windrăder.

- Du musst ein Informationsblatt über Energiequellen fúr die USA machen!

- Enzăhl was besser für Menschen, Tiere und die Umwelt ist und warum!

- Mach Emplehlungen! Warum sollen die USA ihre Produkte kaufen! 